\title{
التكوين المعرفى فى مسرح الطفل : \\ مسرح صلاح جاهين نموذجاً
}

\section{*. دانل الملمى السعيل}

\author{
ملخص البحث
}

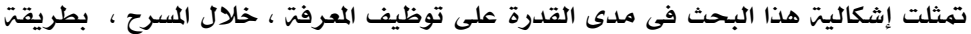

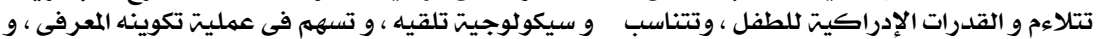

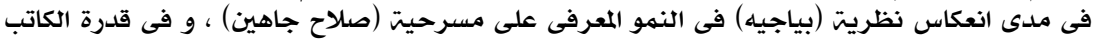

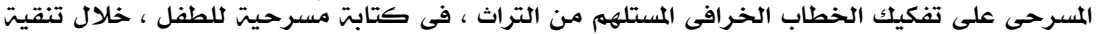

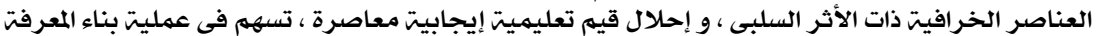

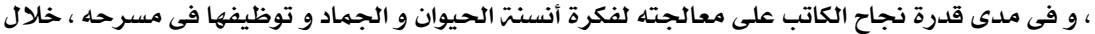

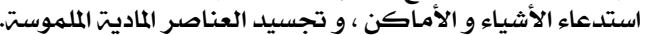

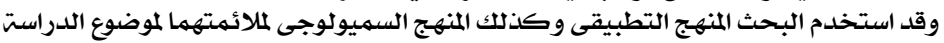
و قد ناقث البحث المحاور الآتيت :

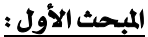

• نظريت (بياجيه) فى النمو المعرفى و قراءات الباحثين حولها.

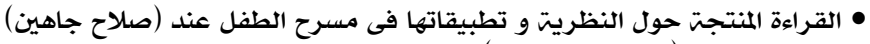

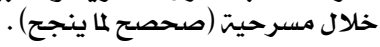

$$
\begin{aligned}
& \text { • دلالات التشابك بين التراث و الحداثت فى (صحصح لما ينجح) . } \\
& \text { • البناء الدرامى و دوره فى تكوين البناء المعرفى . }
\end{aligned}
$$

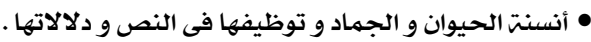

المبحث الثانى:

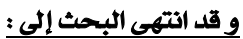

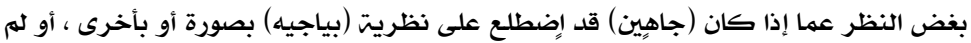

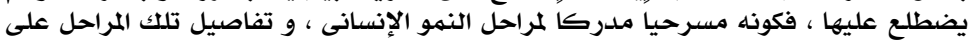

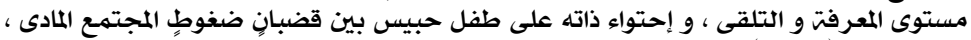

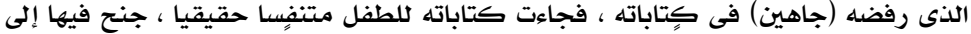

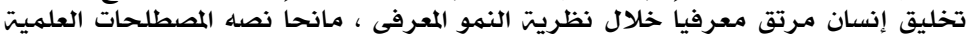

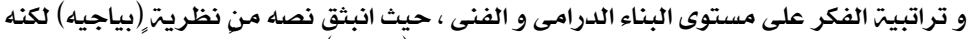

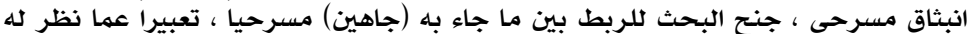

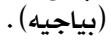

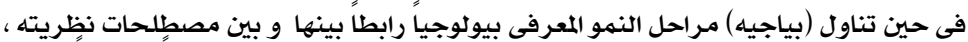

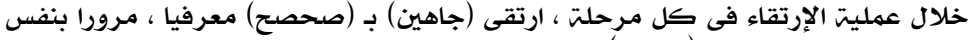

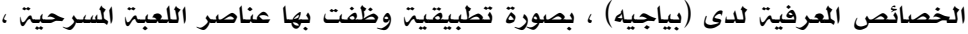

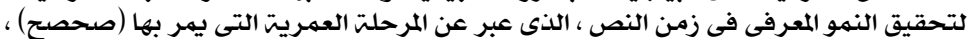

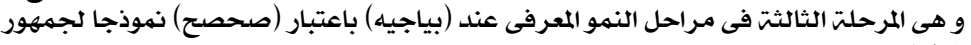


انطلق إجاهين) من الصِور التى تفصح عن كفاءة الطفل الذهنيت فى النظريت ، مجسداً إياها

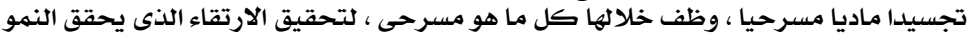
المعرفى (2)

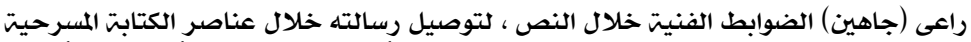

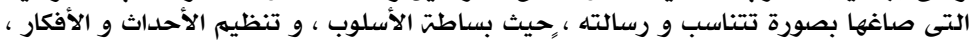

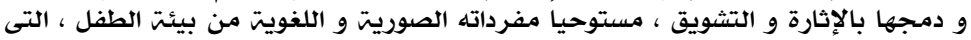

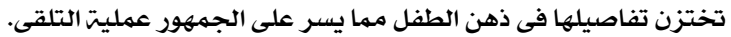

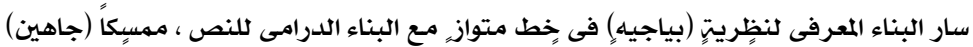

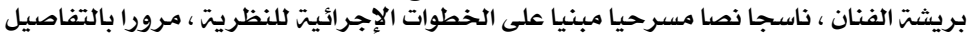

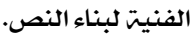

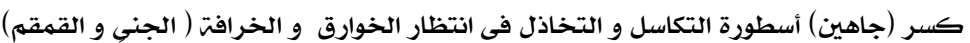

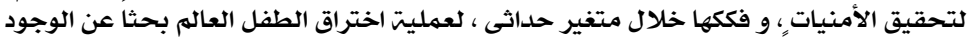

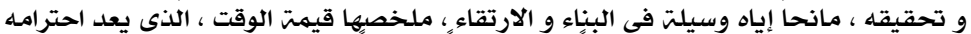

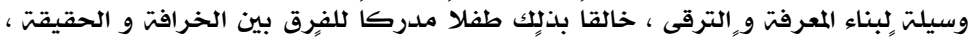

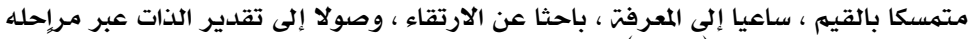

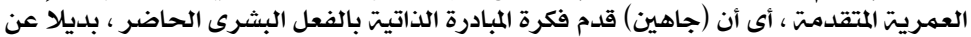

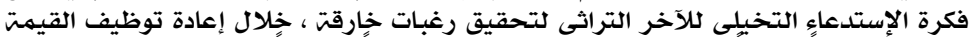

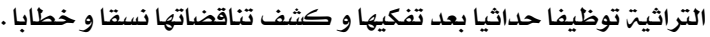

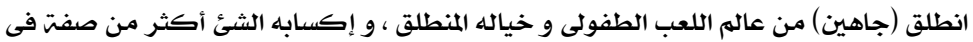

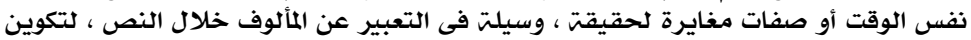

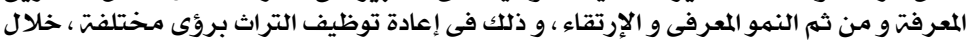

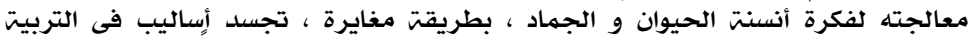

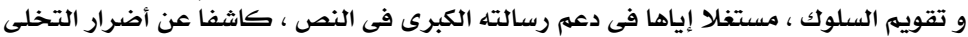

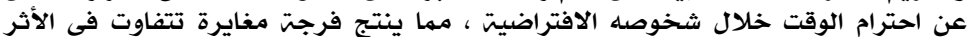

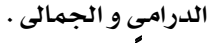

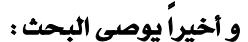

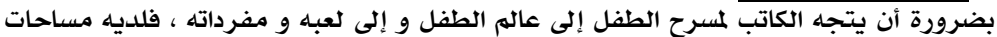

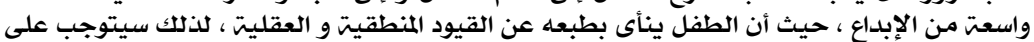

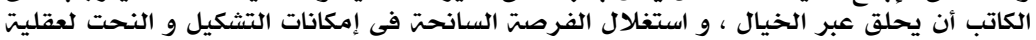

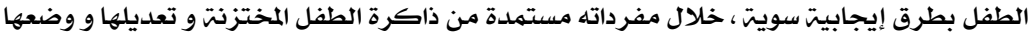

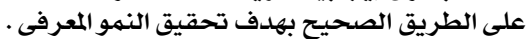




\section{Cognitive Formation in Child Theatre \\ : Salah Jahins Theatre as a Model \\ Abstract}

The problem of this research is represented as the a bility to employ Knowledge in a way that suits the cognitive capabilities of an audience of children with theatrical artistry that is convenient to child psychology that amuses and refines negative behavior; that contributes to the process of cognitive formation ,to the direction of the values of civil society to the reflection of Piaget's theory of cognitive Development on Salah Jahine's play to the ability of a playwright to break down mythical speech inspired by folklore, to write a play for children through refining negative mythical elements and using positive contemporary educational ralues that contribute to the process of knowledge formation and the playwright's ability to process the idea of personifying animals and inanimate objects and employing them in his theatre by invoking object and places and personifying tangible physical elements. The researcher has used applied and Semiological Curricula for their convenience to the study.

\section{الهقدمت المقا}

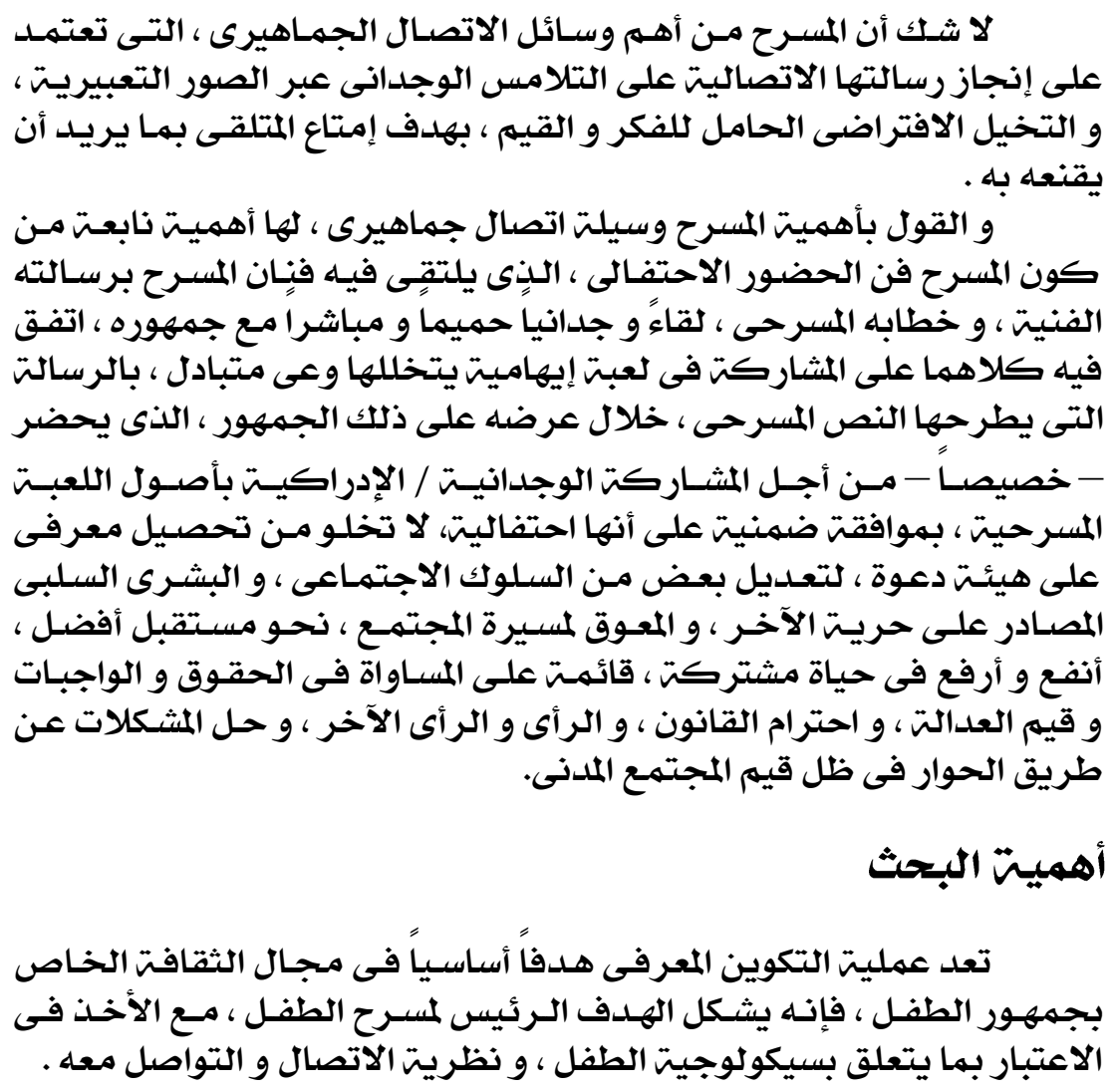




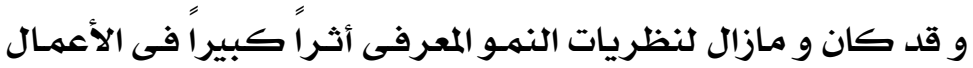

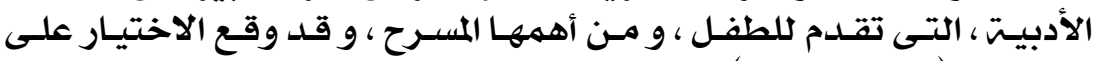

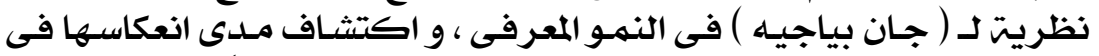

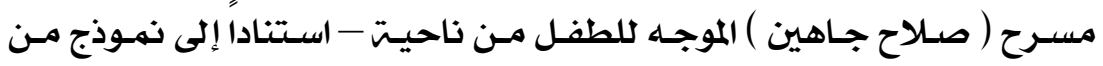

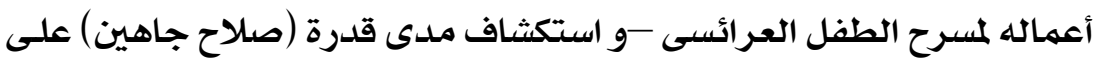

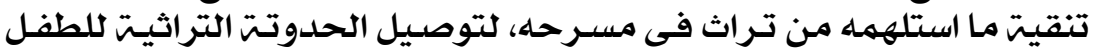

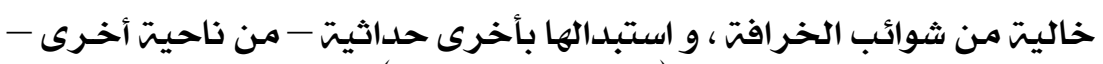

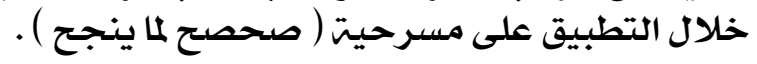

\section{إشاليت البحث}

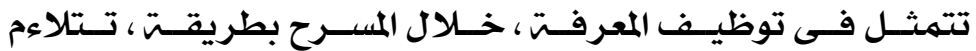

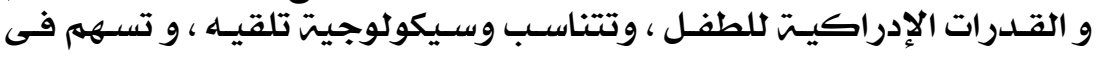

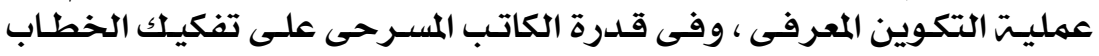

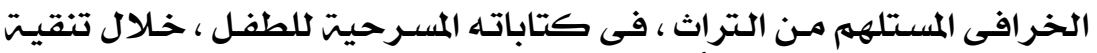

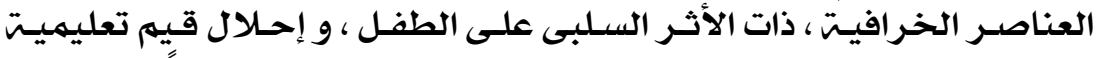

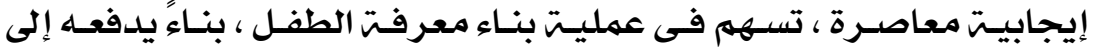

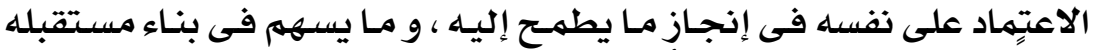

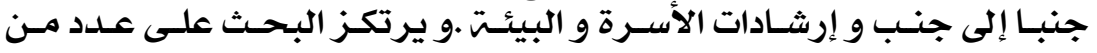

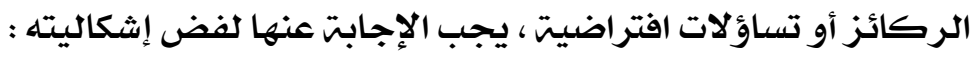

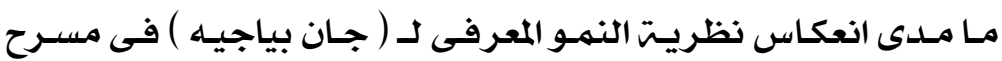

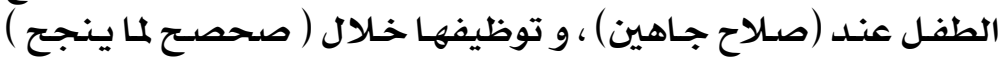

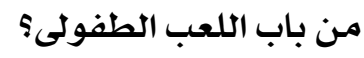

ما هى صور التشابك بين استلهام المؤلف المسرحى للطفل لعناصـر مـن التراث بصورة حدوراثيت ؟

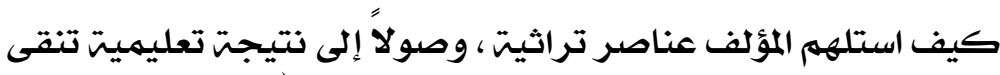

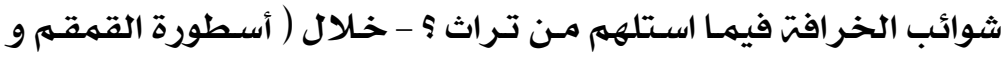

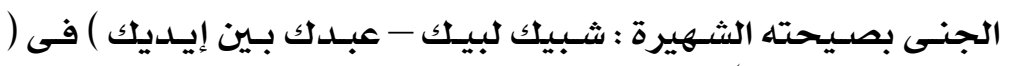

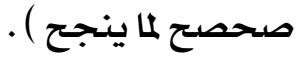

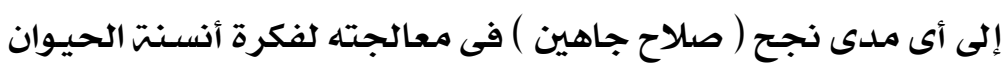

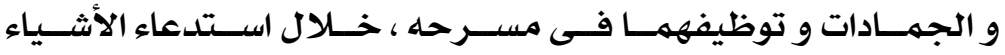




\section{منهج البحث}

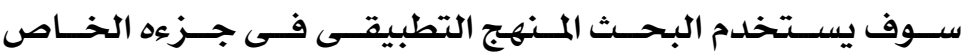

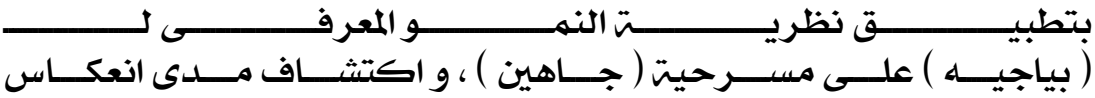

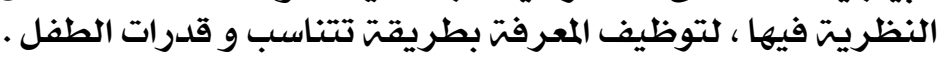

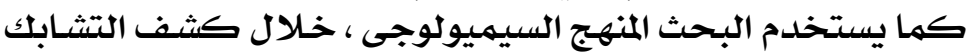

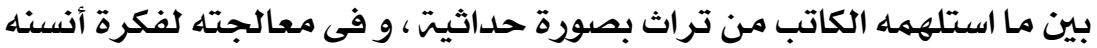
الحيوان و الجماد و دلالات توظيفها.

\section{المبحث الأول}

نظريت (بياجيه) فى ( النهو المعرفى ) و قراءات الباحثين حولها

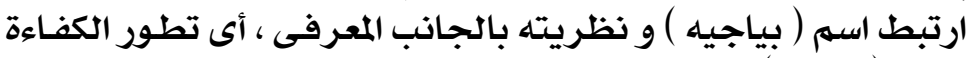

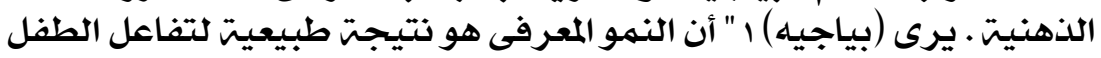

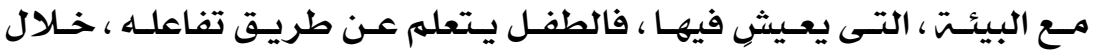

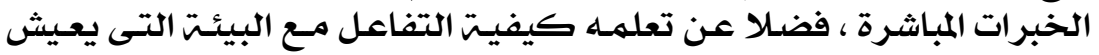

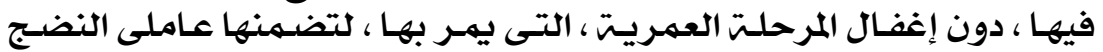

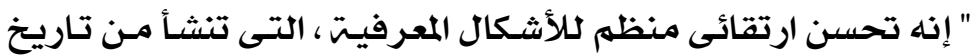

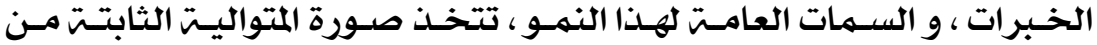

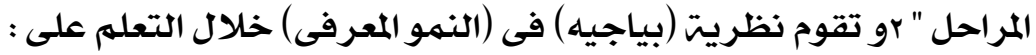

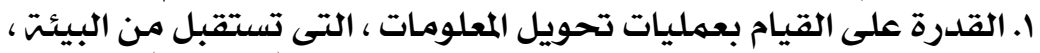

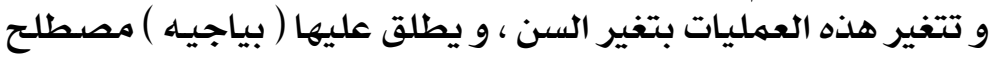

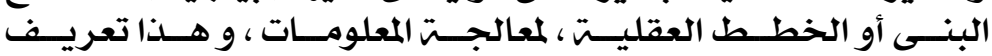

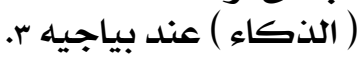

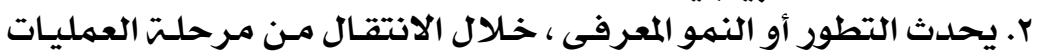

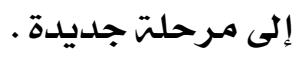

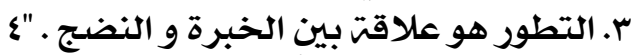

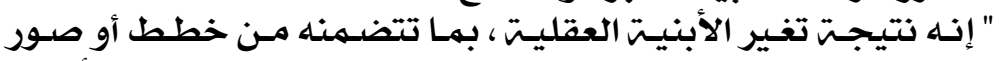

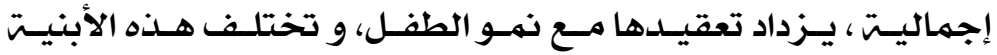

'ا انظر فى : جان بياجيه " سيكولوجيت الذكاء " ت : سيد محمد غنيم ( القاهرة - دار

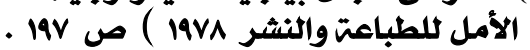

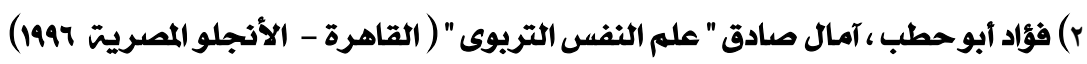
ص 197 فو أوحط.

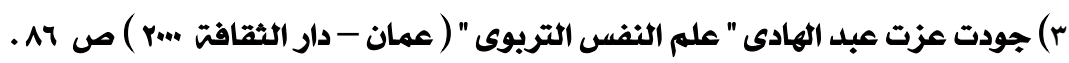

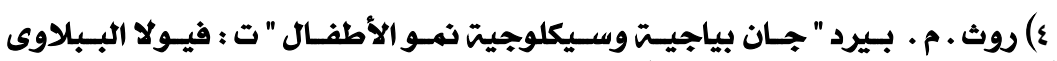

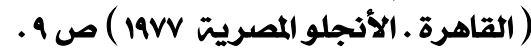


العقليت اختلافاً كيفياً من مرحلت لآخرى ، و من هنا يميز ( بياجيه )

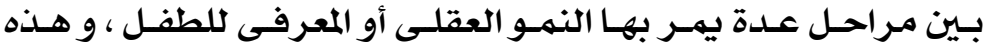

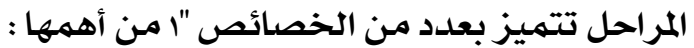

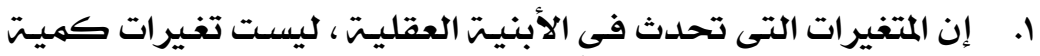

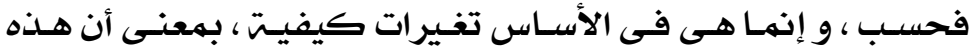
المراحل متداخلت. فوانها

r. هذذه المراحل ثابتت فى نظام تتابع المراحل لدى كل طفل فى كل

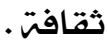

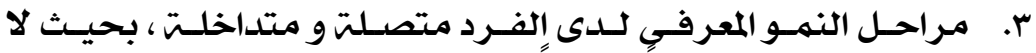

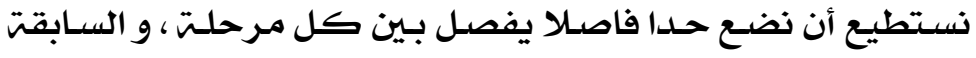

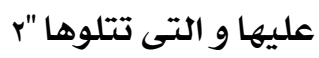

و قــد ميـز (بياجيـهـ) بــين أربـع مـراحـل للنهــو المعرفـى ، تتعلـق بالمفـاهيهم

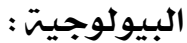

" ( المرحلت الحس حركيت - مرحلت ما قبل العمليات - مـرحلت العمليات

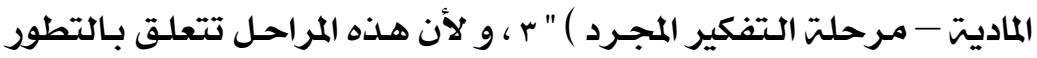

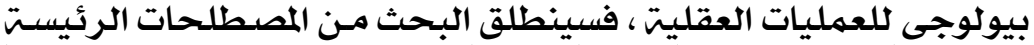

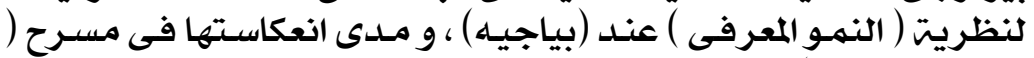

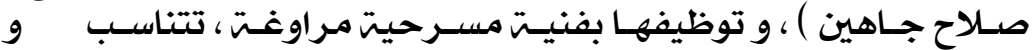

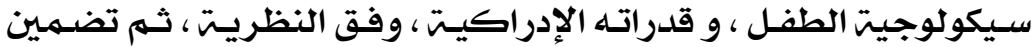

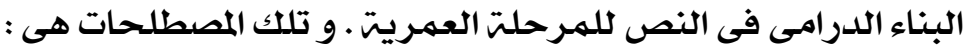

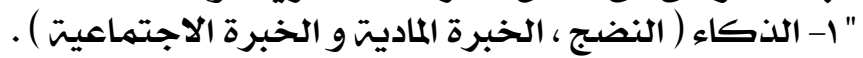

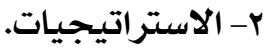

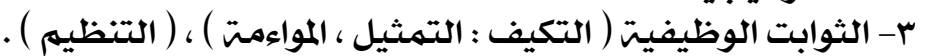

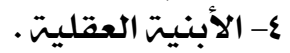

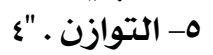

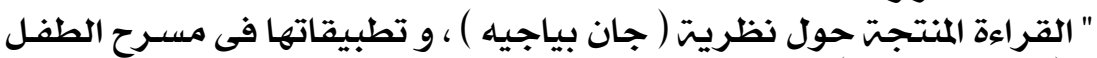

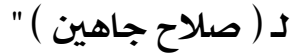

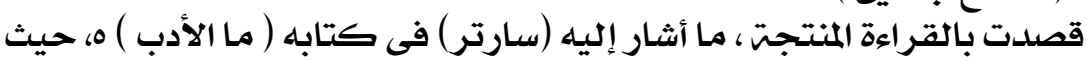

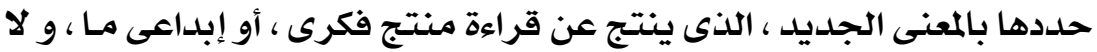

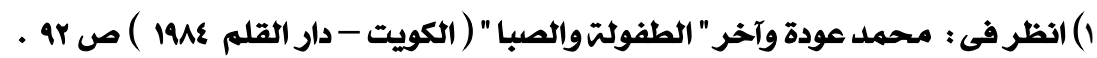

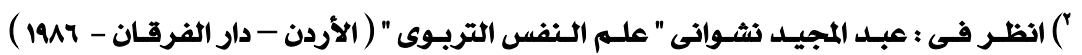

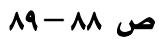
") انظر فى : فاضل محسن الإزير جـاوى " أسس على النفس التربوى " ( الموصل - دار الكتب

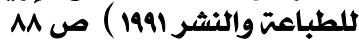
") انظر فى : جان بياجيه" علم نفس الولد " : ت : خليل البحر ( بيرت - المنشورات العربيت IIVr )

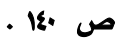
ج) جان بول سارتر " ما الأدب \&" ت : محمد غنيمى هلال (د) ( القاهرة - دار نهضت مصر د / ت ) 


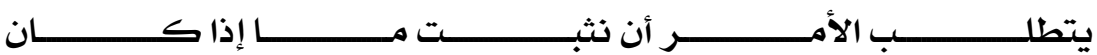

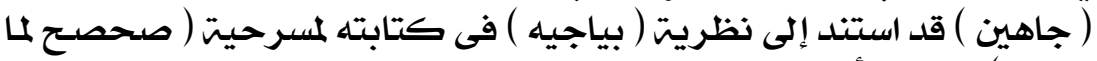

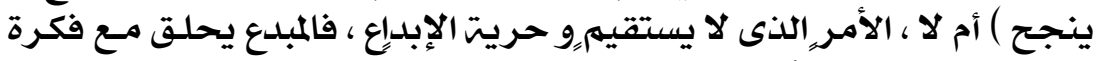

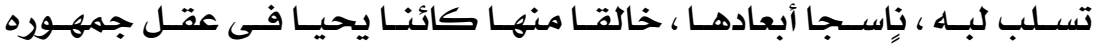

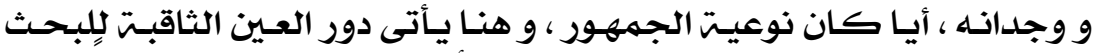

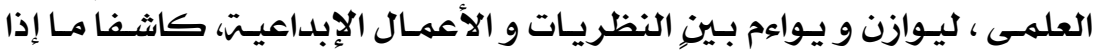

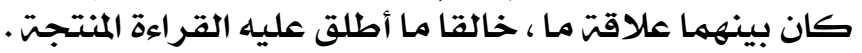

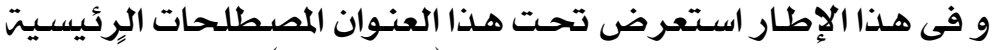

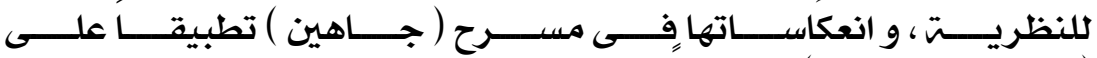

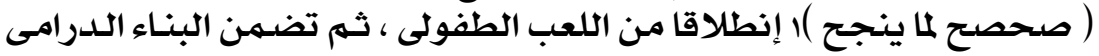

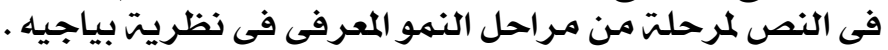

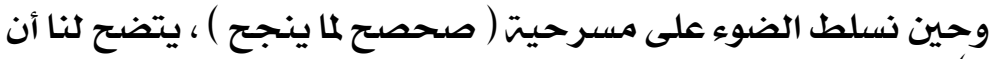

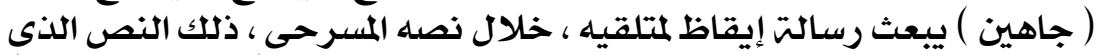

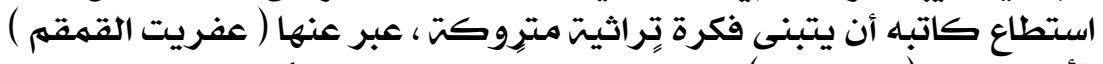

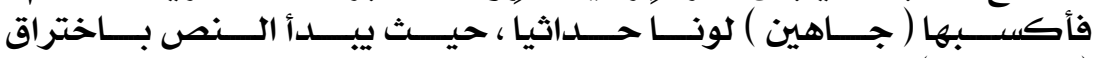

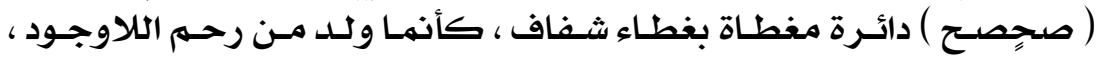

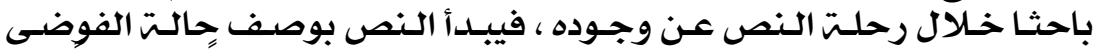

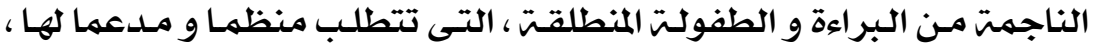

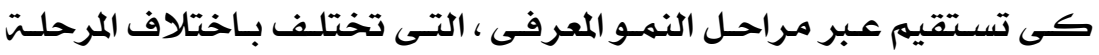

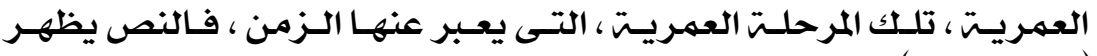

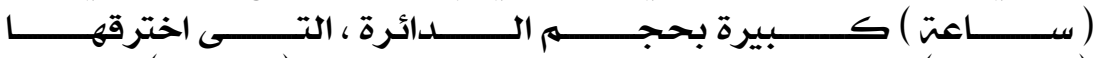

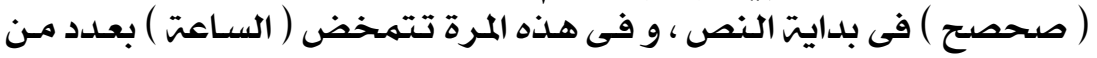

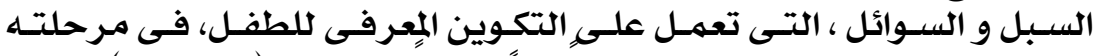

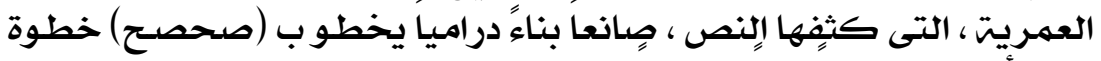

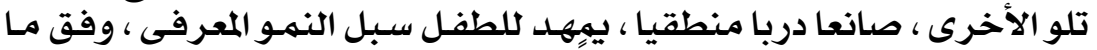

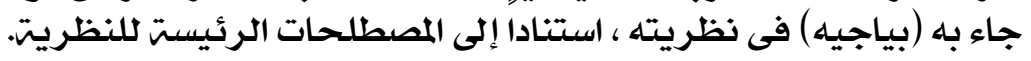

\section{أولاً: الندكاء}

و يشهل ( النضبج ، الخبرة الماديت و الاجتماعيت )

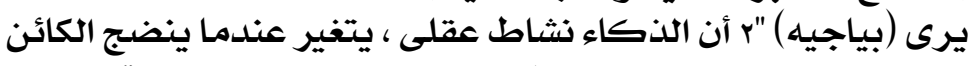

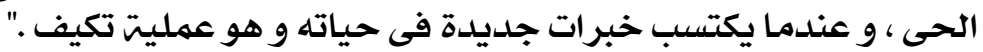

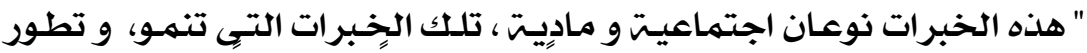

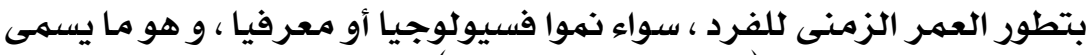

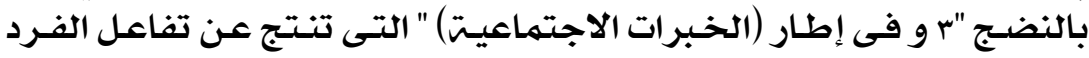

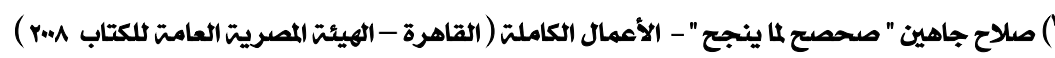

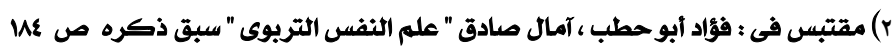

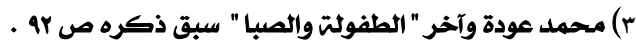




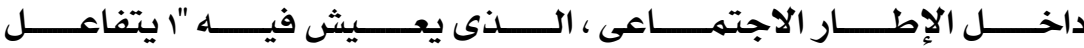

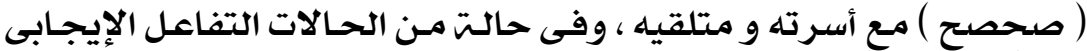

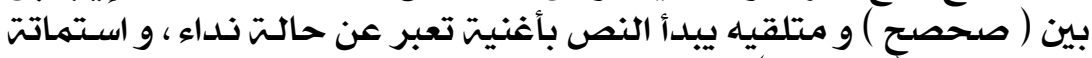
من المتلقى دل (صحصدح).

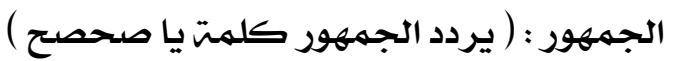

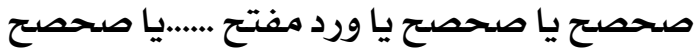

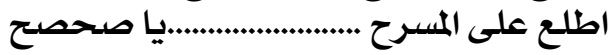

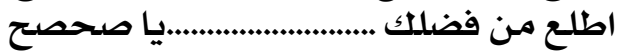

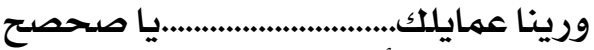

r. خلى الأطفال كلها تفرح

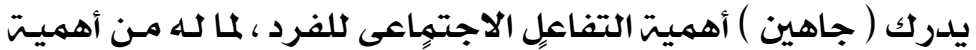

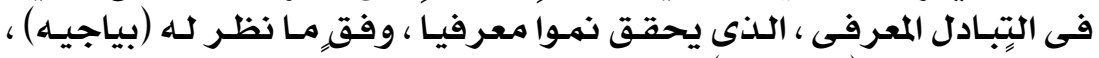

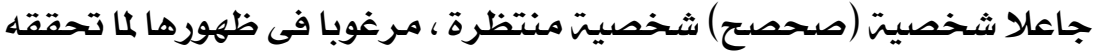

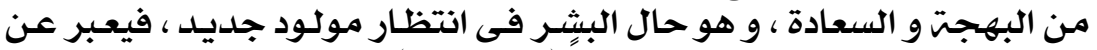

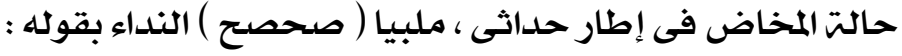

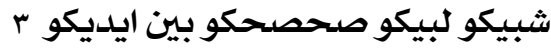

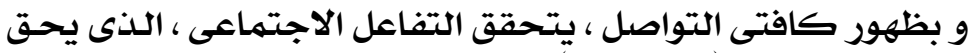

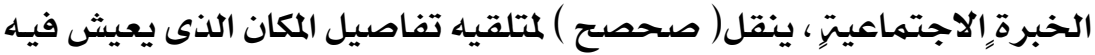

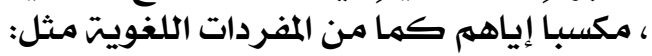

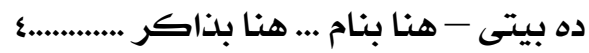

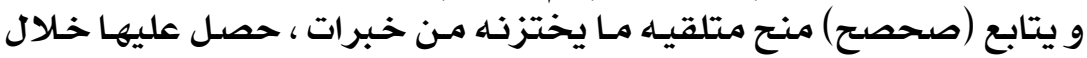

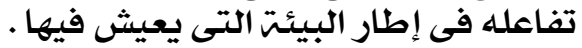

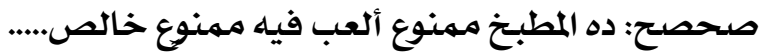

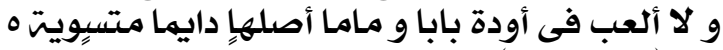

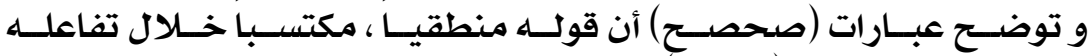

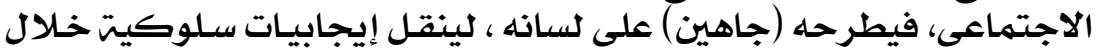
هذا التفاعل .

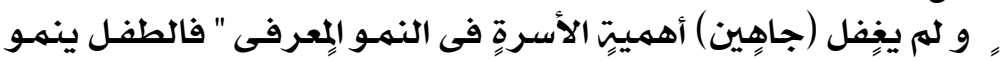

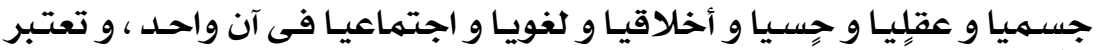

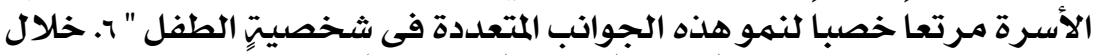

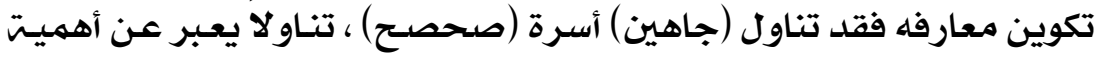

(1) نفسـه (1)

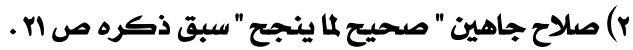

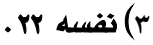

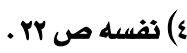

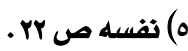

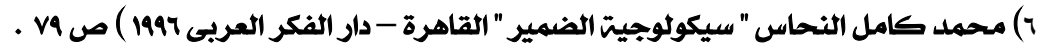




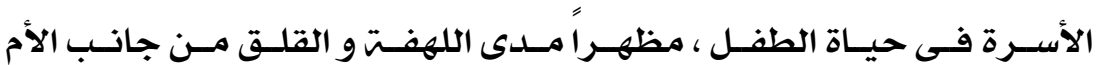

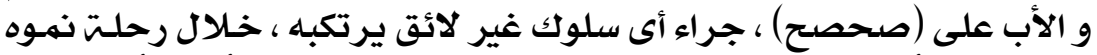

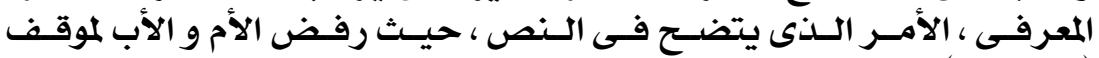

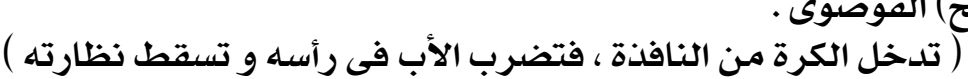

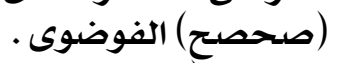

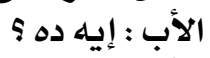

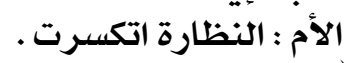

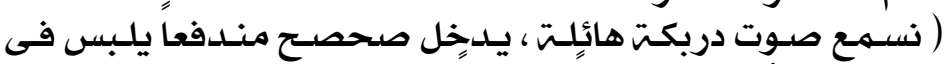

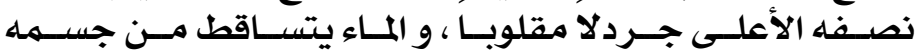

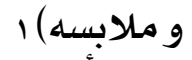

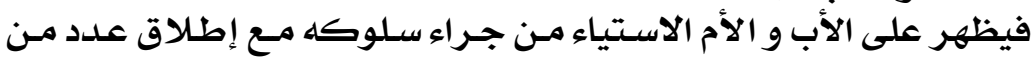

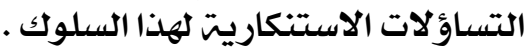

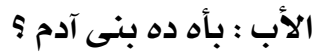

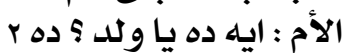

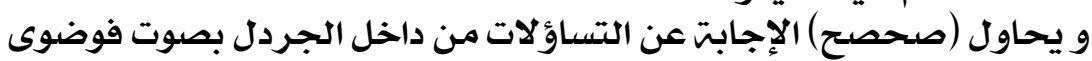

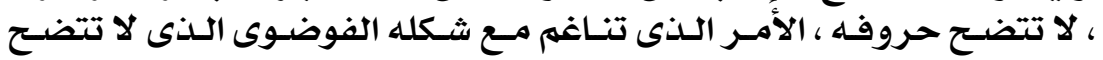

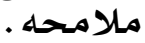

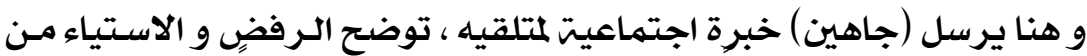

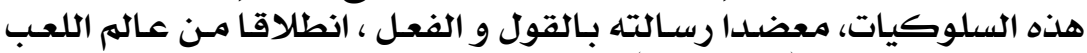

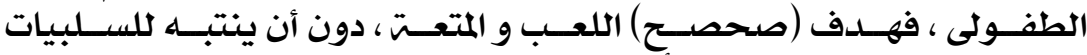

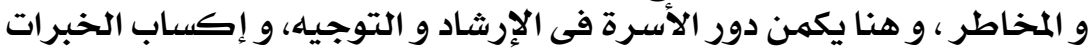

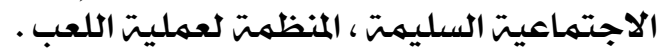

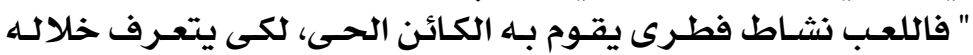

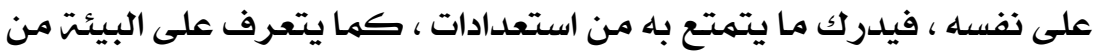

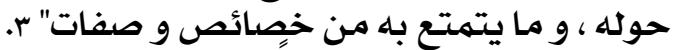

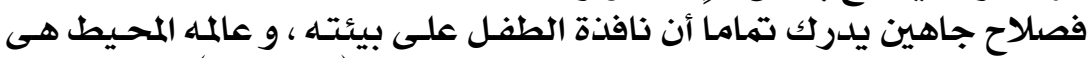

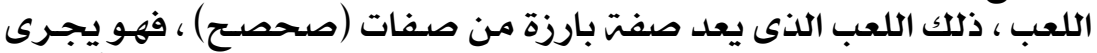

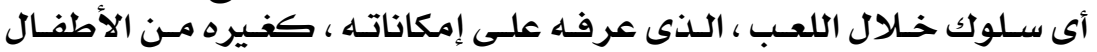
يجرى و يقفز و يغنى و يقلد

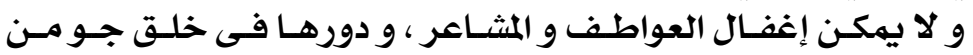

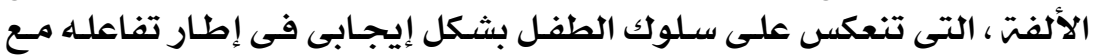

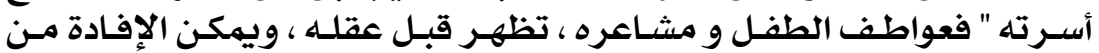

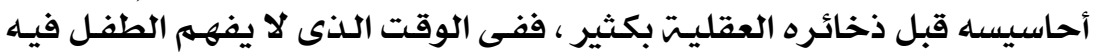

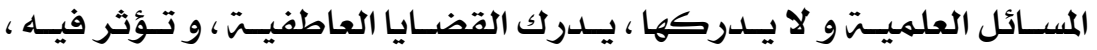

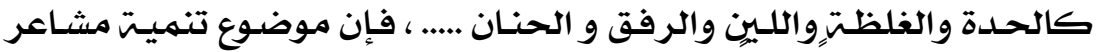

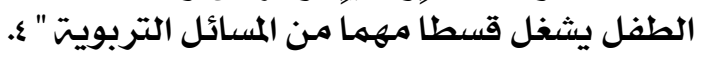

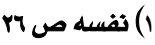

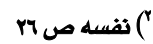

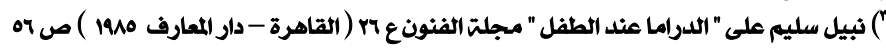

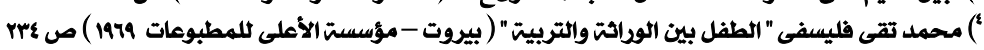




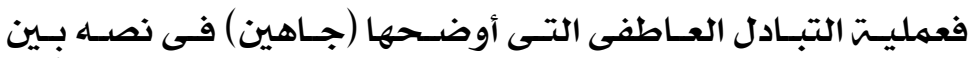

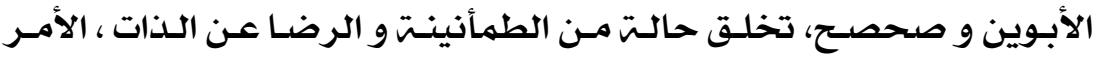

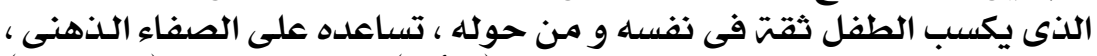

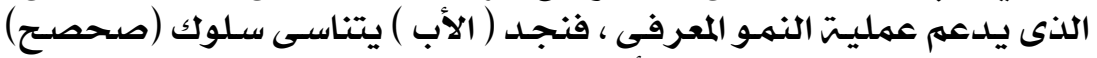
السئ ، و تسيطر عليه عاطفئ الأبن الأبوة.

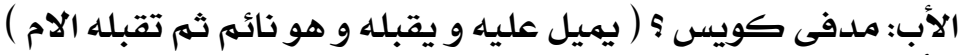

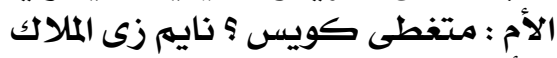

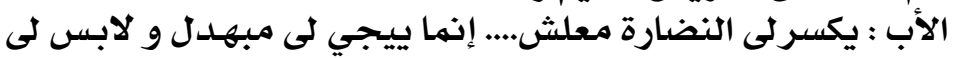

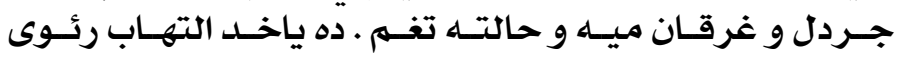
بالشكل ده

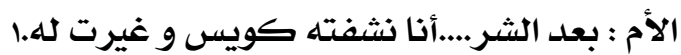

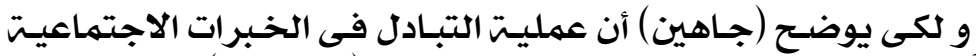

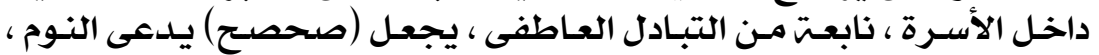

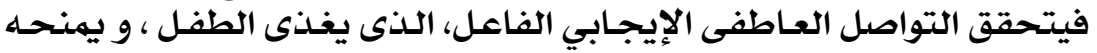

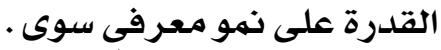

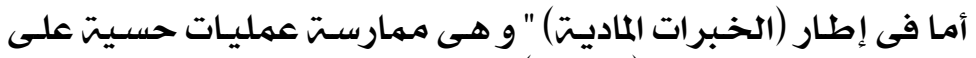

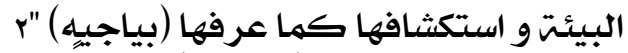

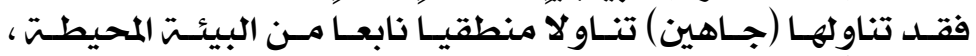

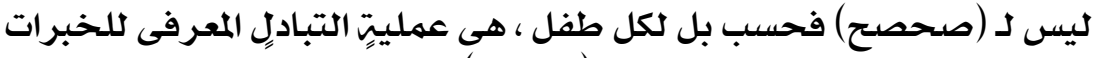

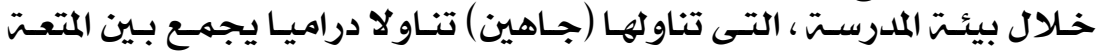

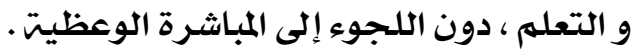

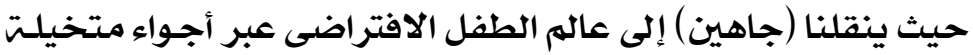

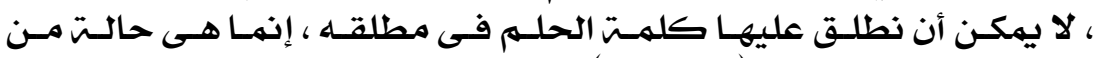

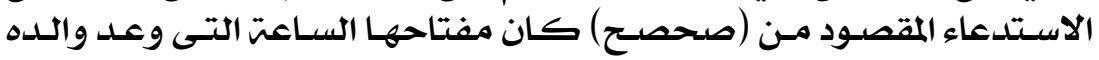

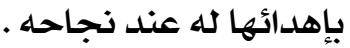

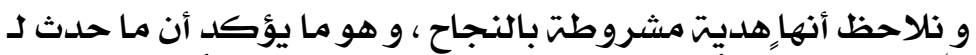

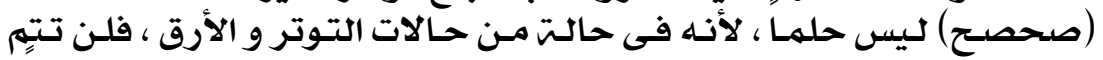

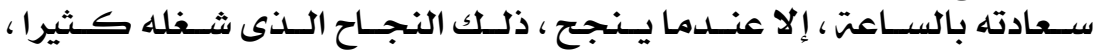

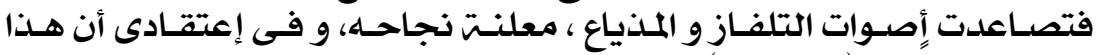

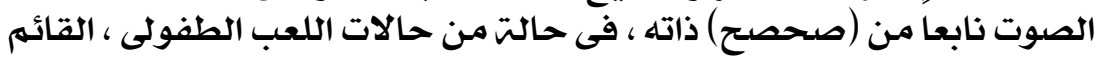

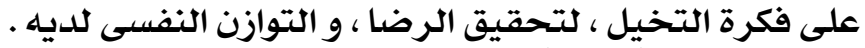

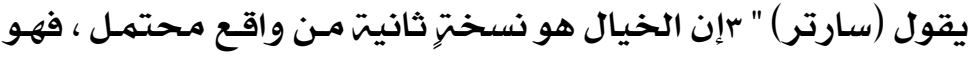

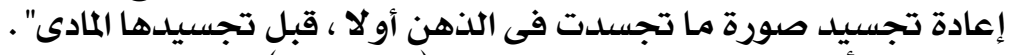

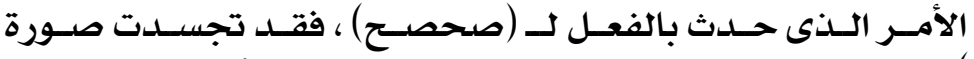

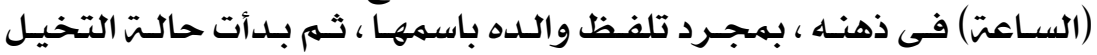
الإبداعى ، محولت الواقع المحتمل فئه إلى واقع فعلى فلى عن طريق الخيال.

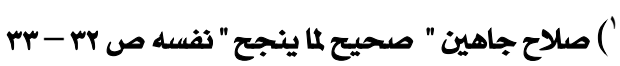

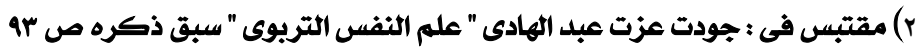

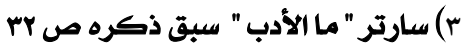




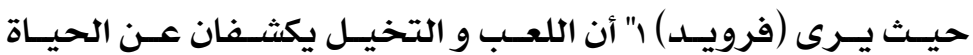

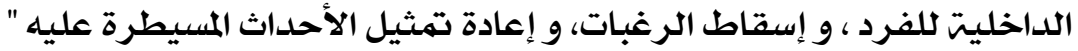

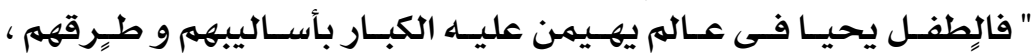

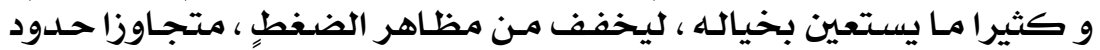

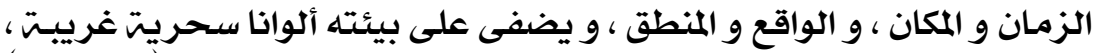

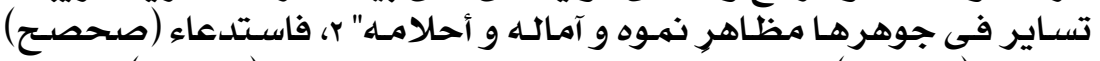

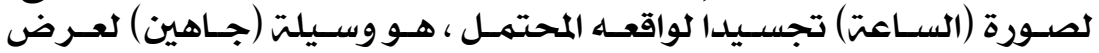

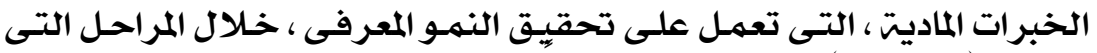

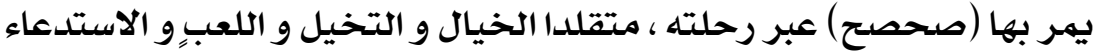

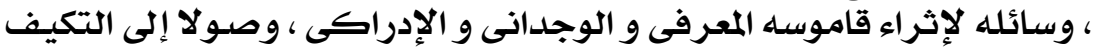

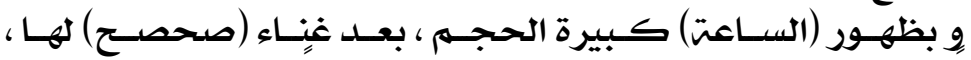

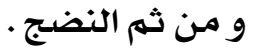

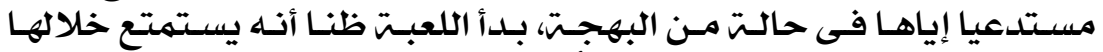

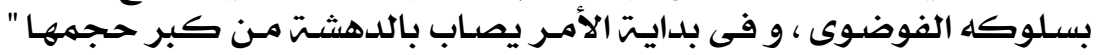

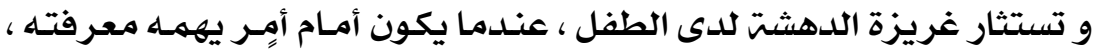

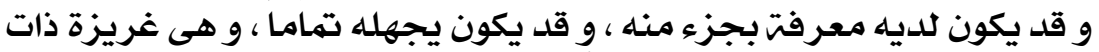

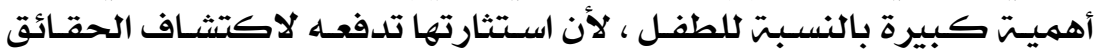

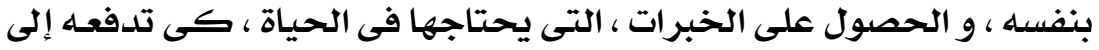

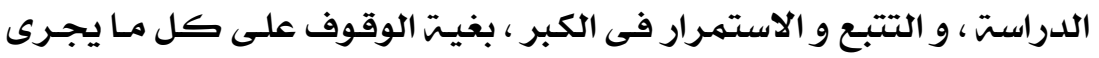

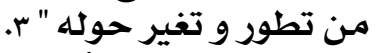

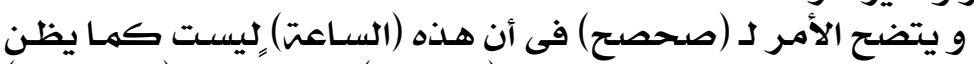

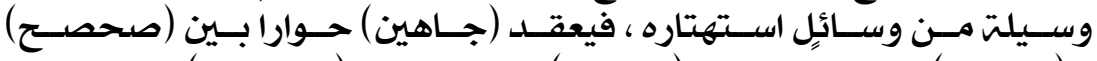

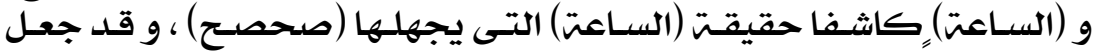

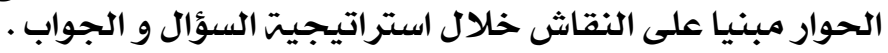

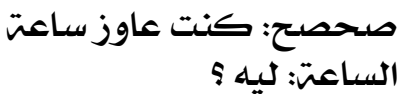

صحصت: عشان نجـان

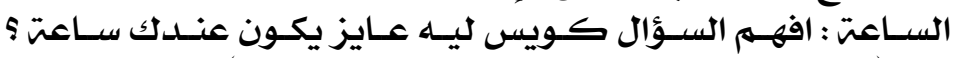

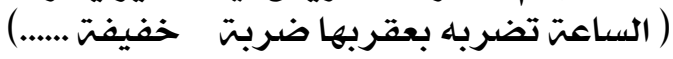

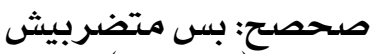

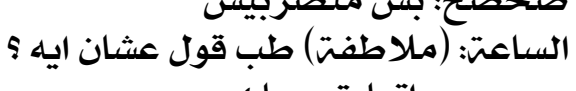

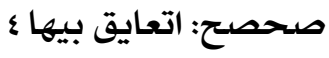

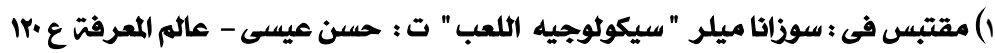

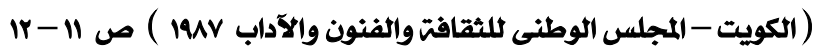

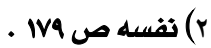
r) أبو الحسن سلام (د) " مسرح الطفل " ( الإسكندريت - دار الوفاء لدنيا الطباعت والنشر ع..r )، ع) صلاح جاهين " صحيح ملا ينجح" سبق ذكره ص اء 


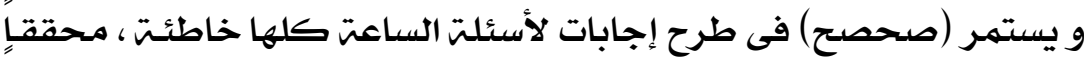

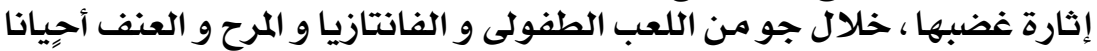

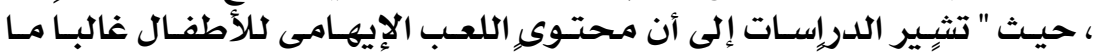

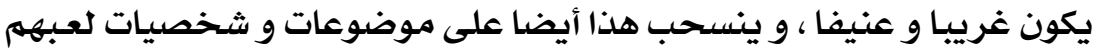

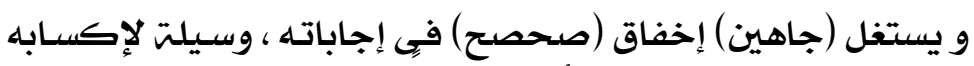

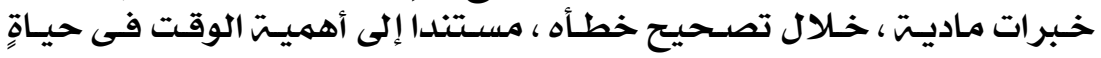

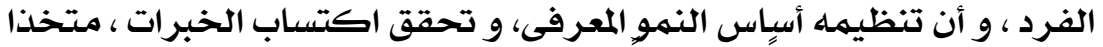

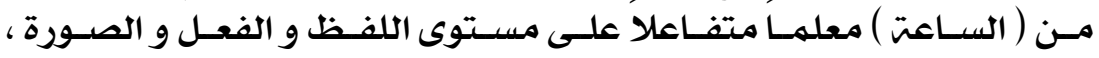

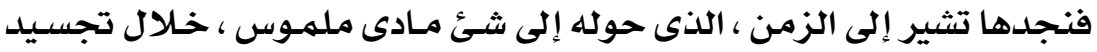

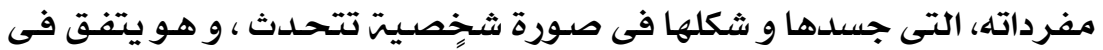

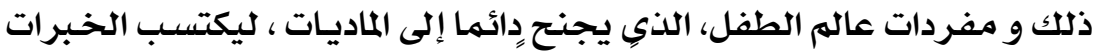

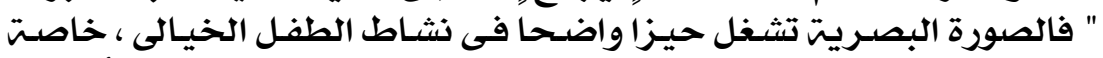

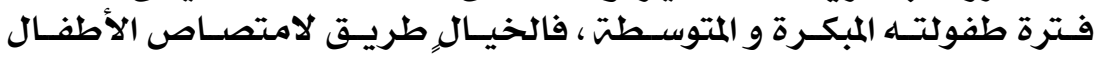

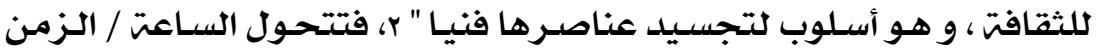

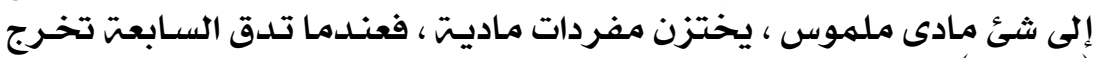

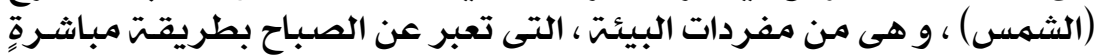

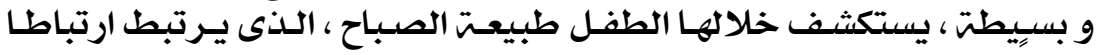
كليا بالشمس ، ونس

$$
\begin{aligned}
& \text { صحصى: ييييه من إلى فتح الثبالك ؟ } \\
& \text { الشمس : أنا ماجيتث من من الشباك إلى فئ الشباك } \\
& \text { أنا جيت من هنا........... }
\end{aligned}
$$

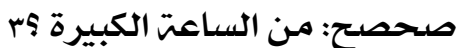

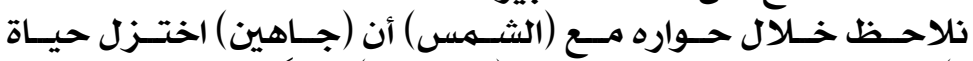

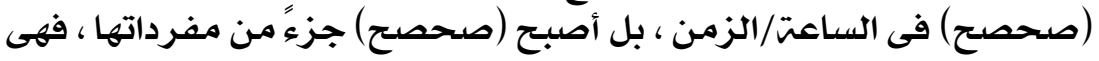

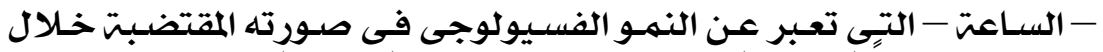

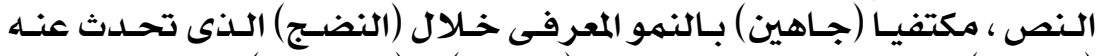

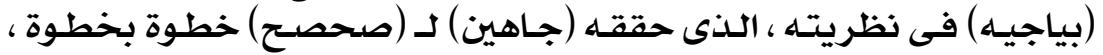

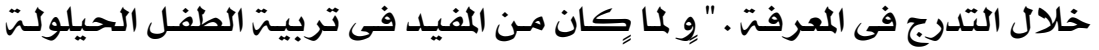

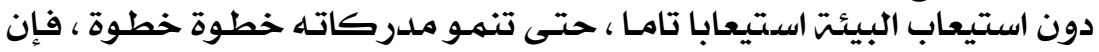

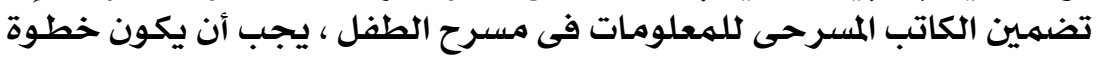

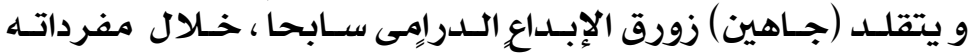

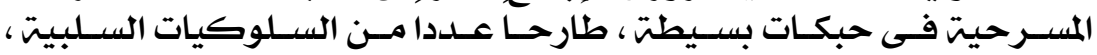

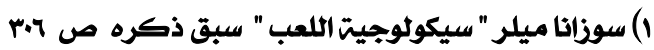

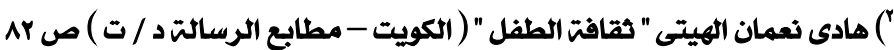

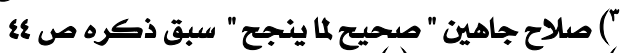

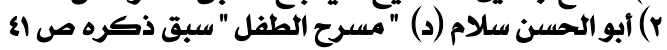


و إحلال قيه إيجابيت ، تسهم فى بناء معرفت الطفل مثل (الإهمال - الكسل -

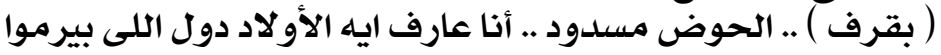

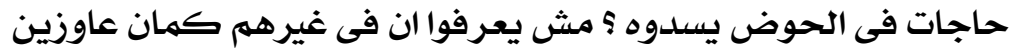

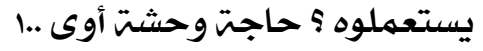

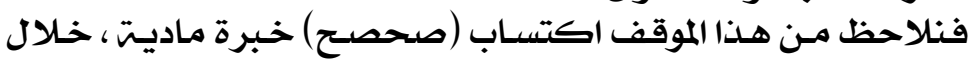

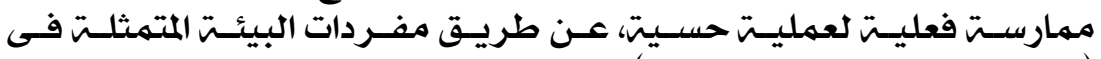

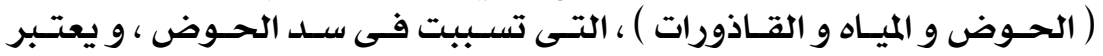

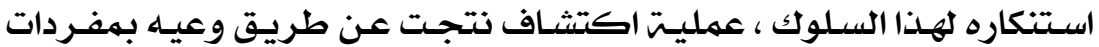

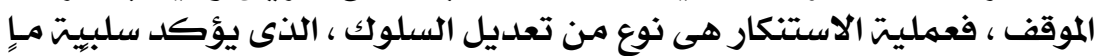

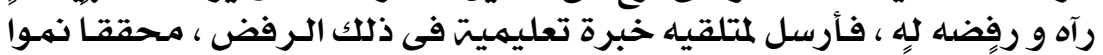

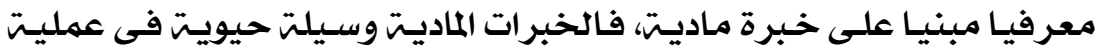

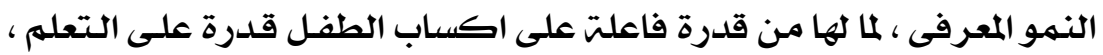

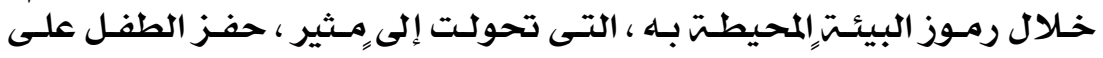

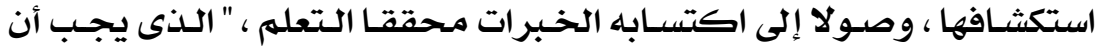

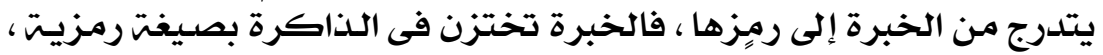

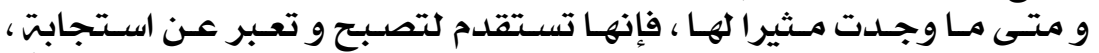

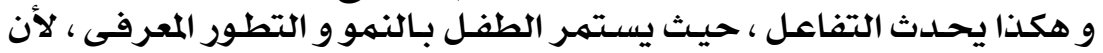

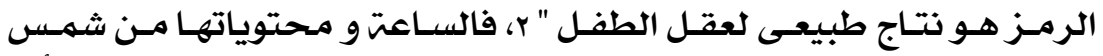

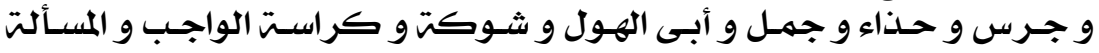

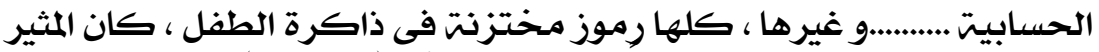

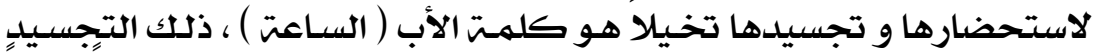

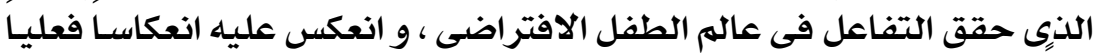

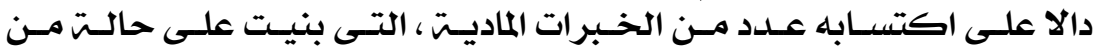

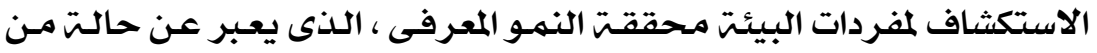

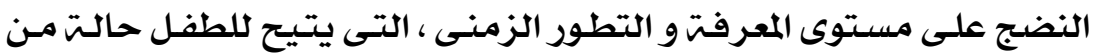
التكيف التى تعبر عن الذئوى المعرفي .

\section{ثانيا : الاستراتيجيات}

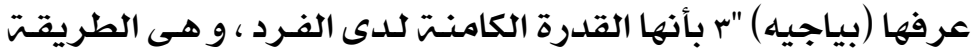

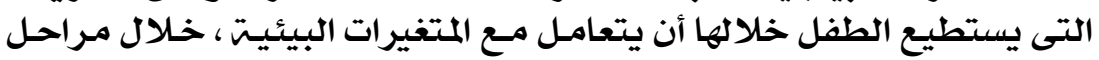

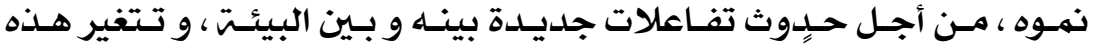

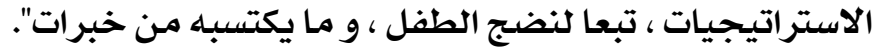
") هربرت ريد " تربيت الذوق الفنى " ت : ميخائيل أسعد ( القاهرة - الأنجلو المصرية - 19v0 ) )

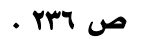
") مقتبس فى : صالح محمد أبوجادو " علم النفس التربوى " ( عمان - دار الميسرة 1991 ) ص 110 


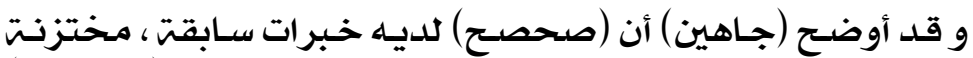

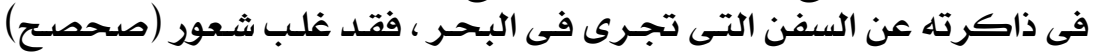

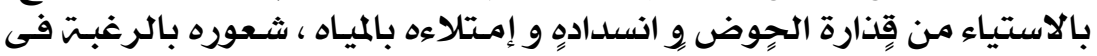

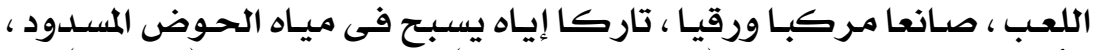

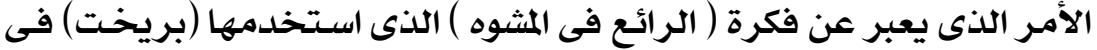

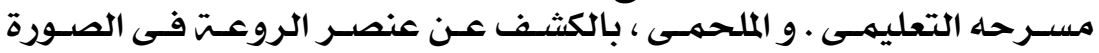

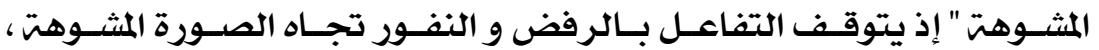

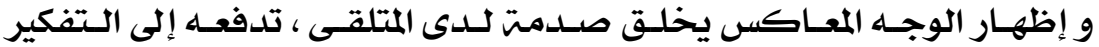

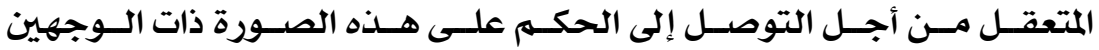

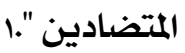

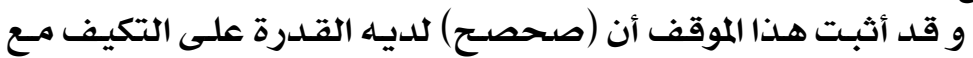

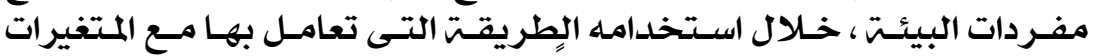

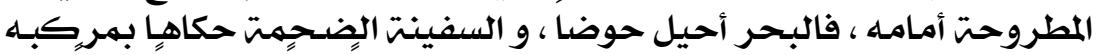

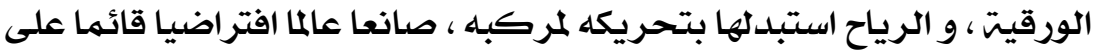

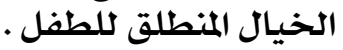

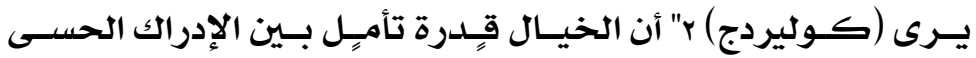

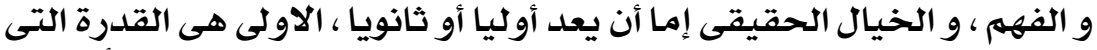

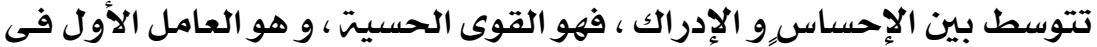

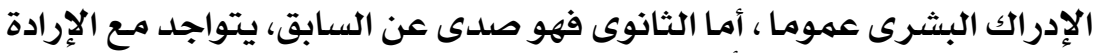

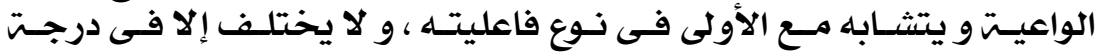

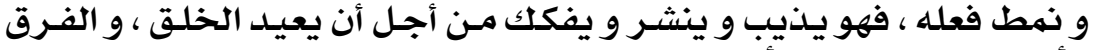

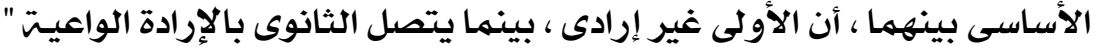

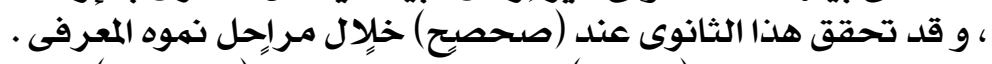

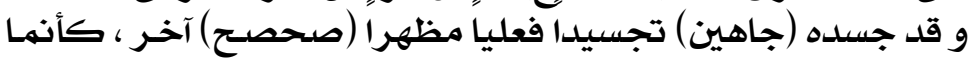

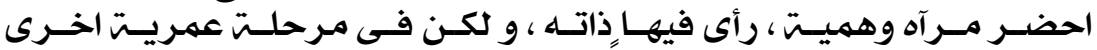

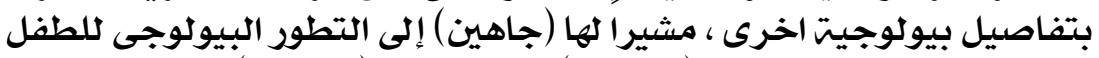

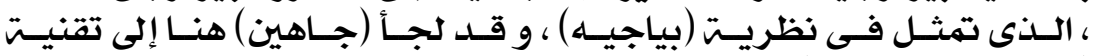

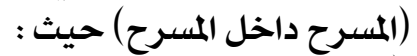

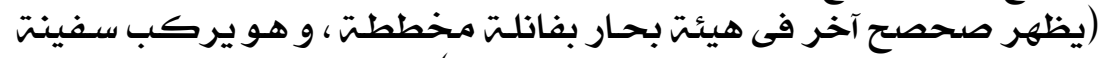

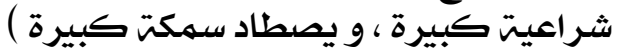

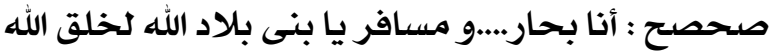

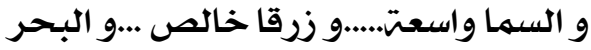

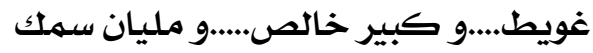
سهك ملون.....أحمر و أخضر الهر و أصفر

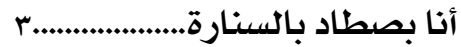

') انظر فى : برتولد بريخت " نظريت المسرح الملحمى " ت : جميل نصيف ( د) ( بيروت - عالم

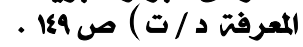

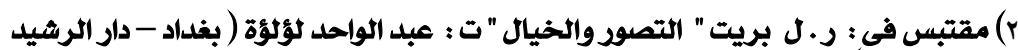

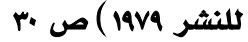

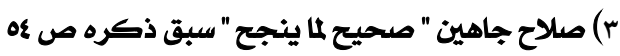
171 


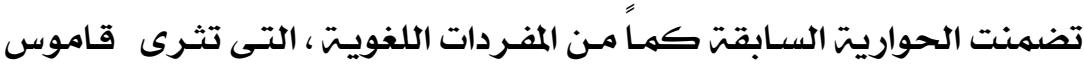

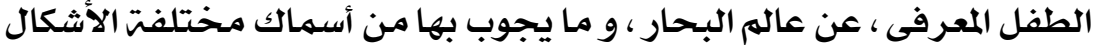

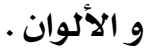

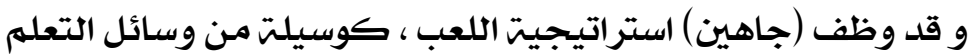

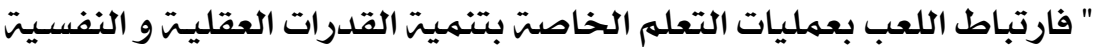

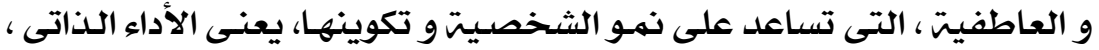

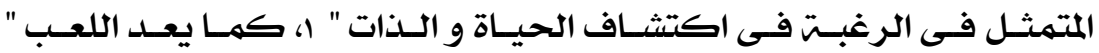

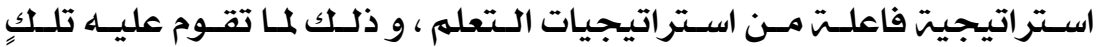

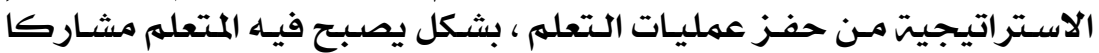

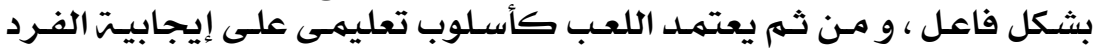

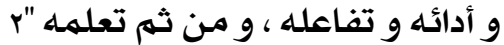

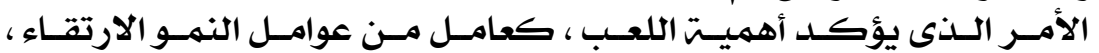

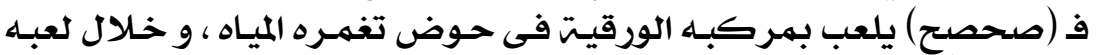

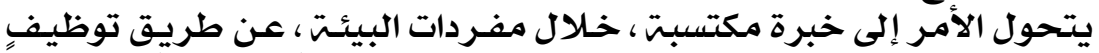

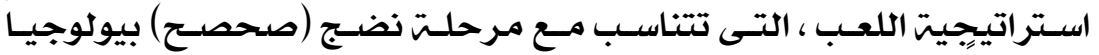

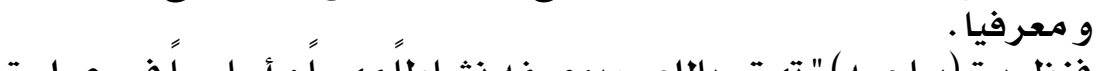

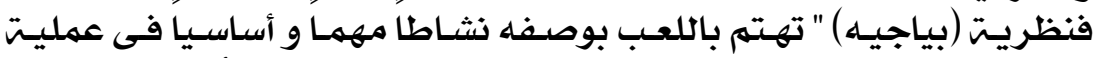

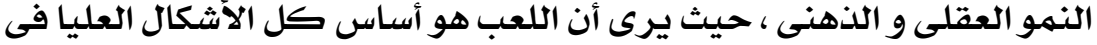

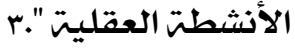

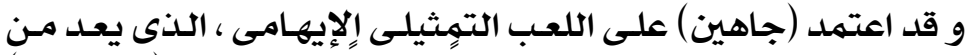

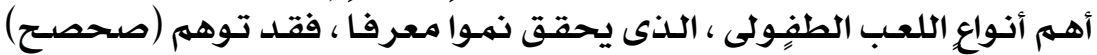

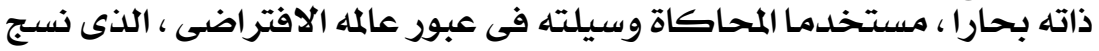

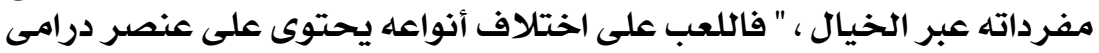

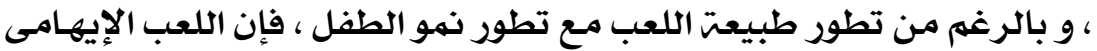

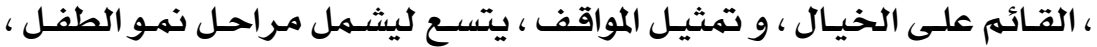

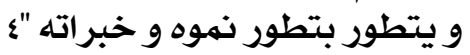

1) فاروق السيد عثمان " سيكولوجيت اللعب والتعليم" ( القاهرة - دار المعارف 1990 ) ص 189 ـ .

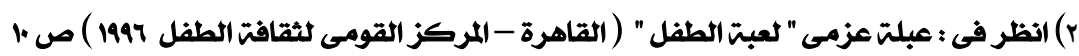

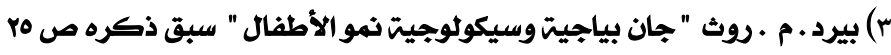
ع) بيتر سليد " دراما الطفل " ت : كمال زاخر لطيف ( الإسكندريت - منشأة المعارف IAVV ) 


\section{ثالثاً الثوابت الوظيفيت}

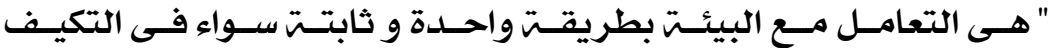

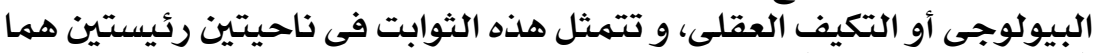

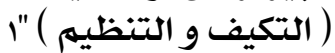

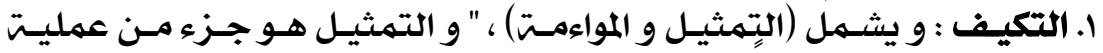

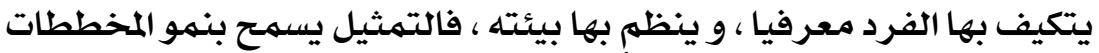

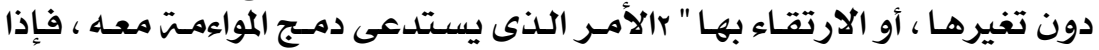

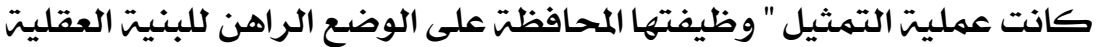

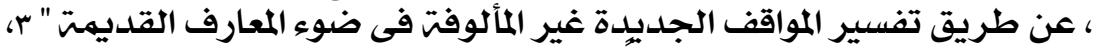

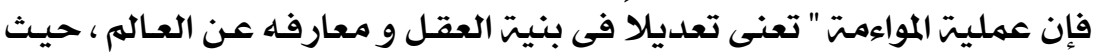

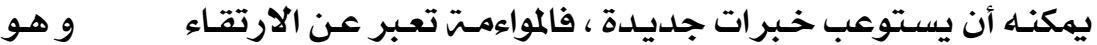
9

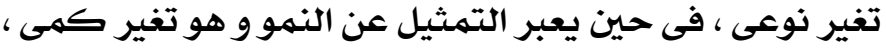

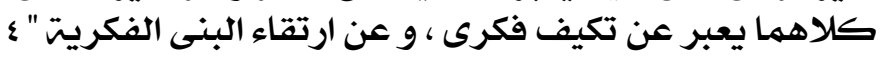

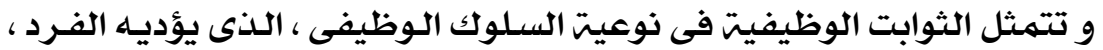

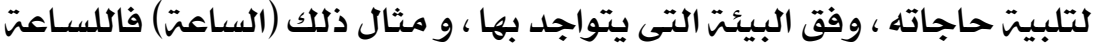

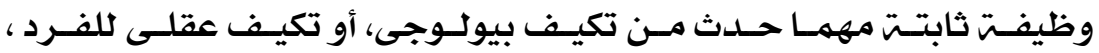

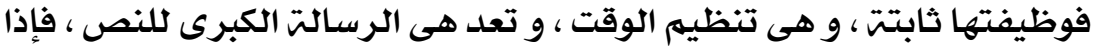

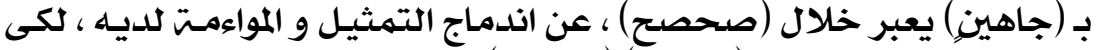

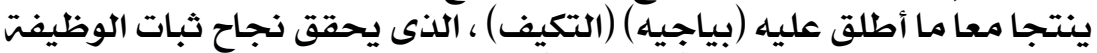

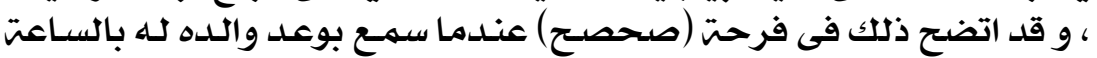

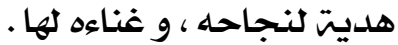

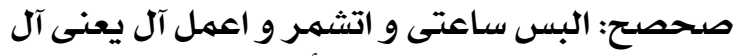

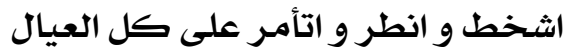

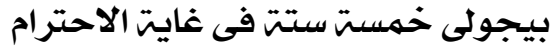

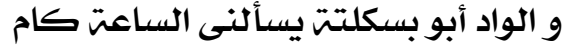

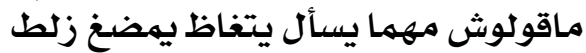

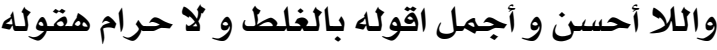

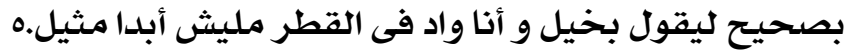

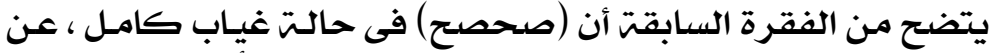

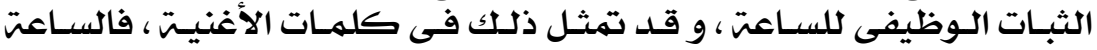

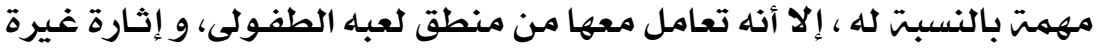

1) سليمان الخضرى الشيخ " الفروق الفرديت فى الذكاء" ( القاهرة - دار الوفاء للطبامت .199) ص T.7r)

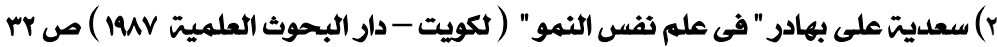

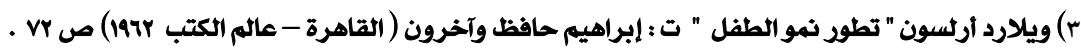
ع) سليمان الخضرى الشيخ " الفروق الفرديت فى الذكاء " ثفسه ص عز 0) صلاح جاهين " صحيح لما ينجح " سبق ذكره ص .ع 


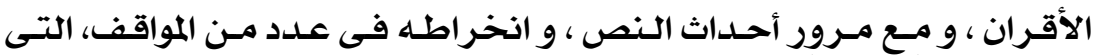

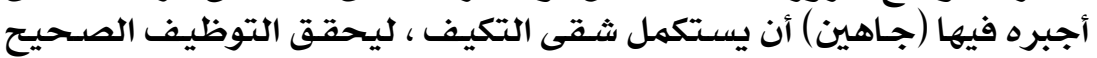

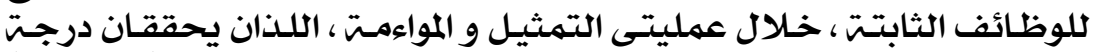

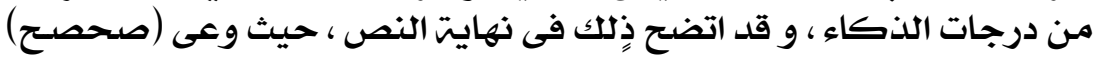

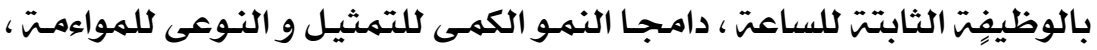

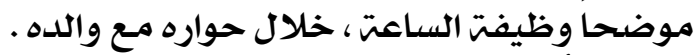

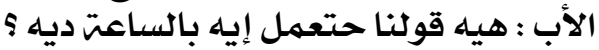

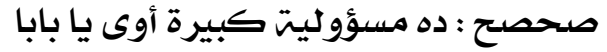
مش عياقت و لا فنطازيت...

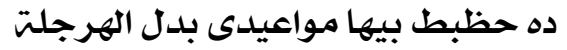

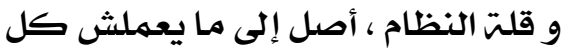

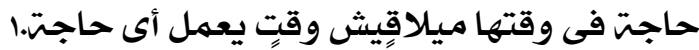

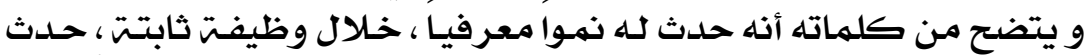

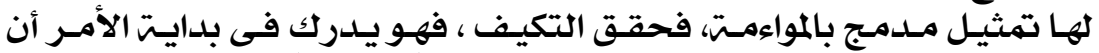

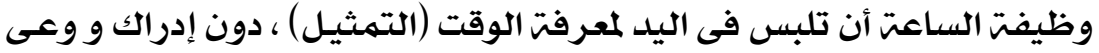

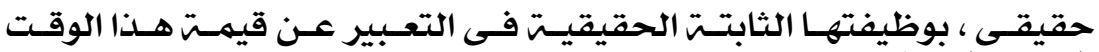

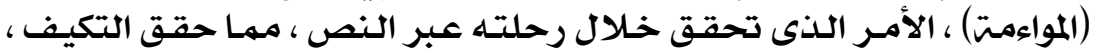

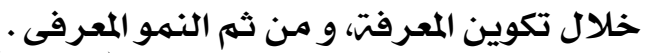

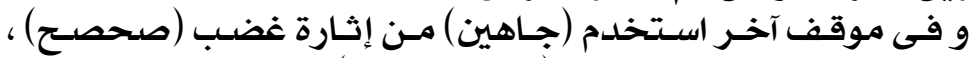

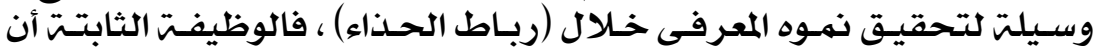

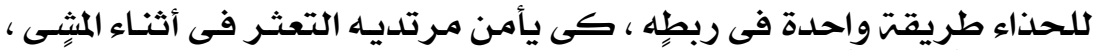

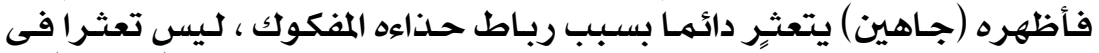

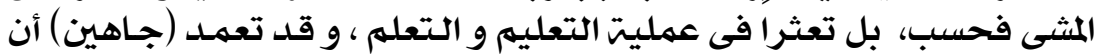

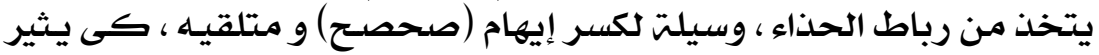

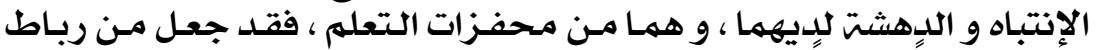

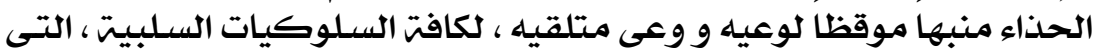

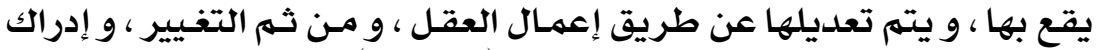

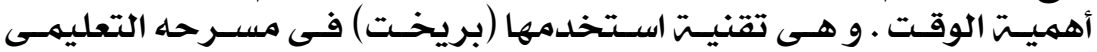

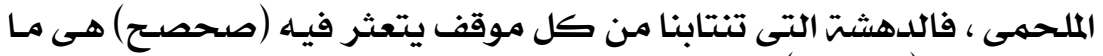

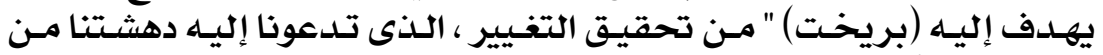

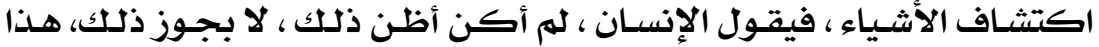

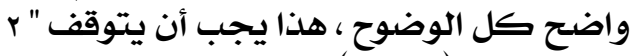
صحصح : (يجرى الوضوح) حاضر

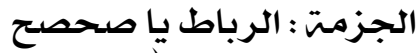

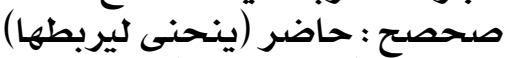
الجرس : (ينقض عليه) تلالهم لهم يلا أوام

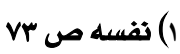

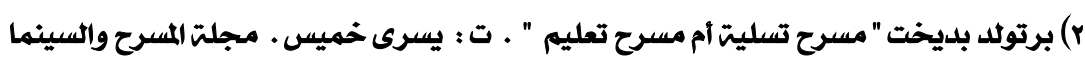

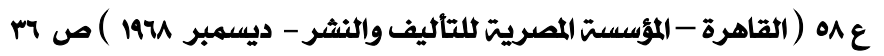


صحصح : يعنى ما أربطث الرباط (يدوس على الرباط و يقع)

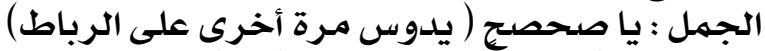

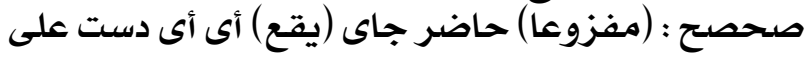
الرباط تانى ............

الشوكت : يا صحصتح : الشرى

صحصس : طب جاي بس بس أربط رباط الجزمته

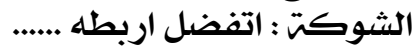

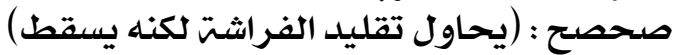

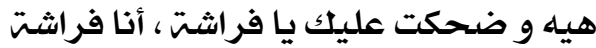

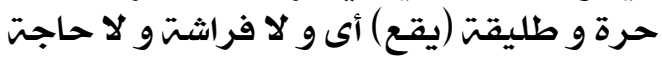

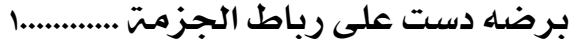

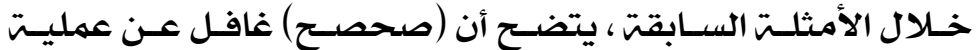

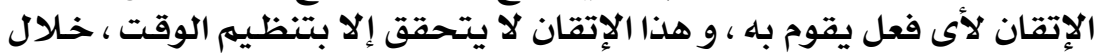

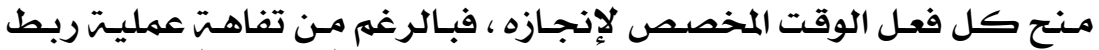

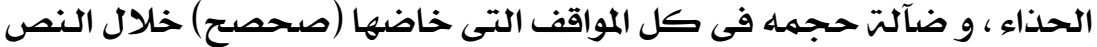

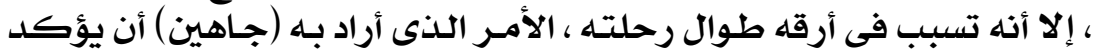

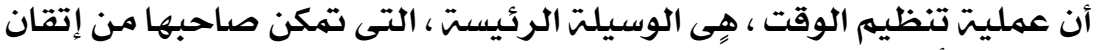

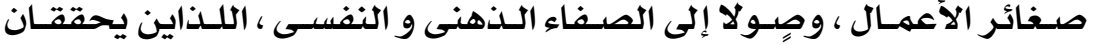

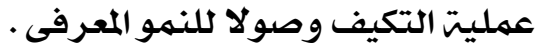

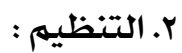

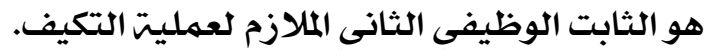

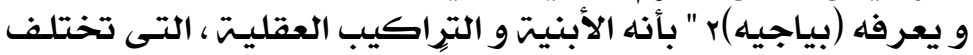

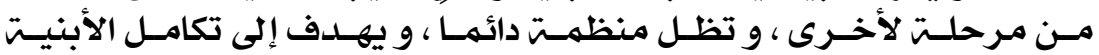

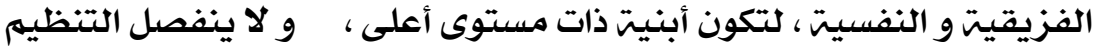

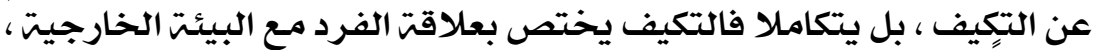

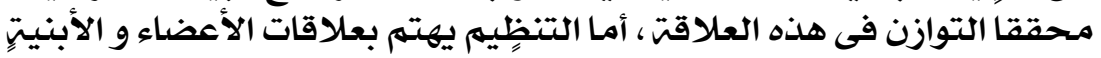

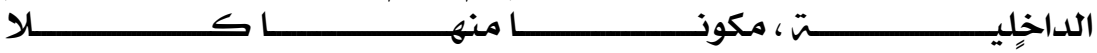

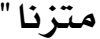

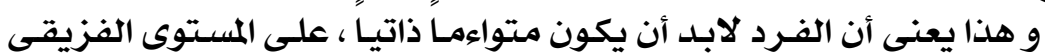

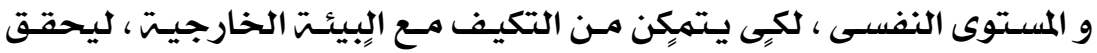

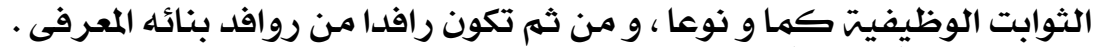

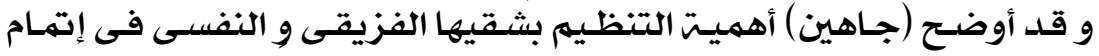

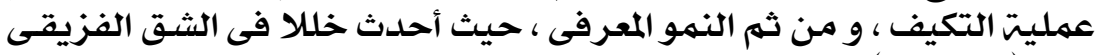

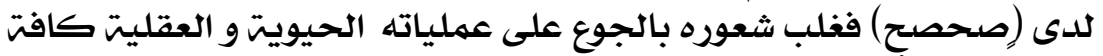

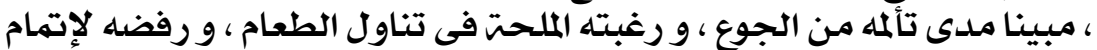

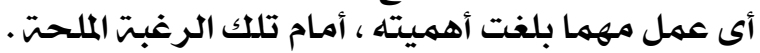

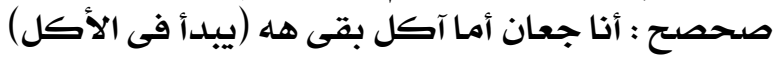

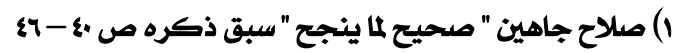

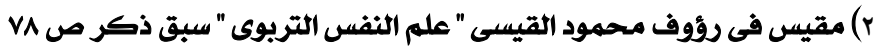


(فجـأة ينفـتح مكــان الســاعت الخامسـت مـن الســاعت و تخــرج

$$
\begin{aligned}
& \text { كراست الواجب) }
\end{aligned}
$$

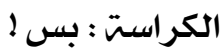

$$
\begin{aligned}
& \text { صحصح : ايله ؟ } \\
& \text { الكراستّ : مش معاده : معاد }
\end{aligned}
$$

صحصح : آمال معاد : معاد ايله ؟

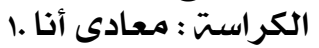

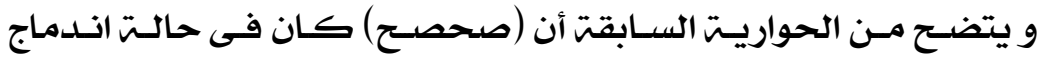

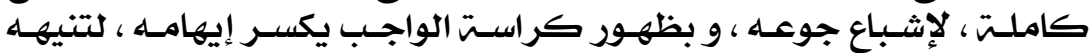

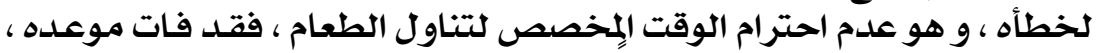

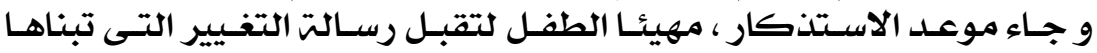

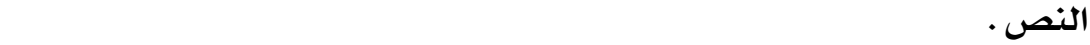

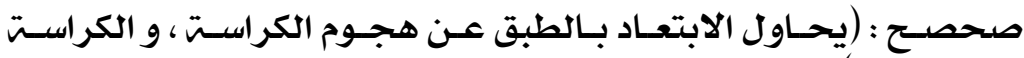

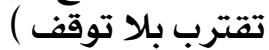

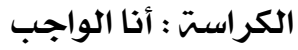

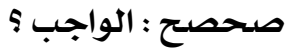

الكراستة : اعملنى : الواجي

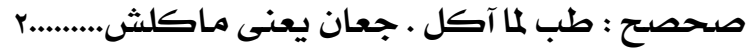

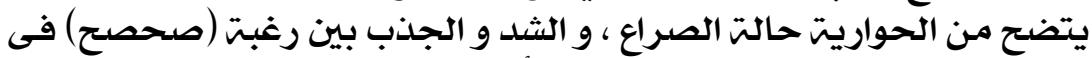

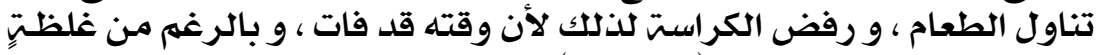

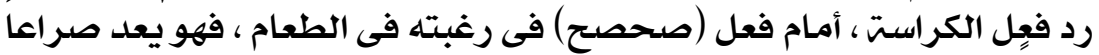

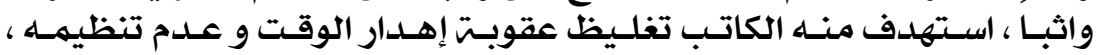

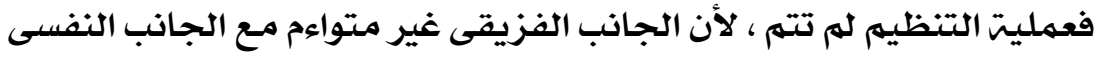

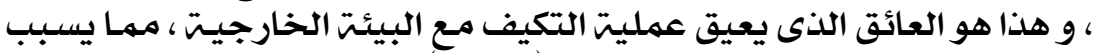

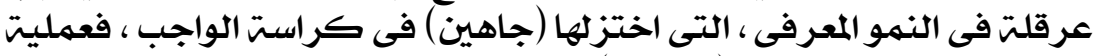

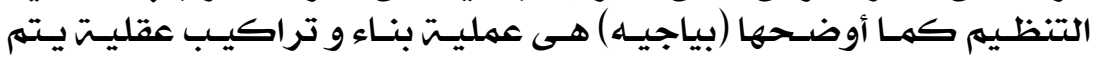

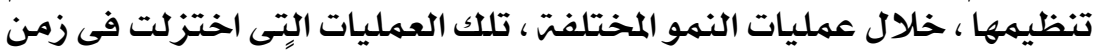

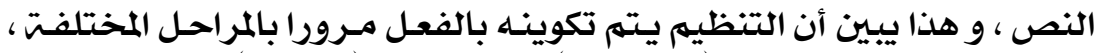

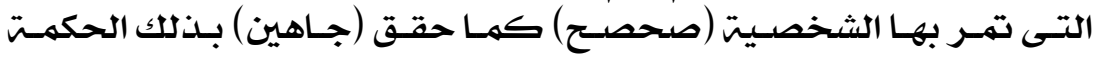

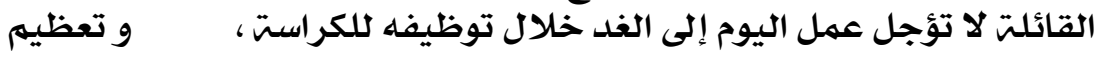

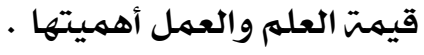

\section{رابعاً : الأبنيت العقليت}

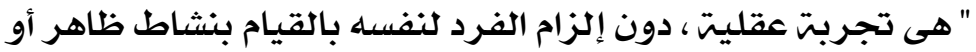

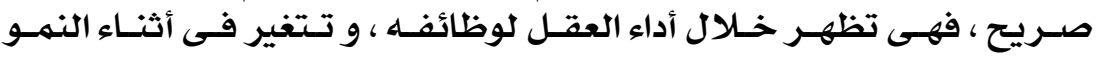

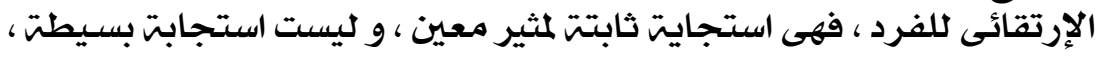

1) صلاح جاهين " صحيح ملا ينجح " سبق ذكره ص rr

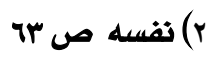


و إنما هى استجابت معقدة ، تتضمن العمليات الحسيت الحركيت و العمليـات

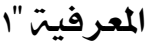

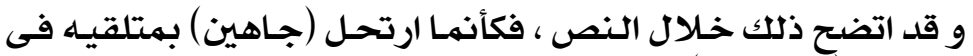

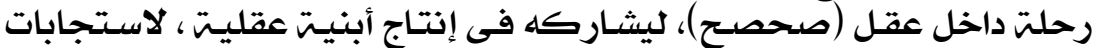

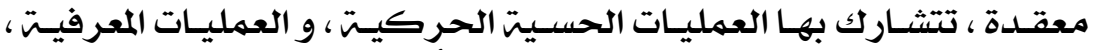

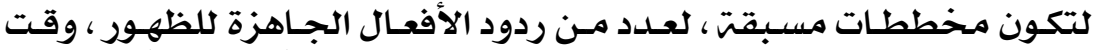

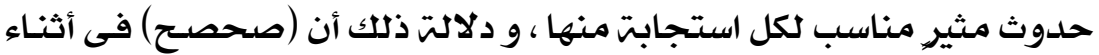

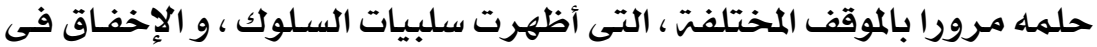

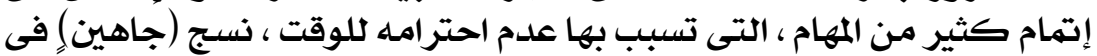

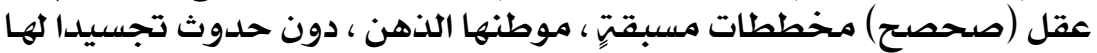

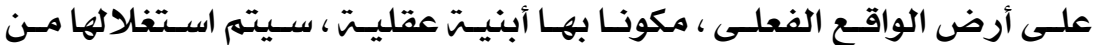

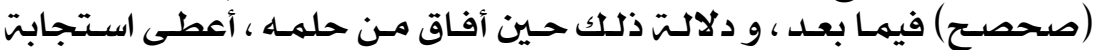

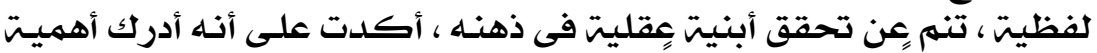

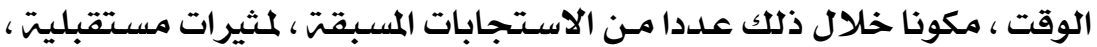

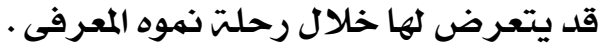

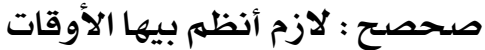

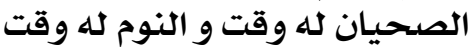

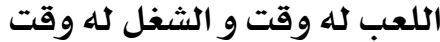

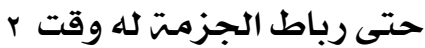

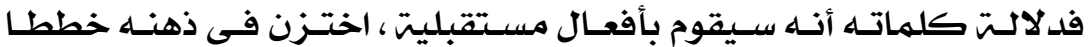

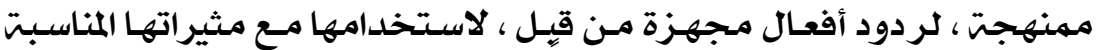

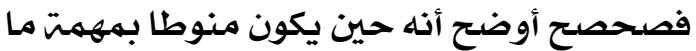

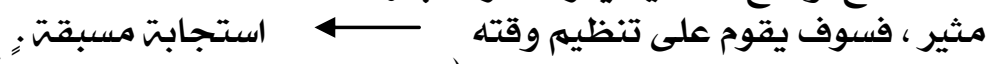

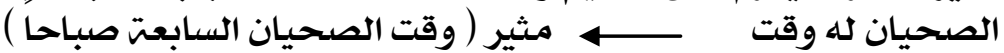

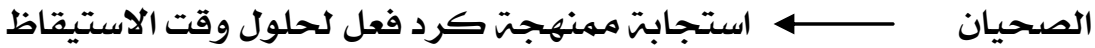

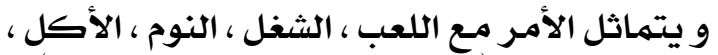

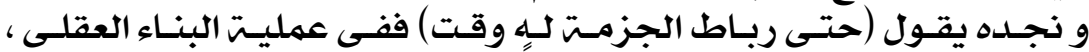

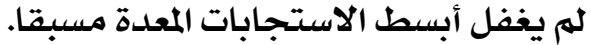

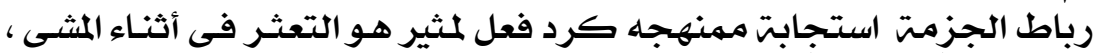

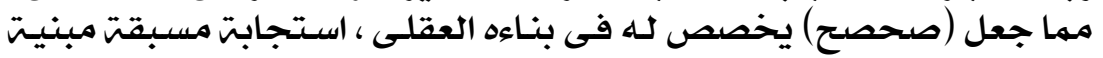

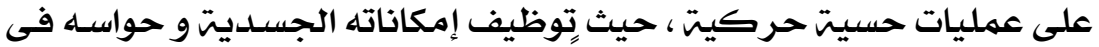

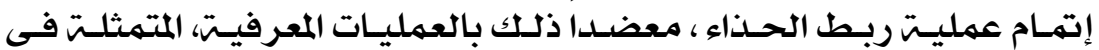

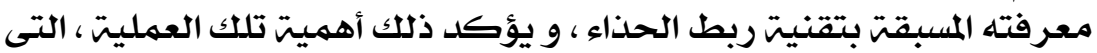

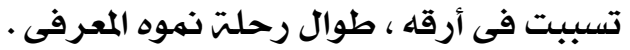

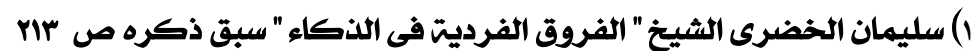

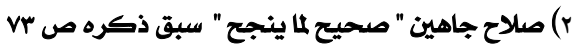




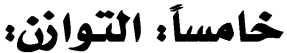

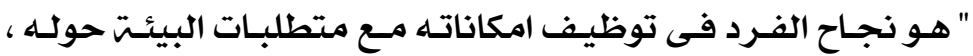

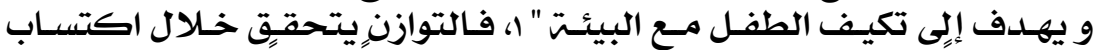

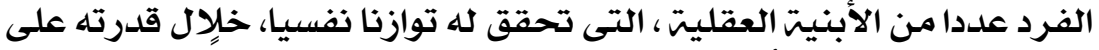

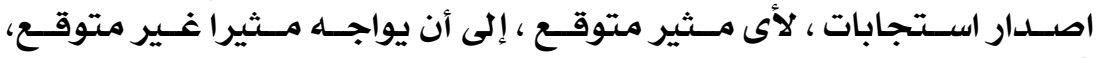

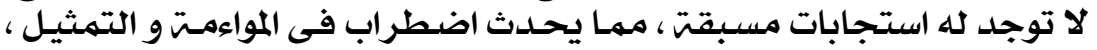

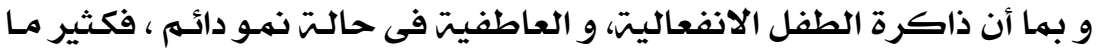

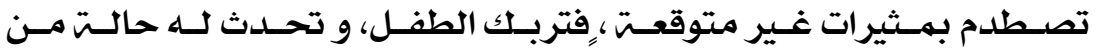

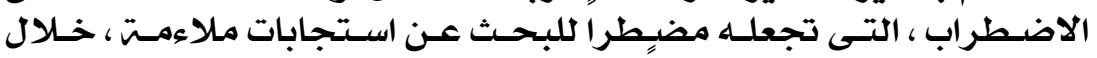

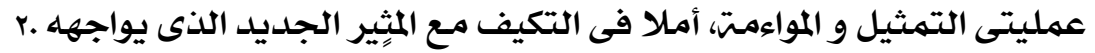

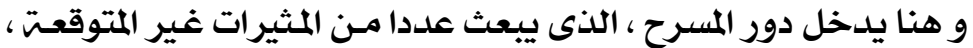

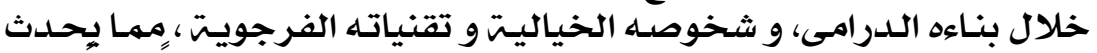

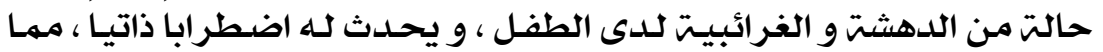

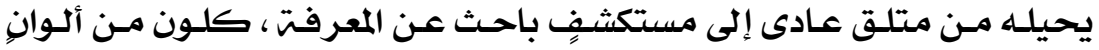

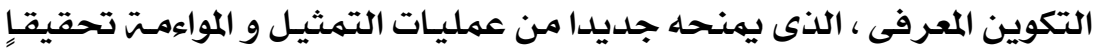

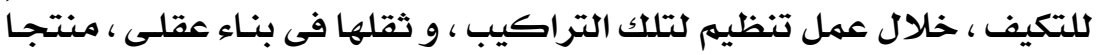

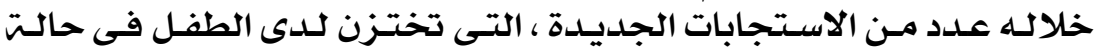

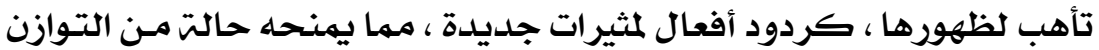

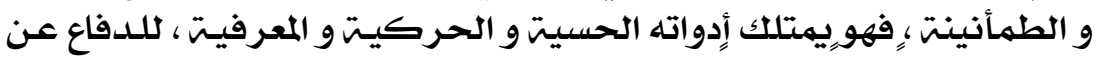

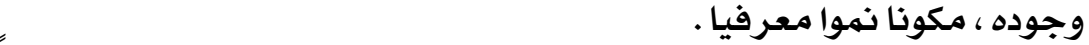

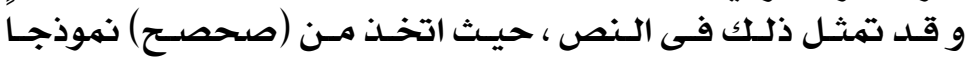

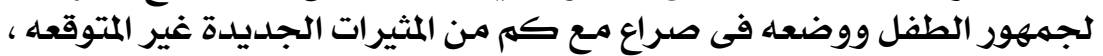

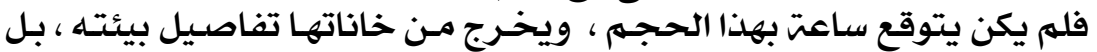

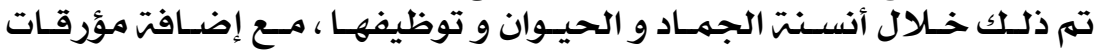

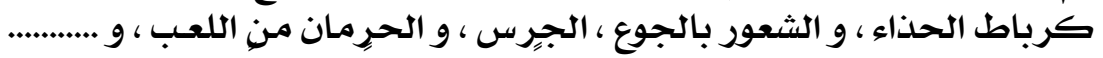

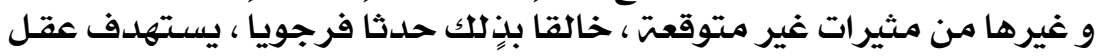

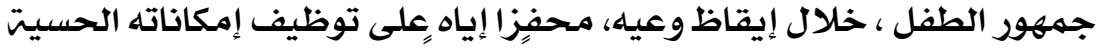

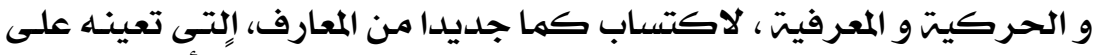

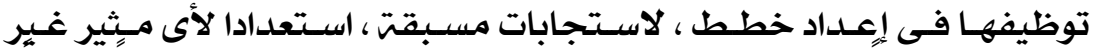

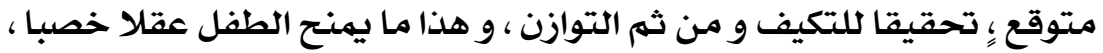

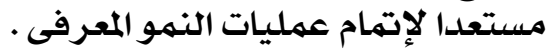

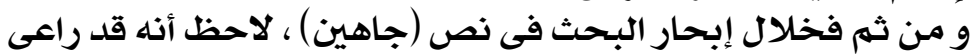

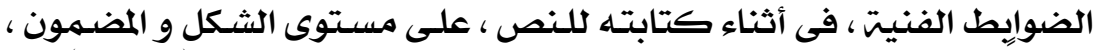

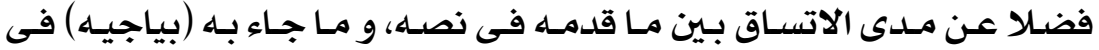

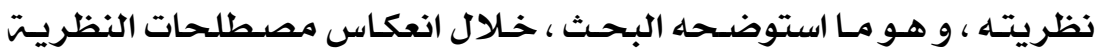

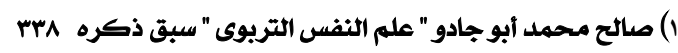

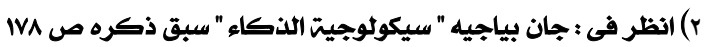




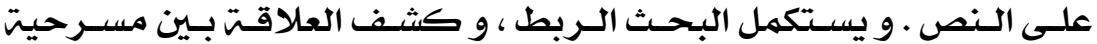

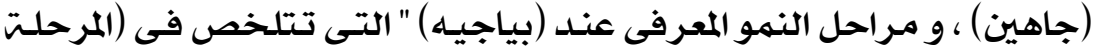

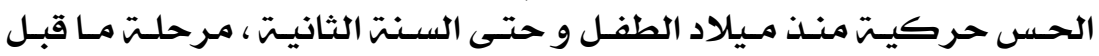

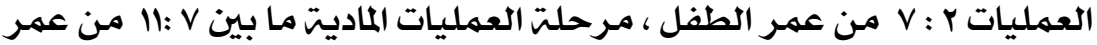

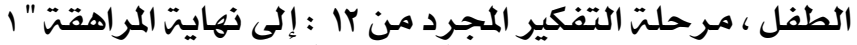

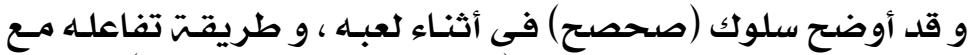

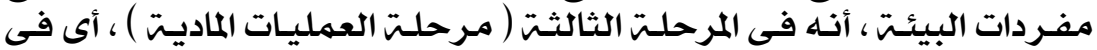

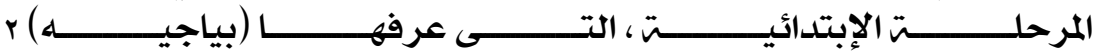

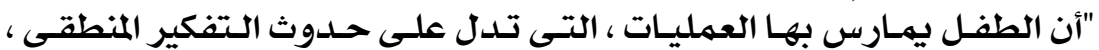

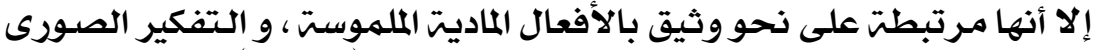

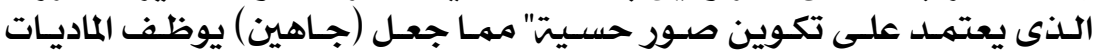

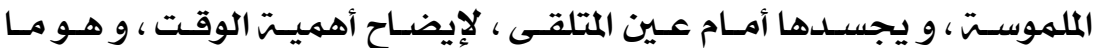

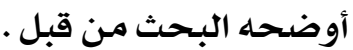
و أهم ما يميزتلك المثن من قيلت

\section{اـ الانتقال من اللفت المتمركزة حول اللذات إلى اللفت ذات}

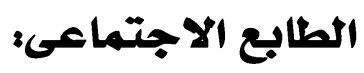

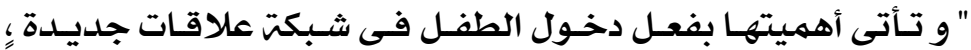

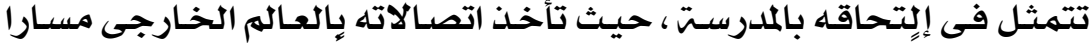

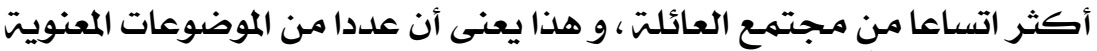

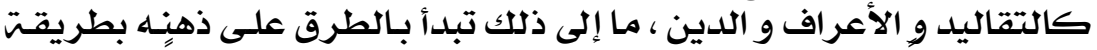

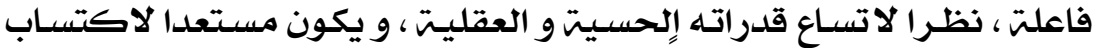

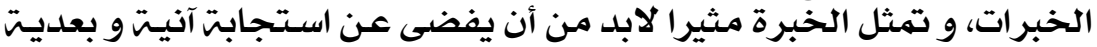

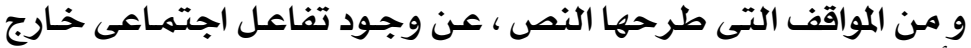

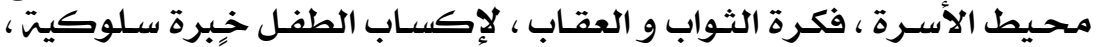

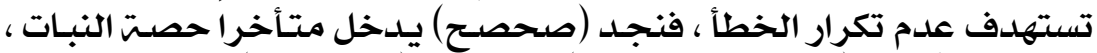

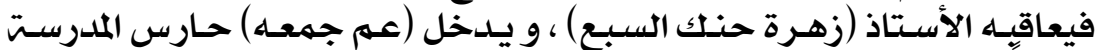

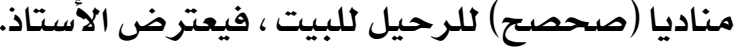

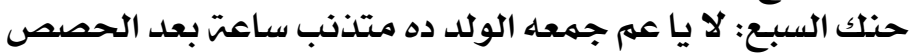

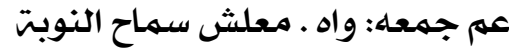

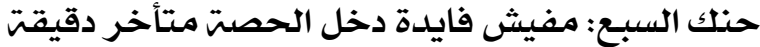

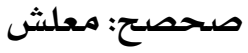

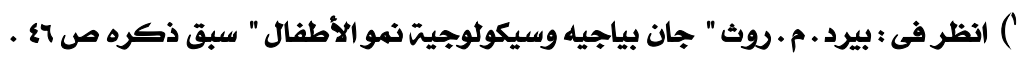

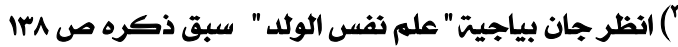

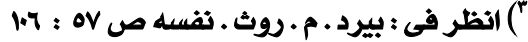

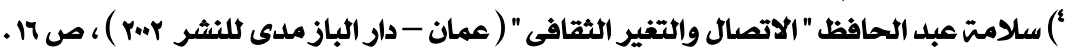


عمز جمعـه: تستاهل إللى ميلدخلش الحصتس فى الميعـاد ، علشـان ايـه يخـرج

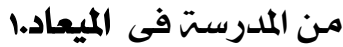

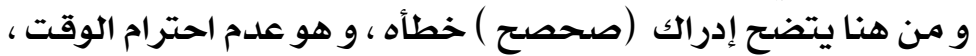

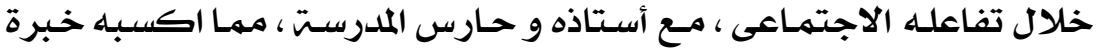

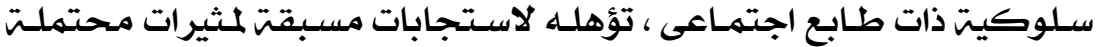
،تستهدف احترام الوقت ذاتع اجته

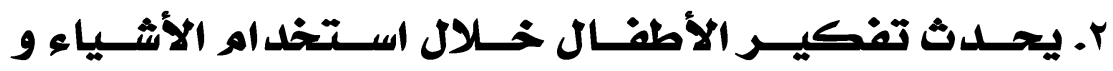

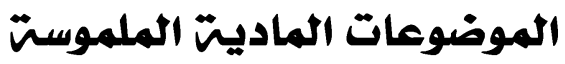

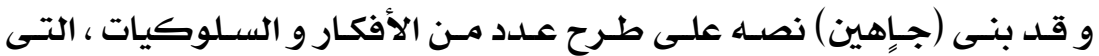

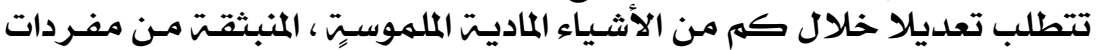

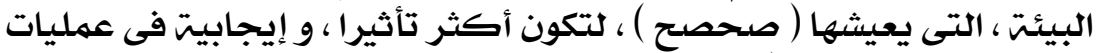

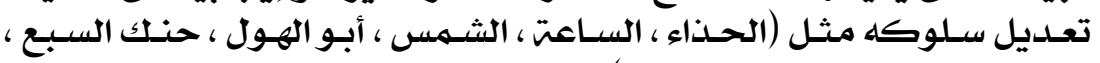

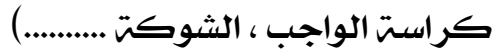

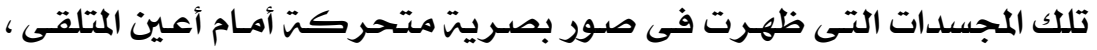

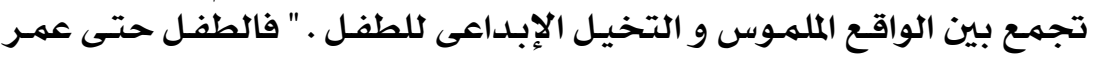

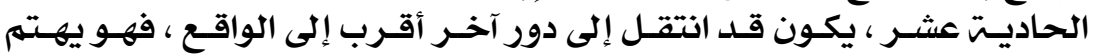

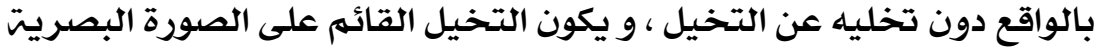

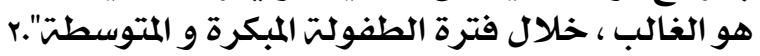

\section{r. يتطور مفهوه البقاء و الاحتفاظ كتلتّ و وزناً وحجماً ؛}

فبعد ما ينطح (صحصح) الدائرة الورقيت ، و يظهر أمـام الجههور متحسداً

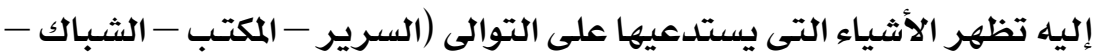

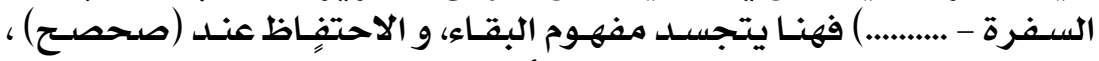

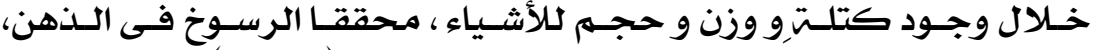

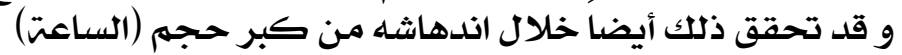

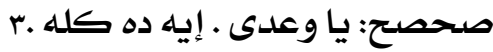

ع. تتطور عمليات التفكير فى أكثر من طريقت أو بعد واحل :

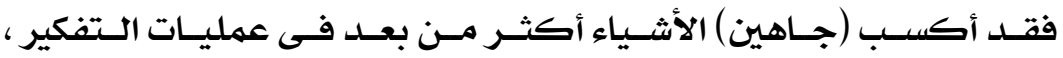

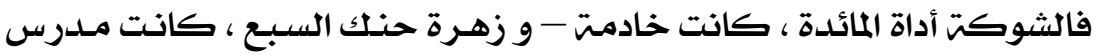

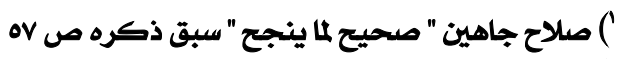

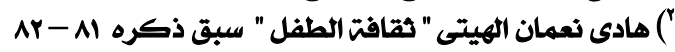

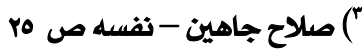




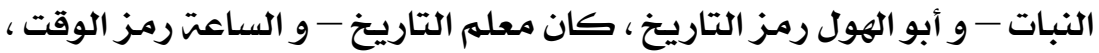

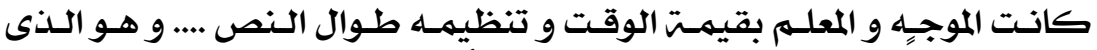

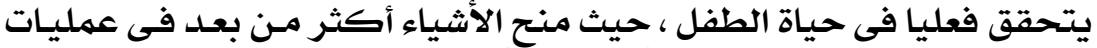

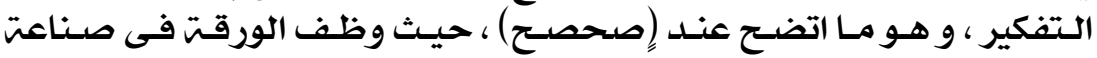
المركب ، و الحوض أحائه بحرا ، و و تخيل أفيل نفسه البحار.

\section{0.تتطور عمليات التجميع و التصنيف و تكوين المفاهيم :}

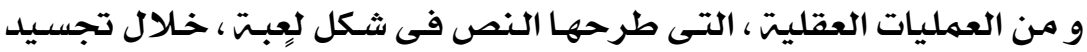

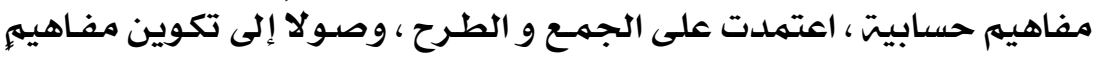

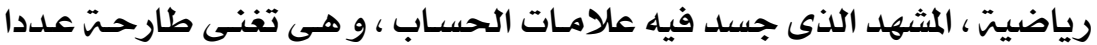

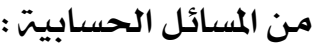

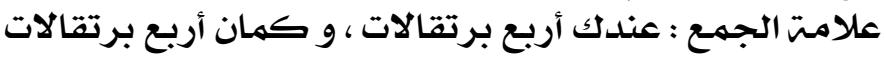

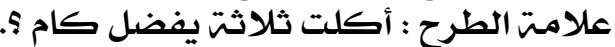

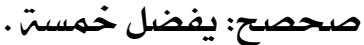

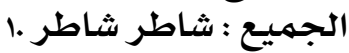

\section{7. فشـل التفكيـر فـى الاحتمـالات المسـتقبليت دون خبـرة}

\section{مباشرة بالموضوعات الماديت}

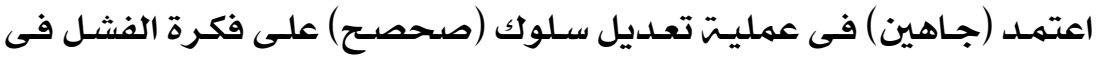

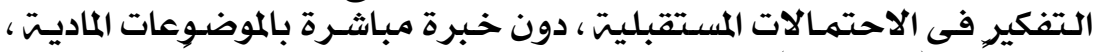

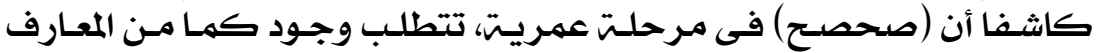

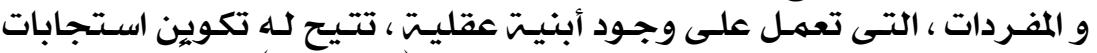

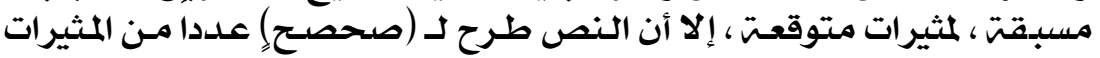

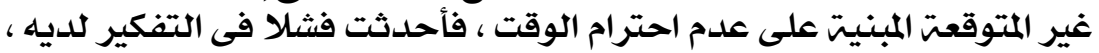

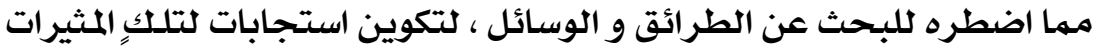

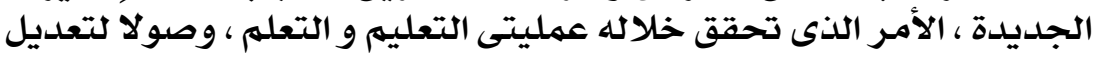

\section{V. يتطور مفهوم المقلوبيت (المعكوسيت) :}

فخلال رحلت النص ، حدث تطور لدى (صحصح) فى عمليت النهـو المعرفى ،

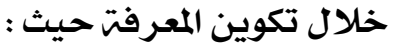

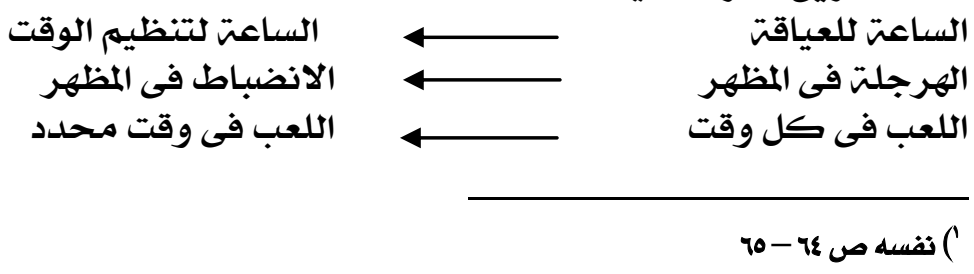




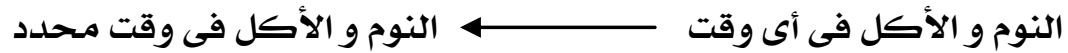

$$
\begin{aligned}
& \text { الحوض و القاذورات }
\end{aligned}
$$

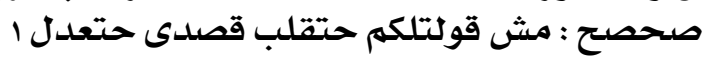

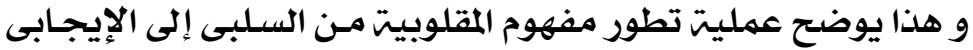

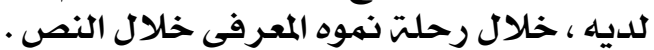

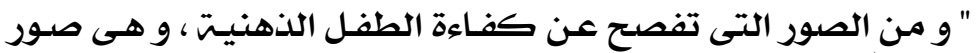

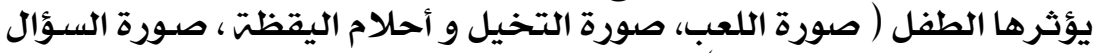

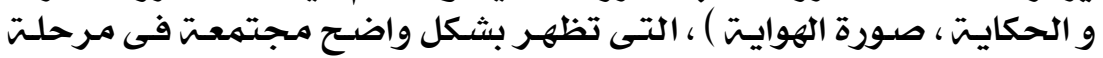

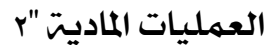

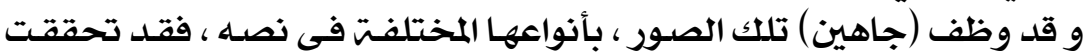

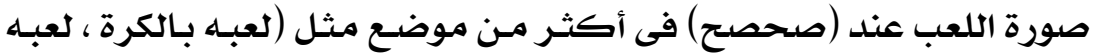

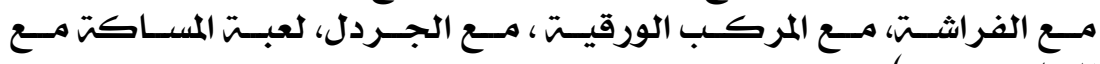

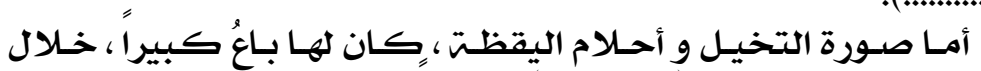

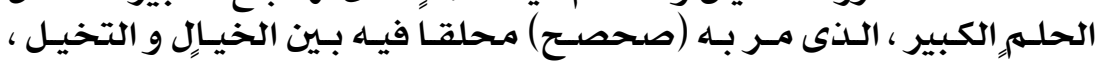

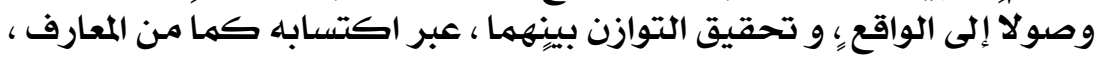

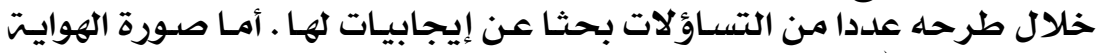

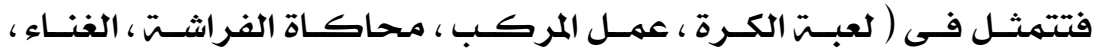
الحركات البهلوانيت.......... ).

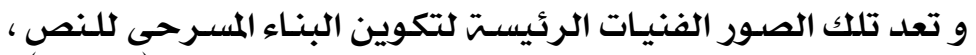

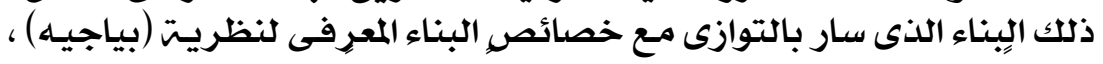

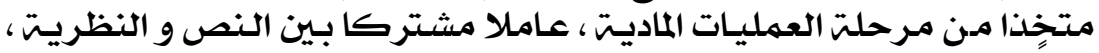

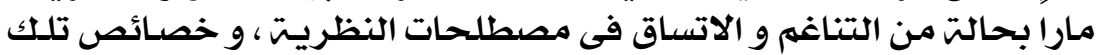

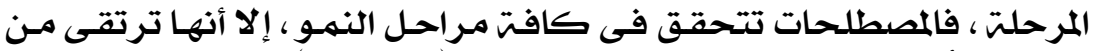

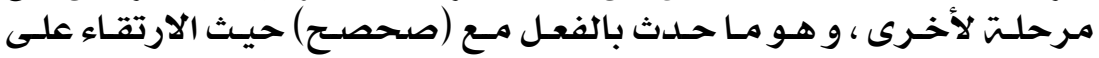

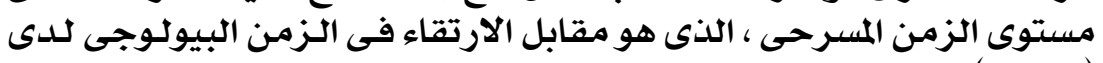

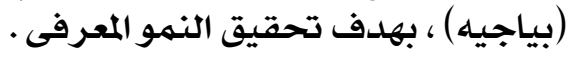

المبحث الثانى :

\section{أولاً : دلالات التشابك بـين التراث و الحداثت فى (صحصـ}

لما ينجج)

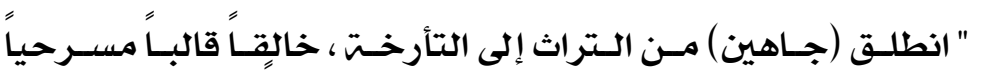

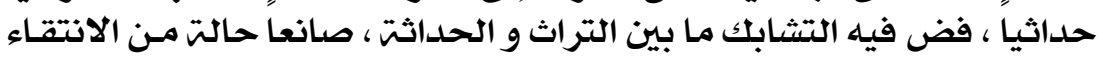

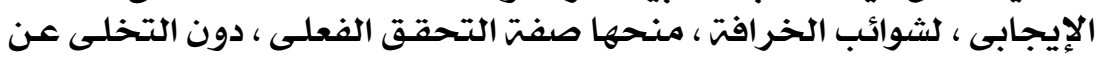

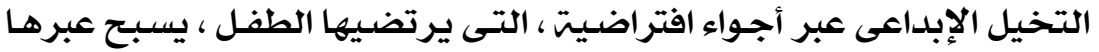

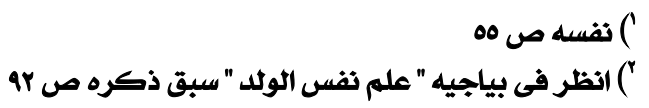




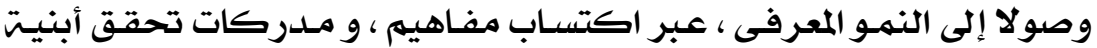

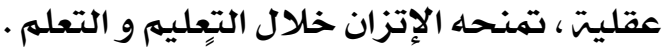

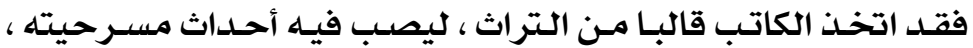

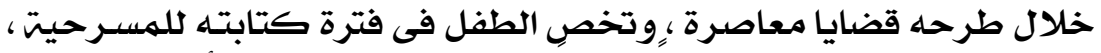

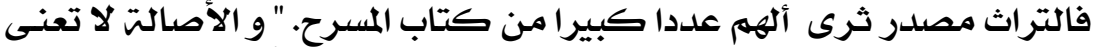

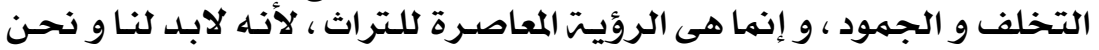

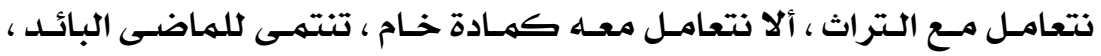

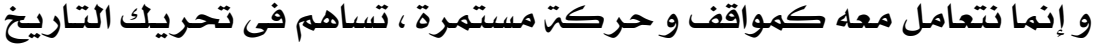

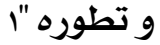

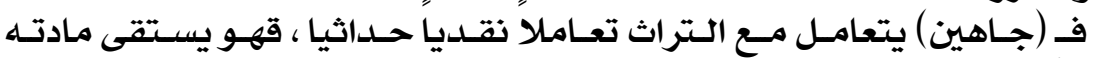

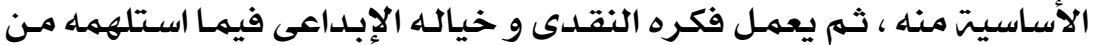

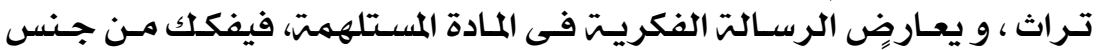

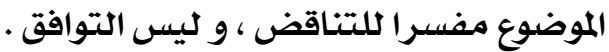

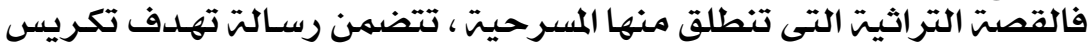

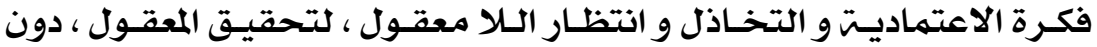

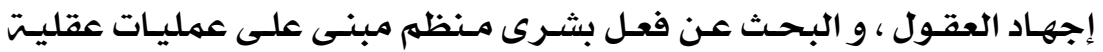

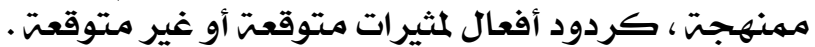

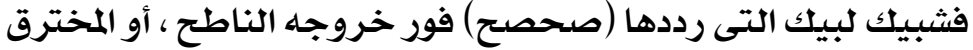

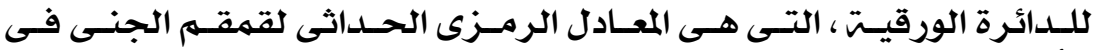

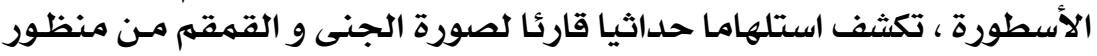

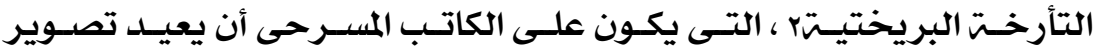

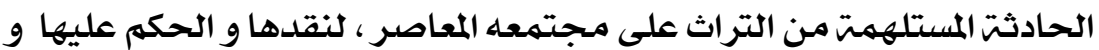

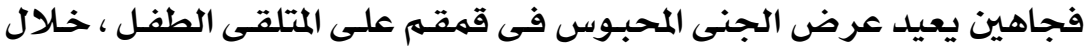

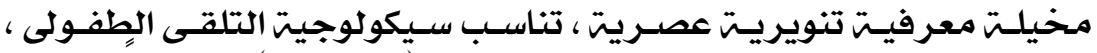

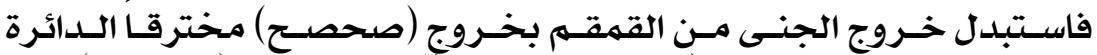

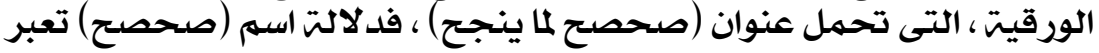

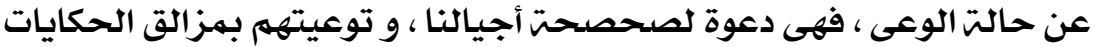

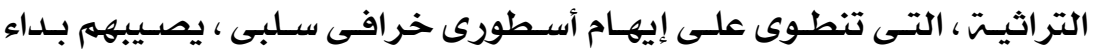

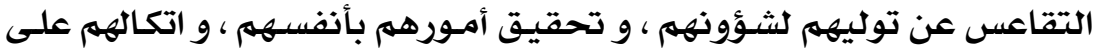

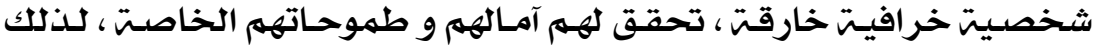

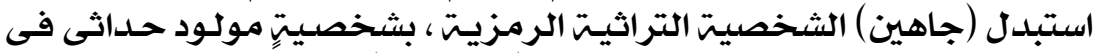

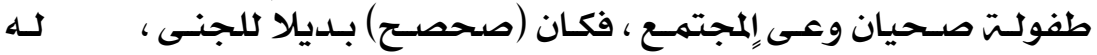

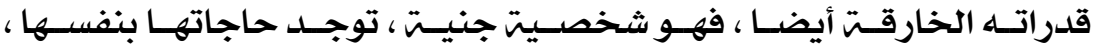

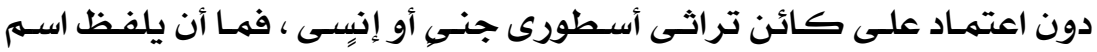

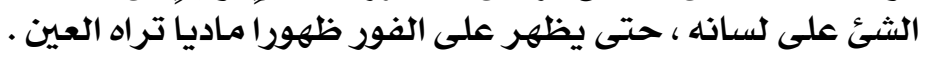

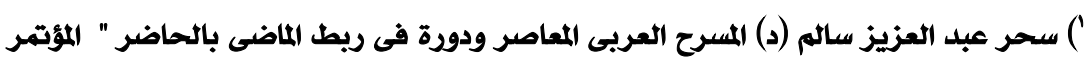

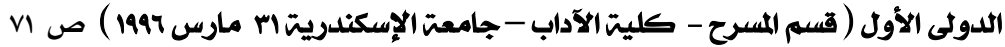

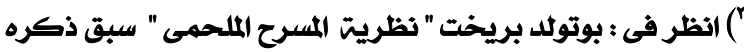


(فى أثناء كام صحصح تظهر الأثياء التى يذكر ها على التـوالى سـرير -

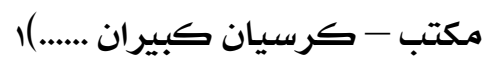

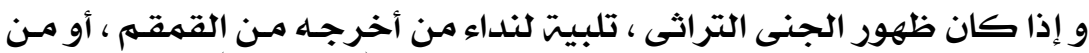

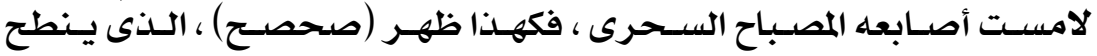

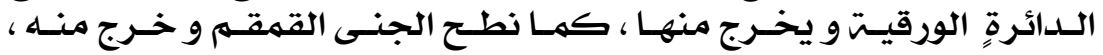

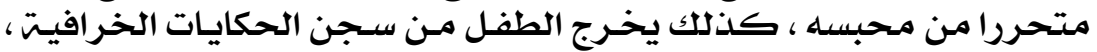

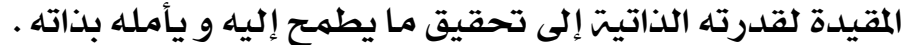

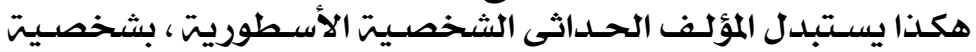

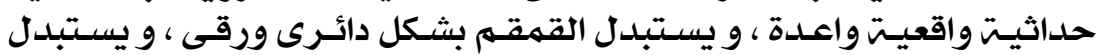

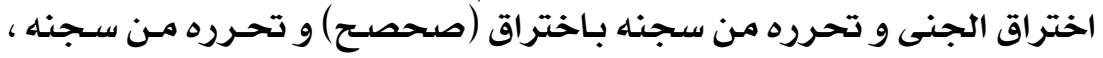

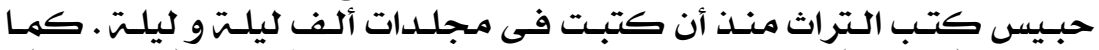

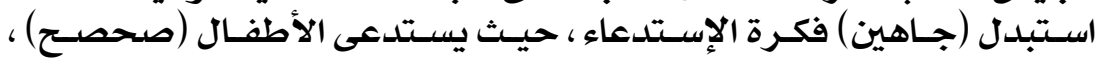

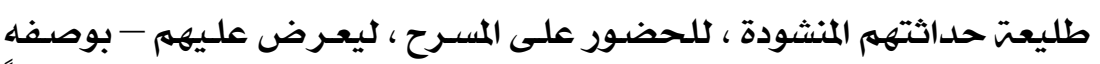

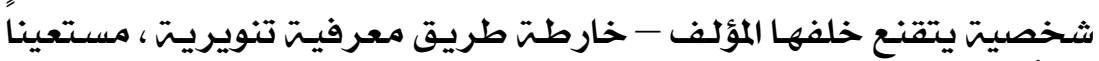

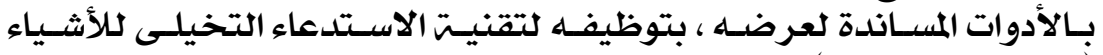

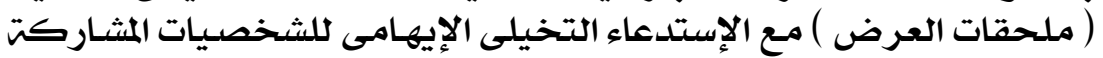

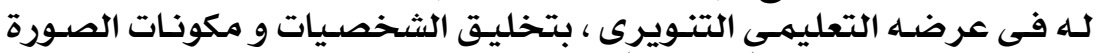

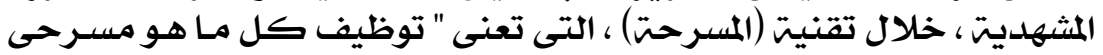

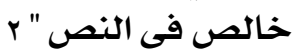

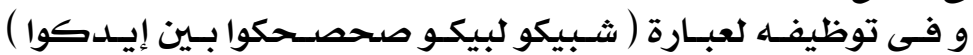

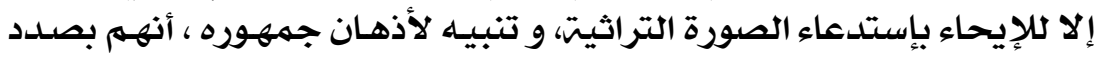

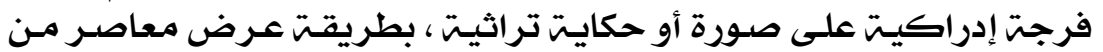

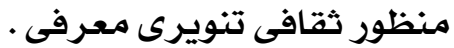

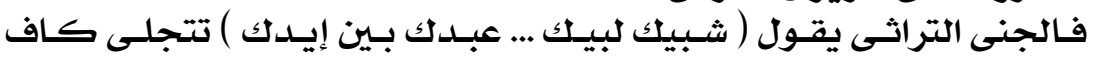

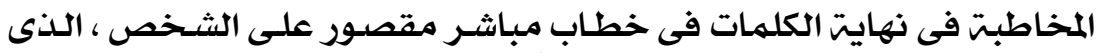

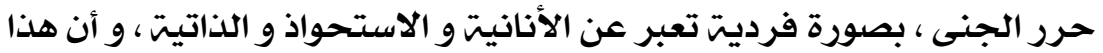

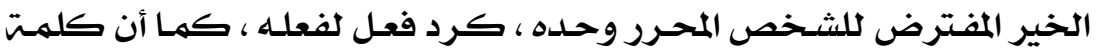

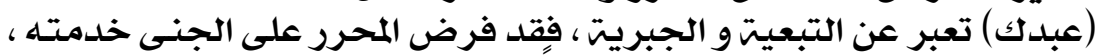

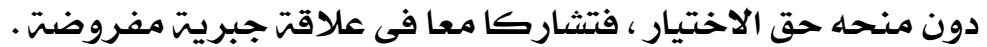

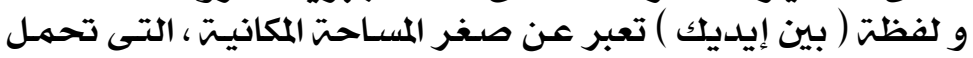

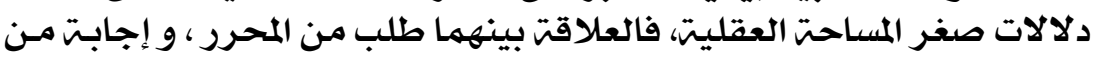

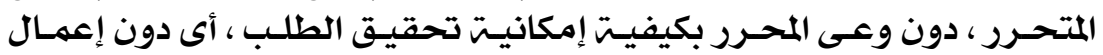

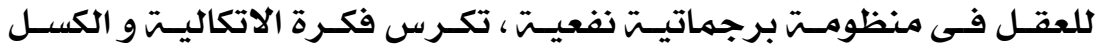

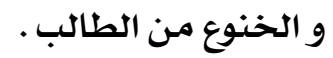

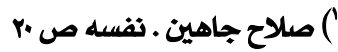

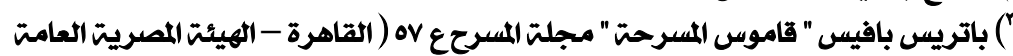
Vع ، للكتاب أغسطس بافيس " 


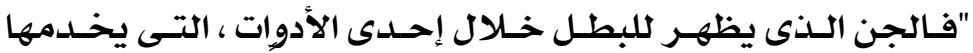

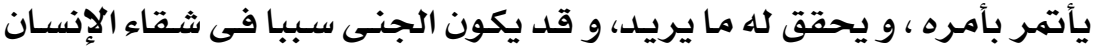
أو سعادته" أتهر بأمره ،

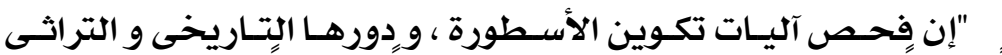

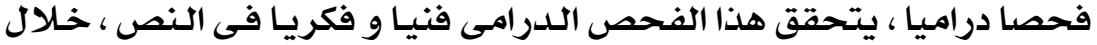

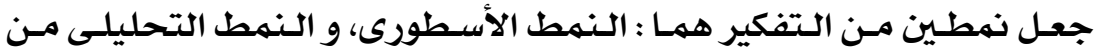

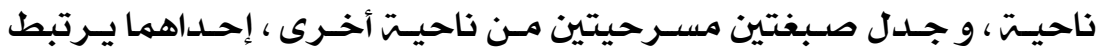

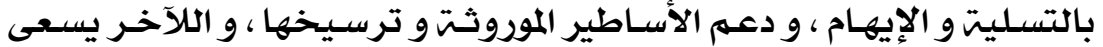

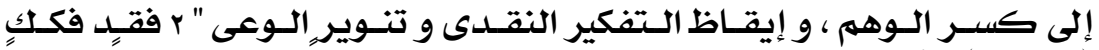

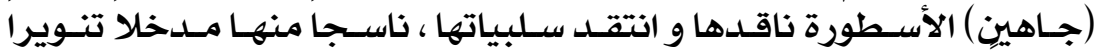

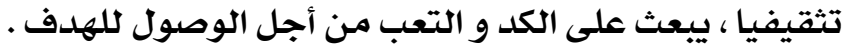

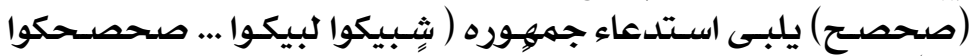

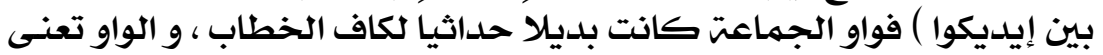

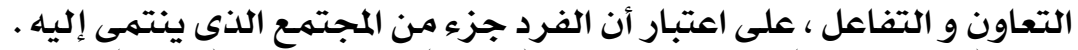

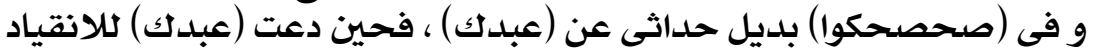

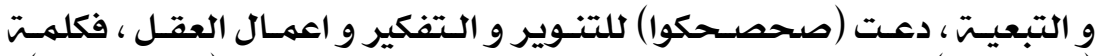

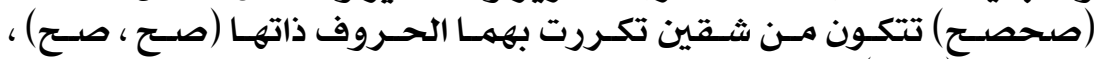

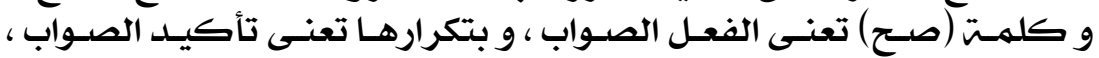

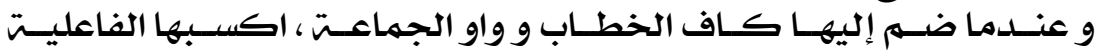

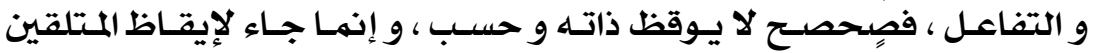

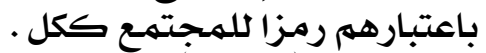

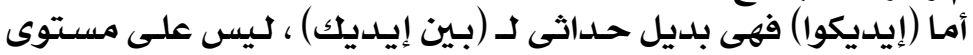

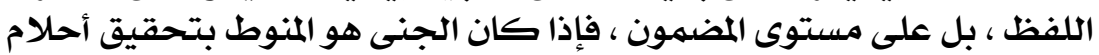

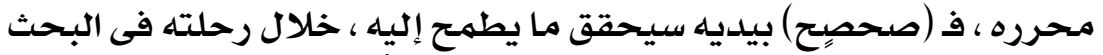

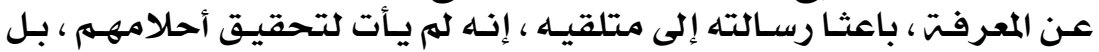

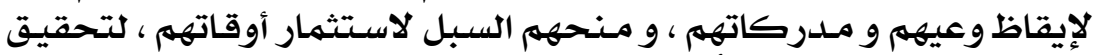

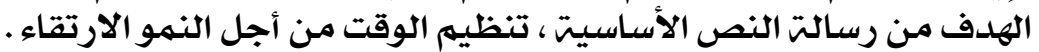

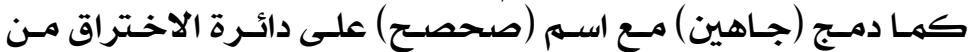

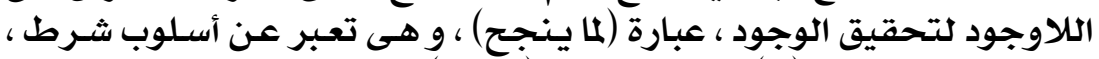

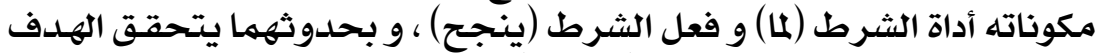

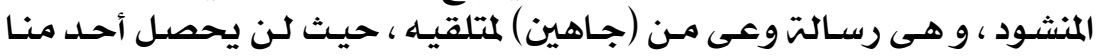

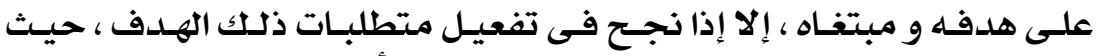

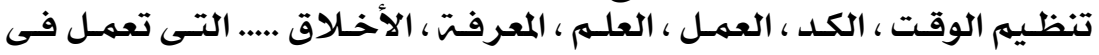

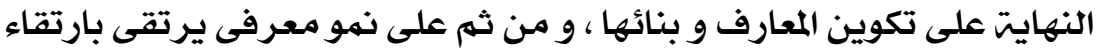

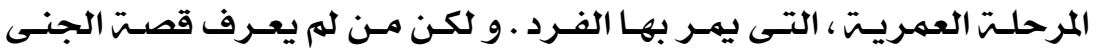

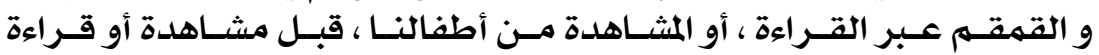

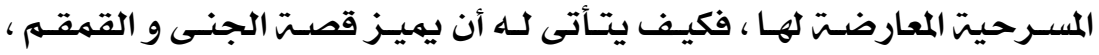

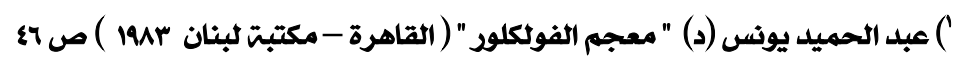

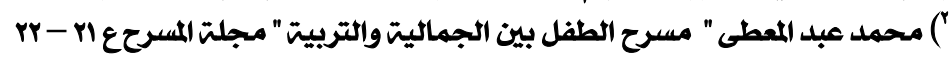

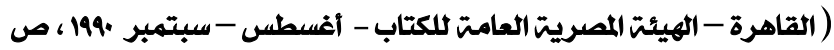




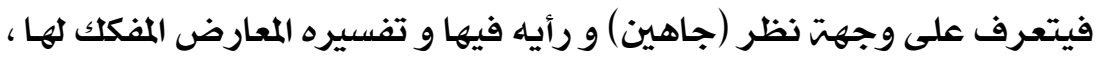

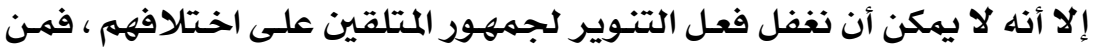

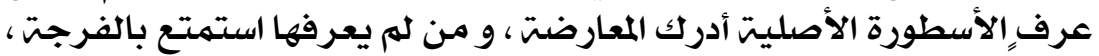

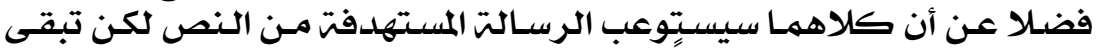

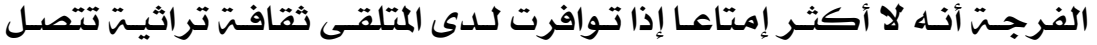
بموضوع المسرحيت أنه

\section{ثانياً : البناء اللد رامى ودوره فى تكوين البناء المعرفى فى (صحصح لما ينجح)}

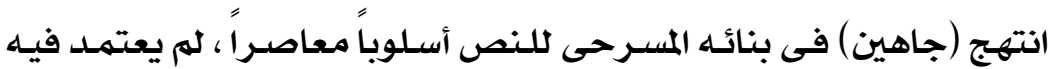

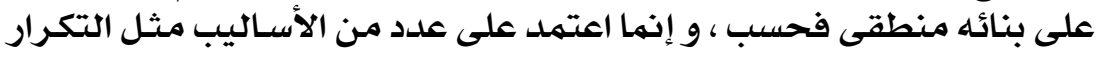

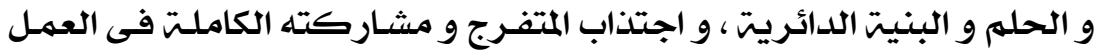

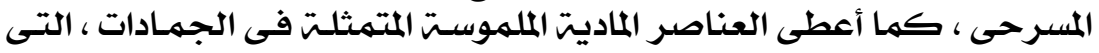

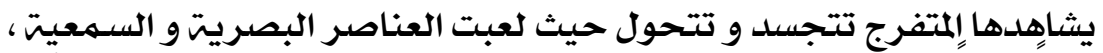

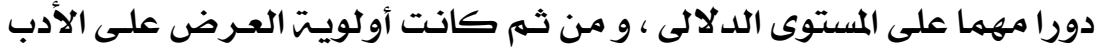

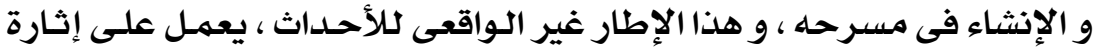

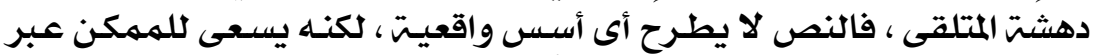

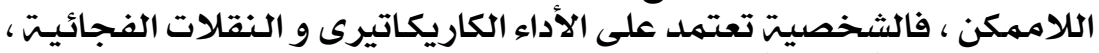

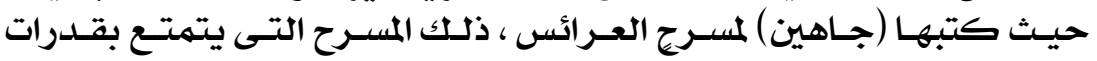

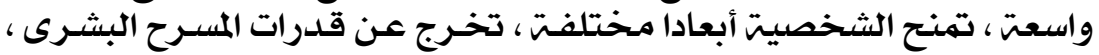

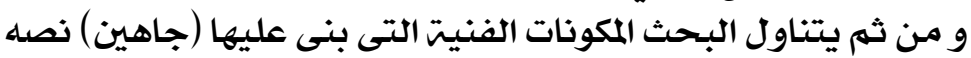

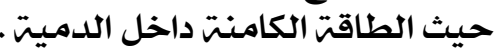

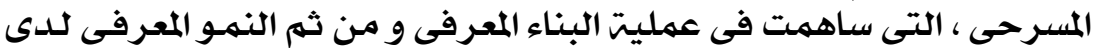
(صحصح) و متلقيه . (التى .

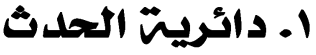

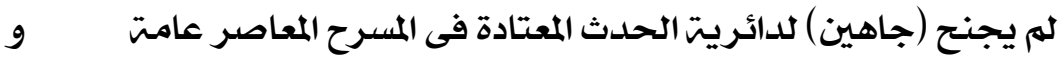

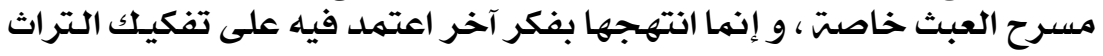

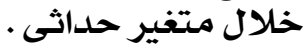

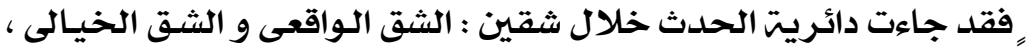

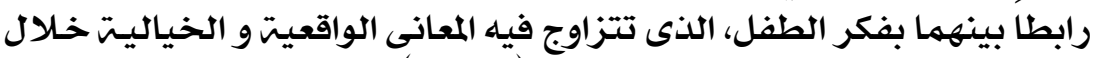

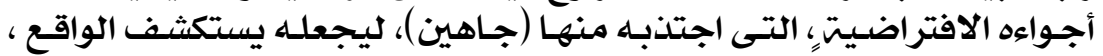

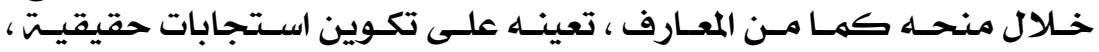

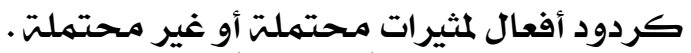

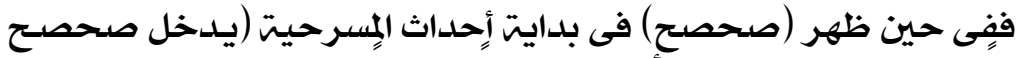

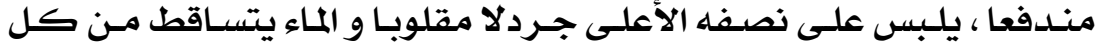


جسمهه و ملابسـه ، و صحصح يتكلهم من داخل الجردل فى حالتّ مـن الاسـتياء

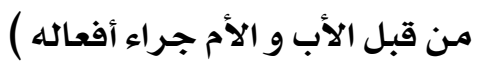

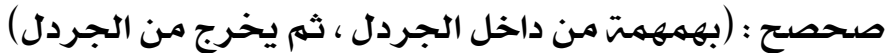

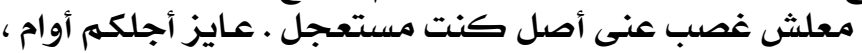

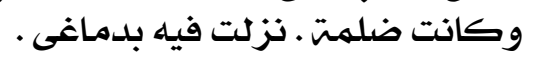

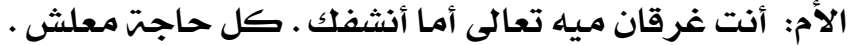

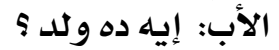

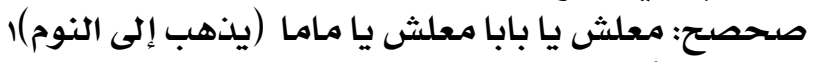

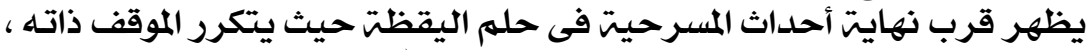

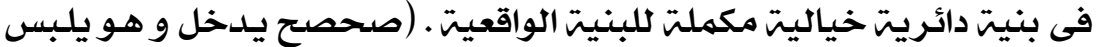

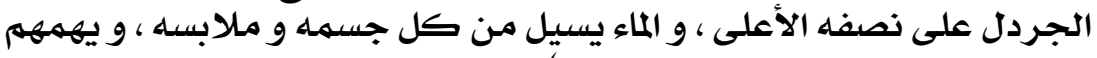

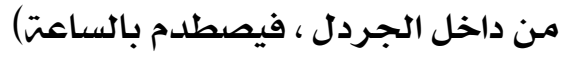

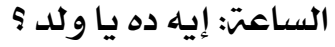

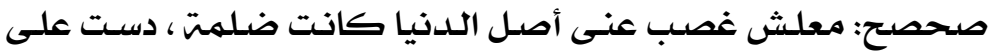

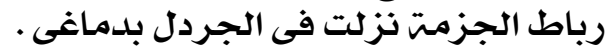

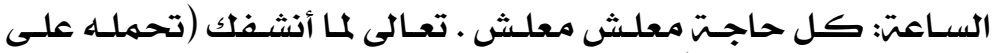

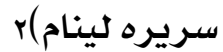

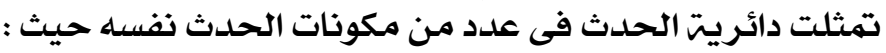

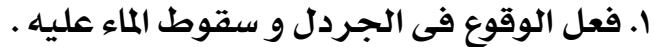

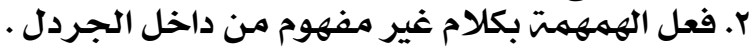

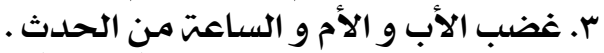

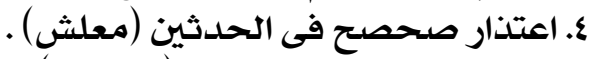

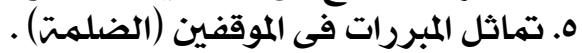

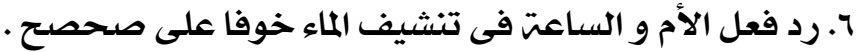

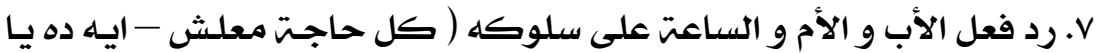

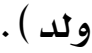

$$
\text { و 1. الذتلف الحدل للنوم فى الحالتين . }
$$

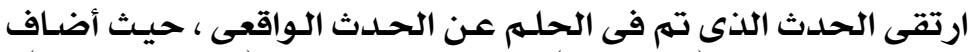

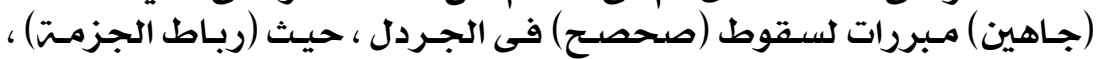

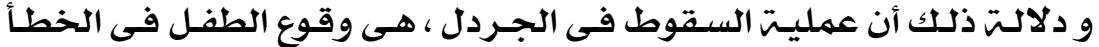

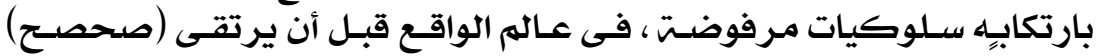

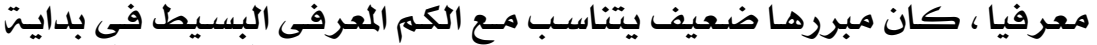

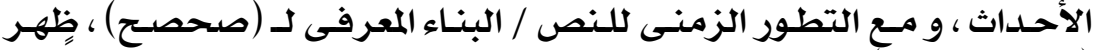

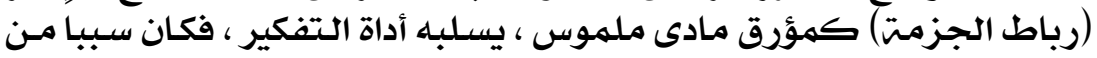
أسباب سقوطه . 


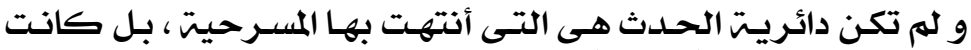

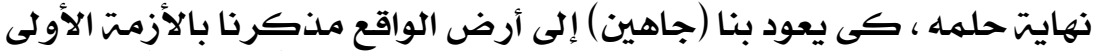

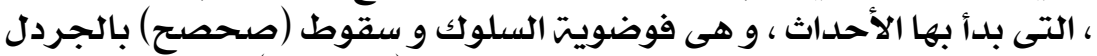

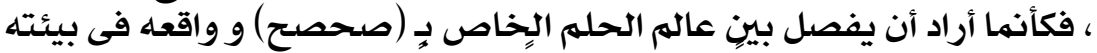

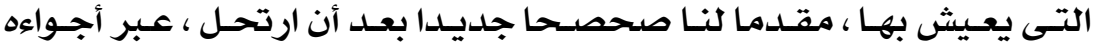

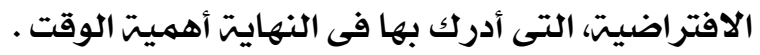

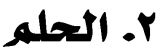

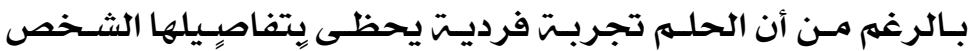

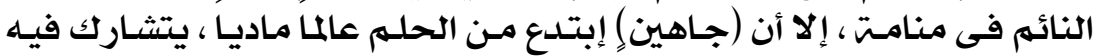

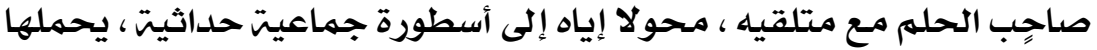

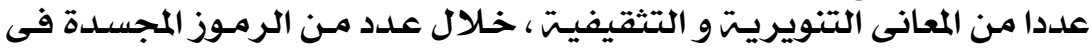

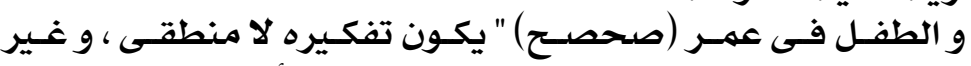

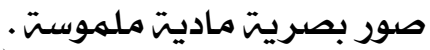

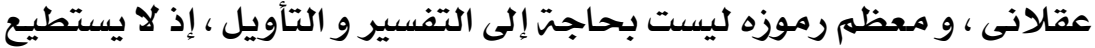

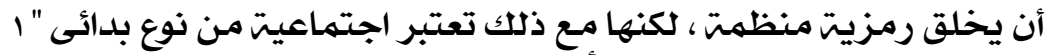

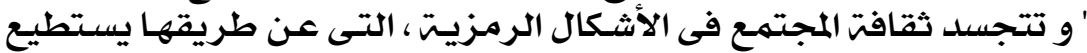

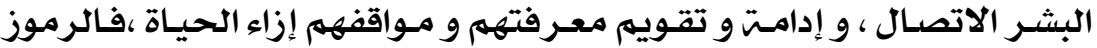

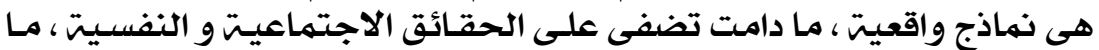

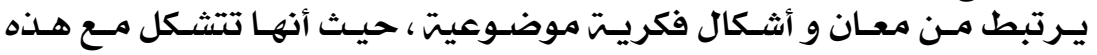

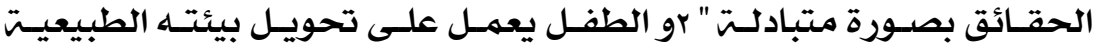

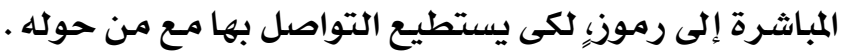

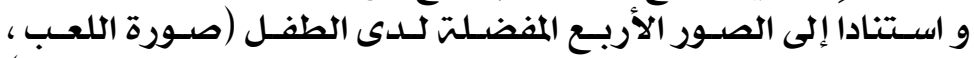

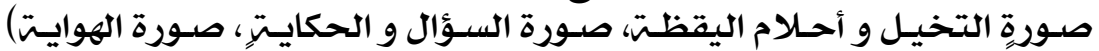

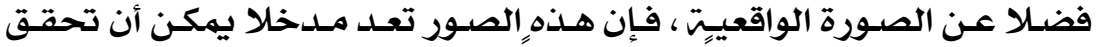

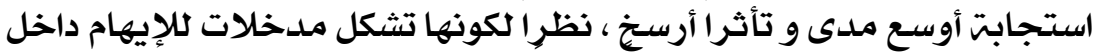

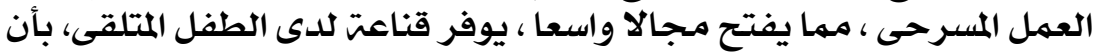

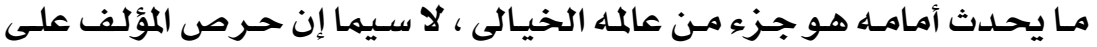

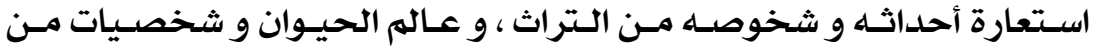

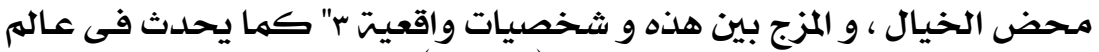

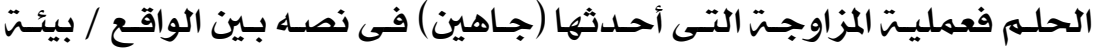

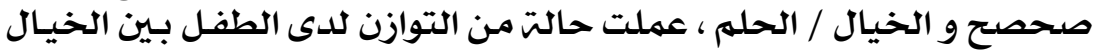

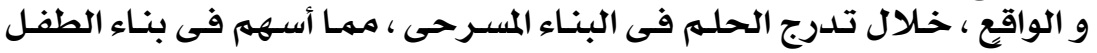

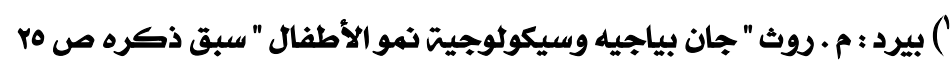

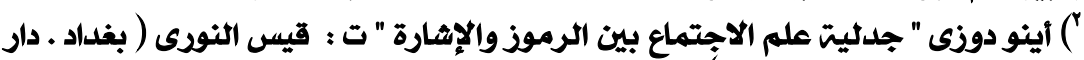

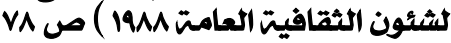

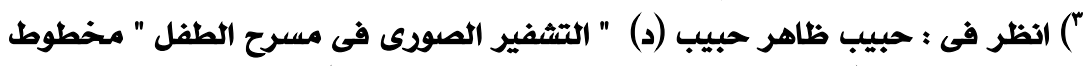

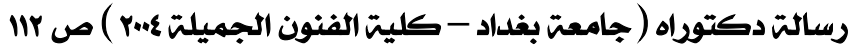




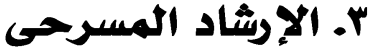

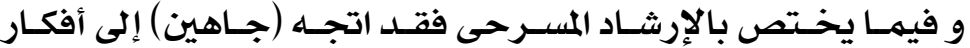

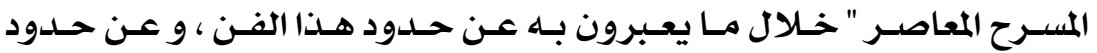

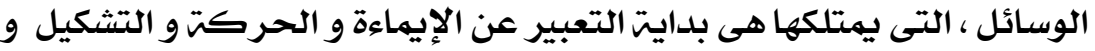

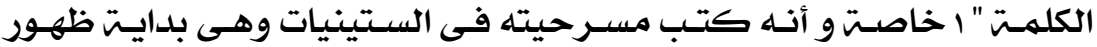

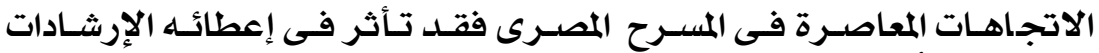

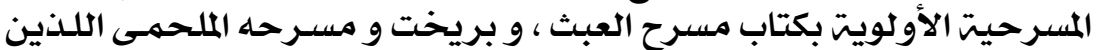

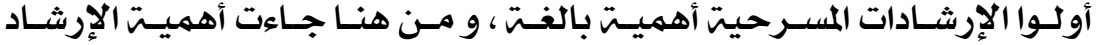

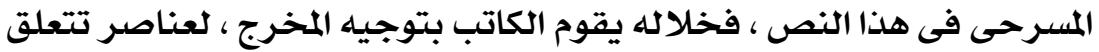

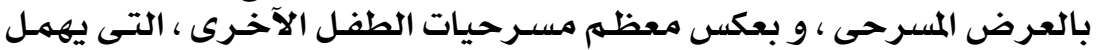

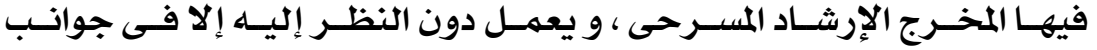

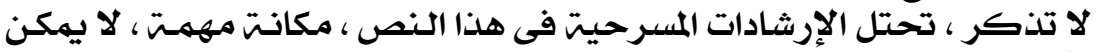

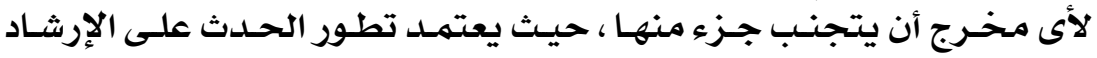

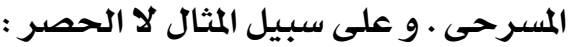

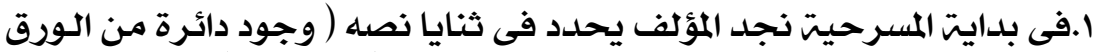

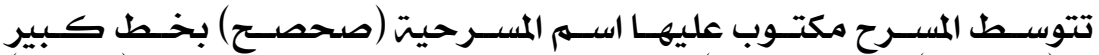

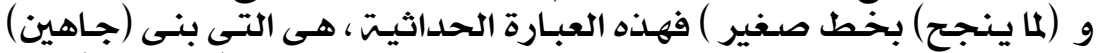

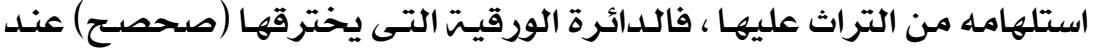

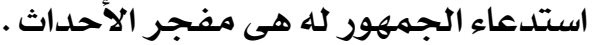

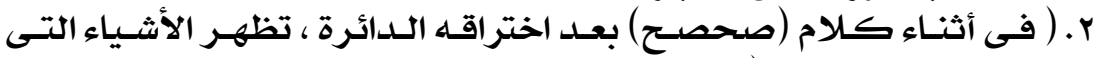

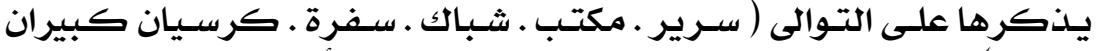

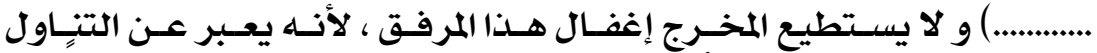

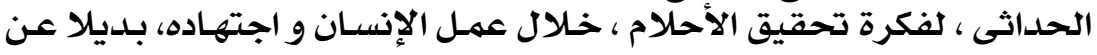

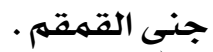

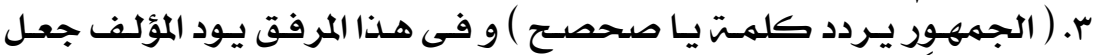

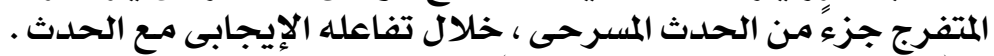

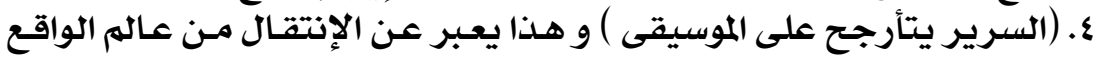

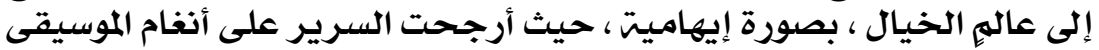

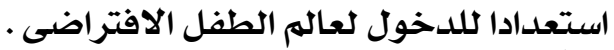

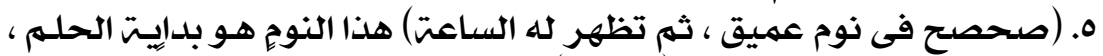

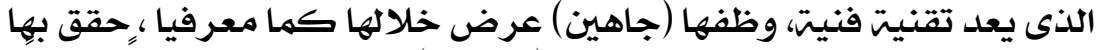

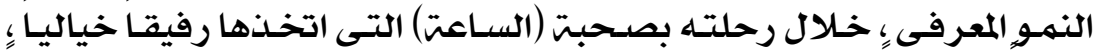

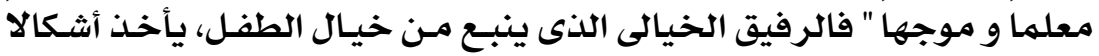

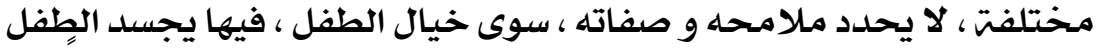

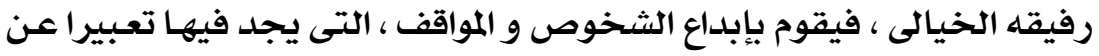

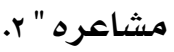

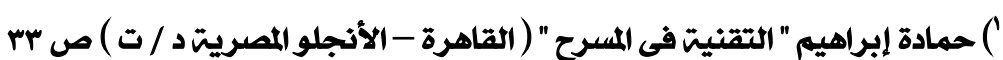

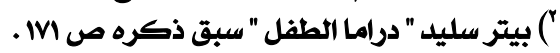
$11 \mathrm{~T}$ 


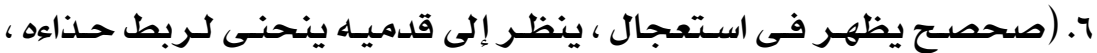

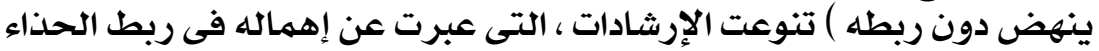

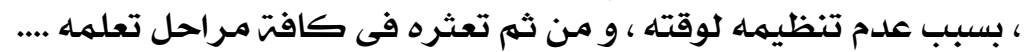

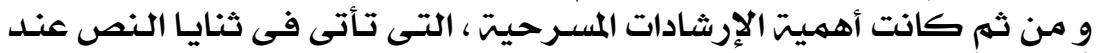

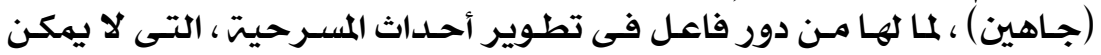

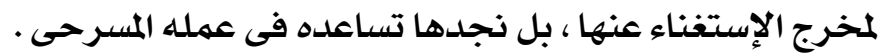

\section{ثالثاً ء أنسنت الحيوان و الجماد وتوظيفهما}

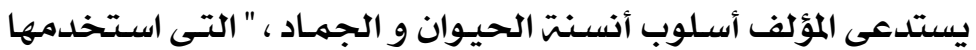

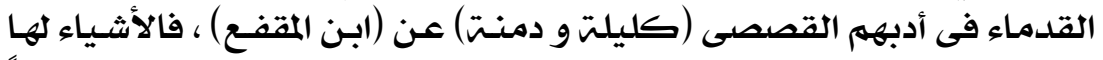

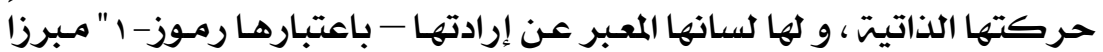

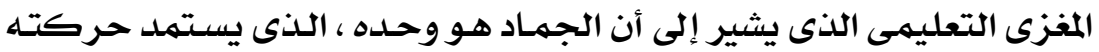

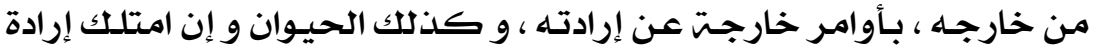

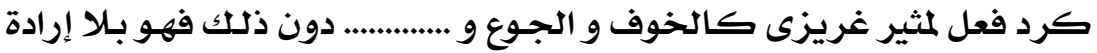

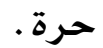

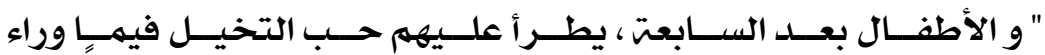

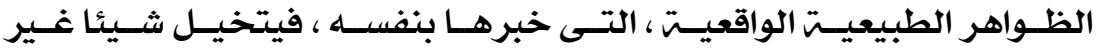

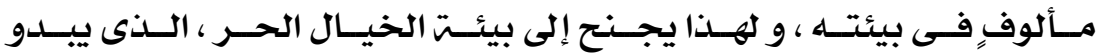

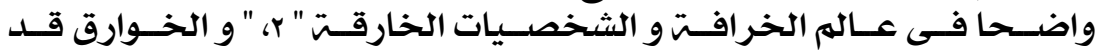

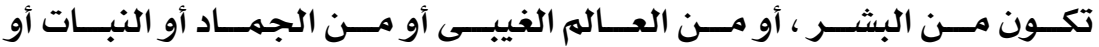

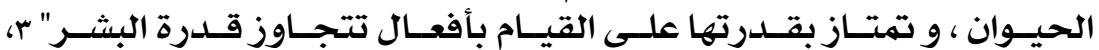

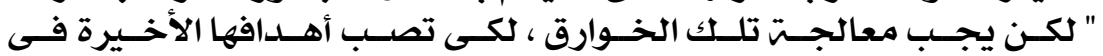

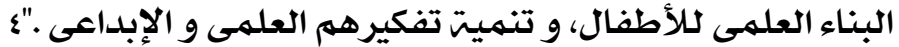

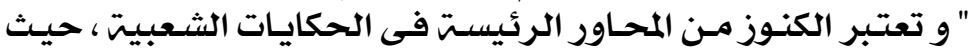

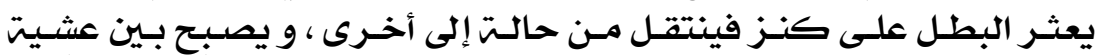

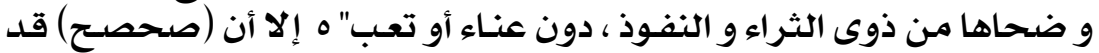

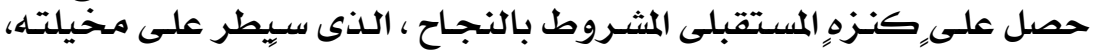

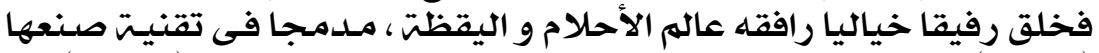

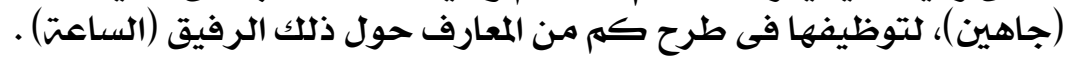

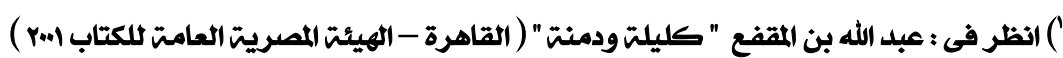

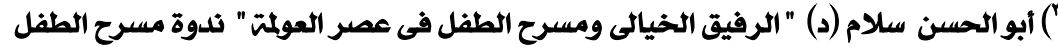

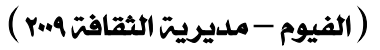

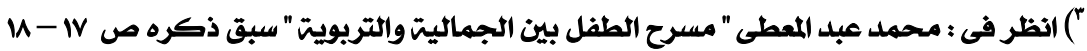

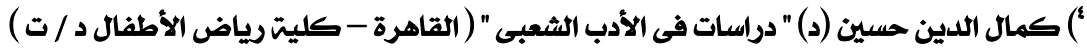

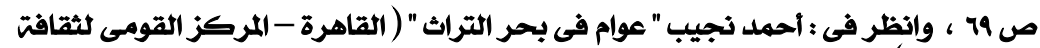

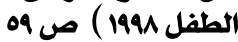
( ) عبد الحميد يونس " معجم الفوكلور " سبق ذكره ص 


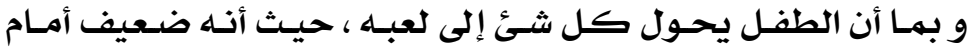

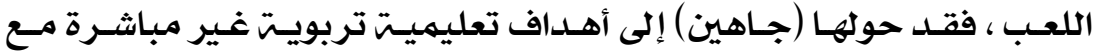
التركيز على العناصر المرئيت.

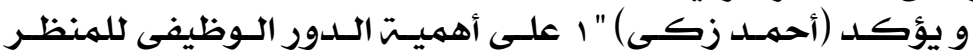

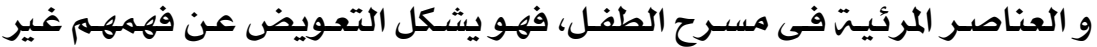

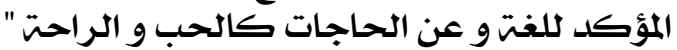

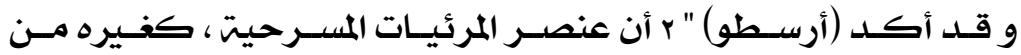

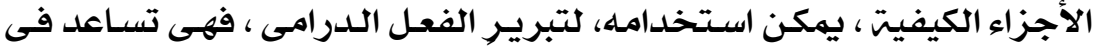

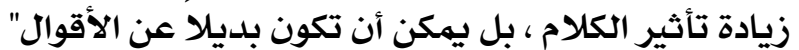

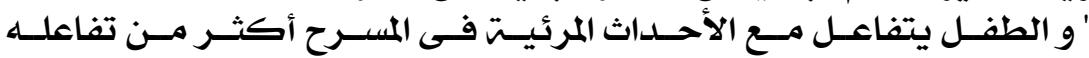

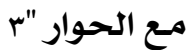
و فى مسرحيت (جاهين) تظهر قدرة عناصر التشكيل فى الفراغ المسـرحى الته

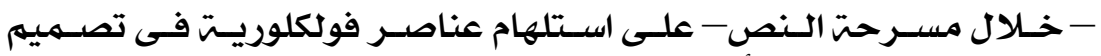

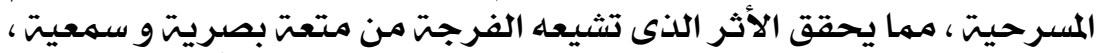

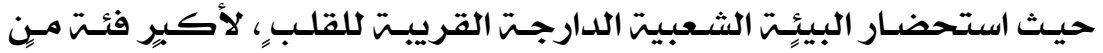

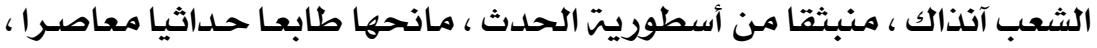

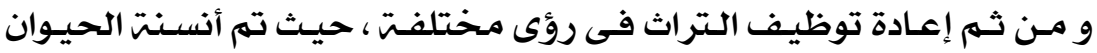

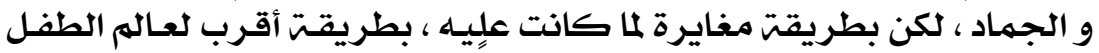

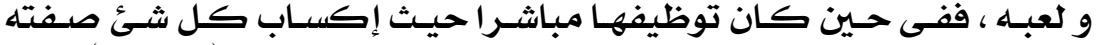

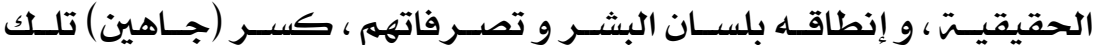

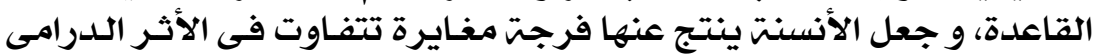

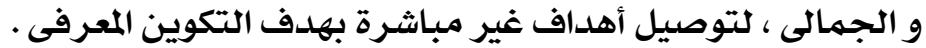

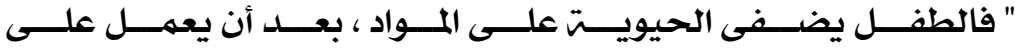

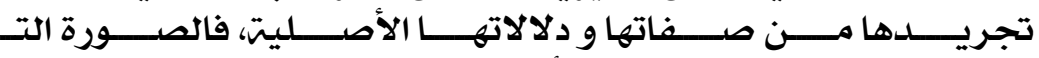

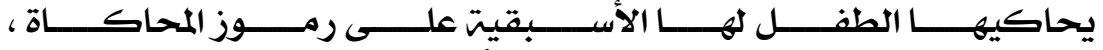

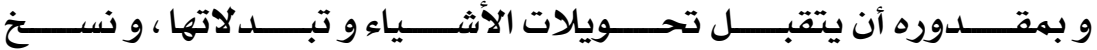

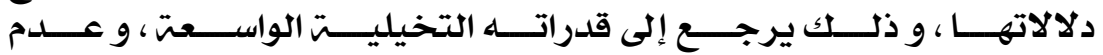

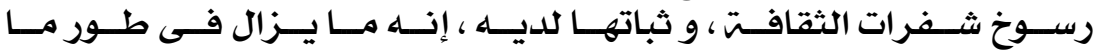

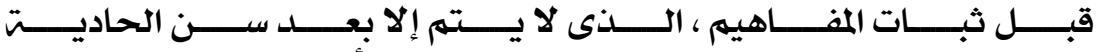

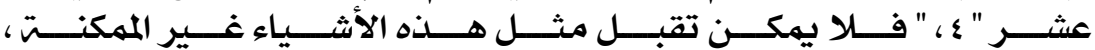

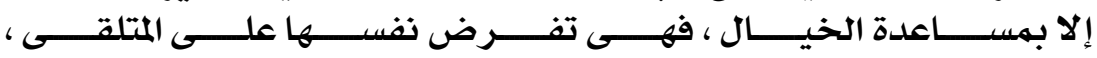

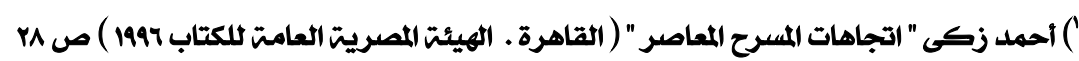

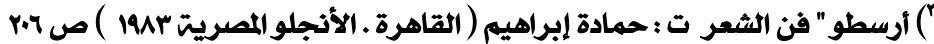

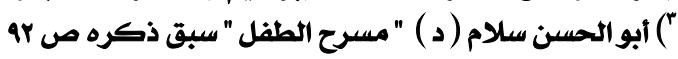

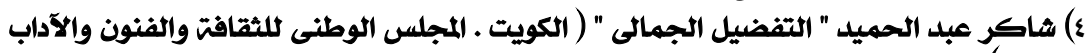

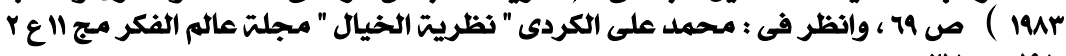
MM ص 194. 


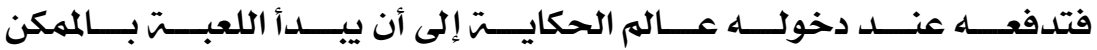

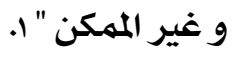

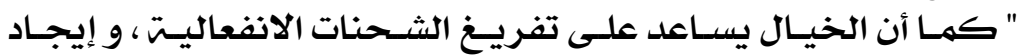

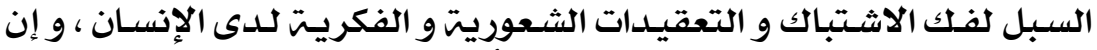

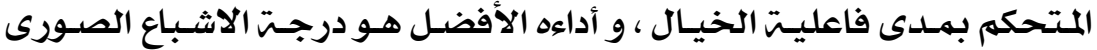

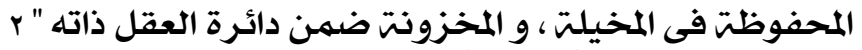

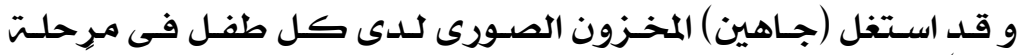

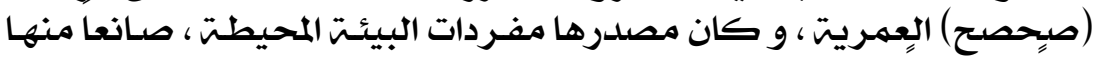

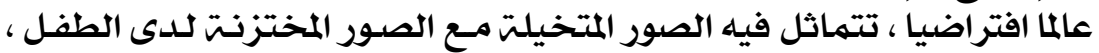

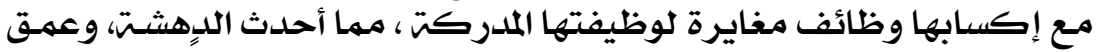

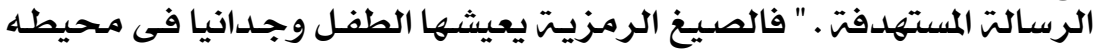

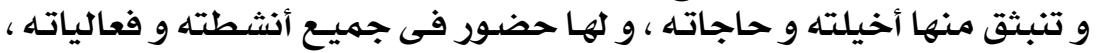

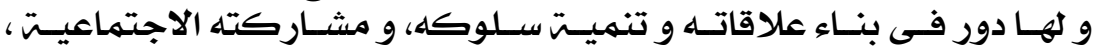

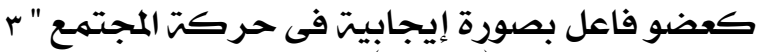

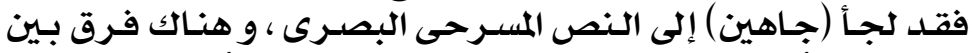

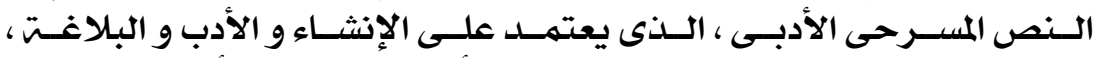

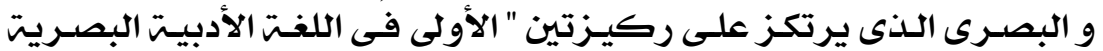

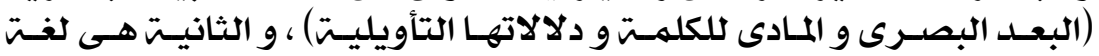

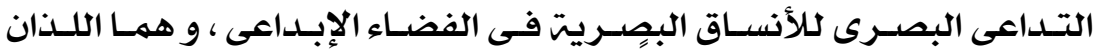

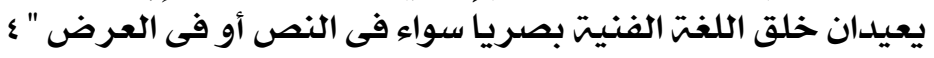

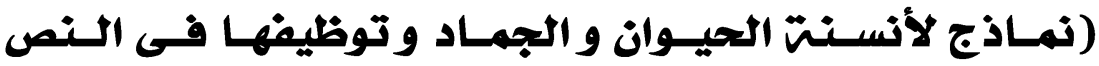

ودلالاتها)

\section{اـ الد ائرة المخترقت}

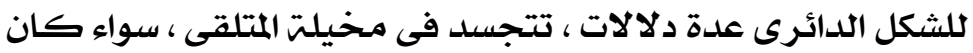

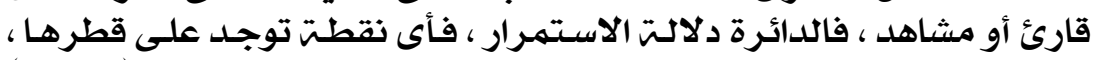

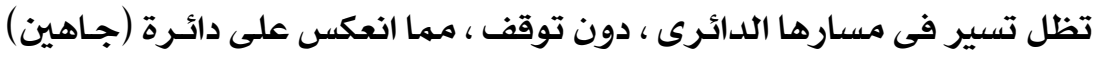

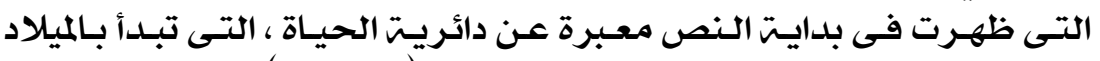

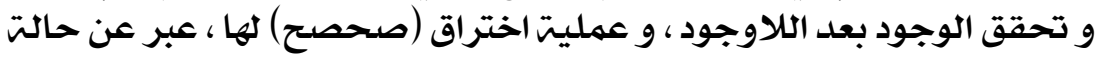

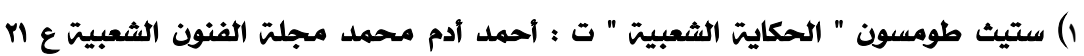

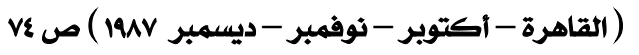

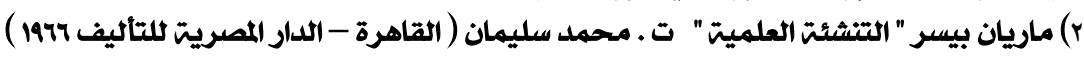
ص ماريان 1.7 ") أسعد ميخائيل " سيكولوجيت الإبداع فى الأدب والثن ( القاهرة - الهيئت المصريت

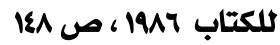

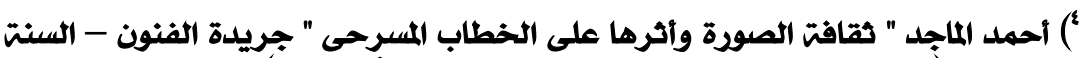

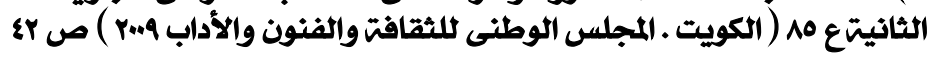




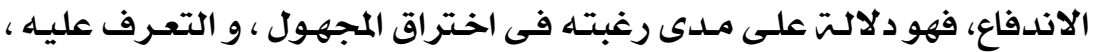

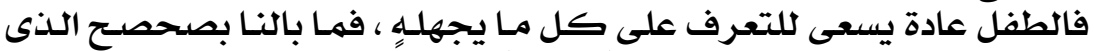

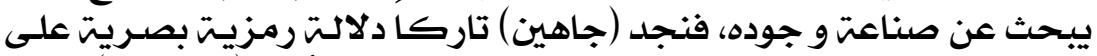

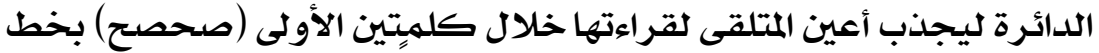

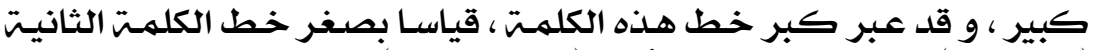

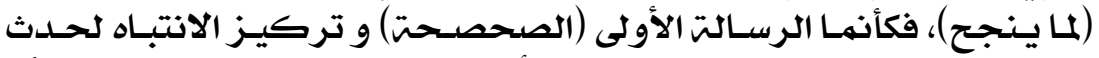

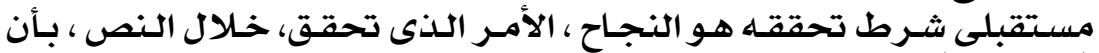

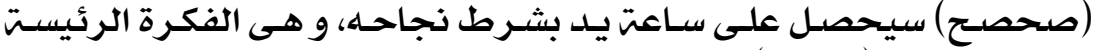

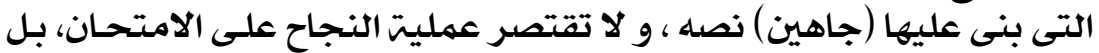

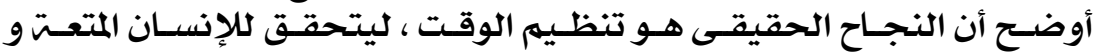

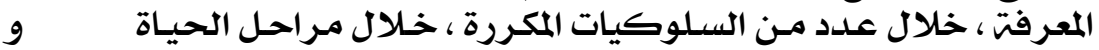

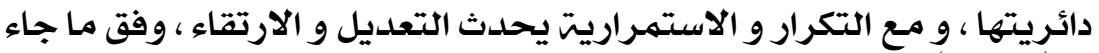

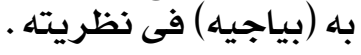

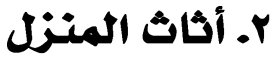

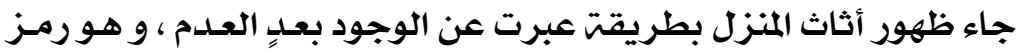

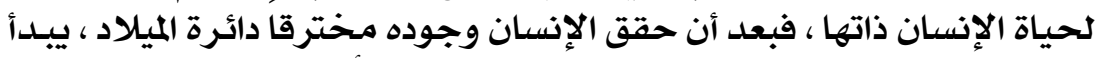

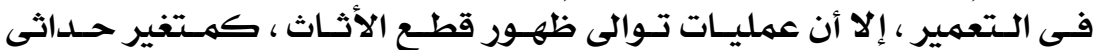

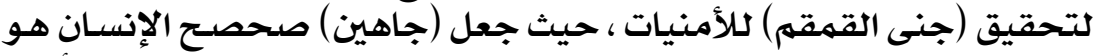

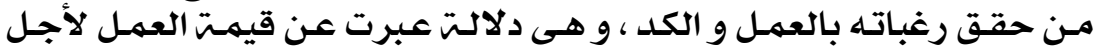

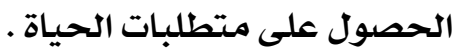

r. الشاع

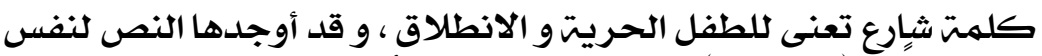

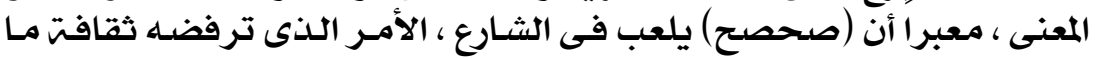

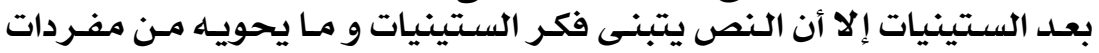
تناسب تلك الفترة .

\section{ع. السيجارة}

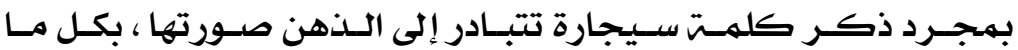

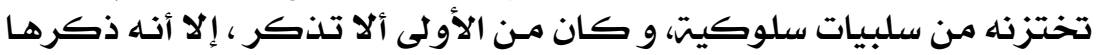

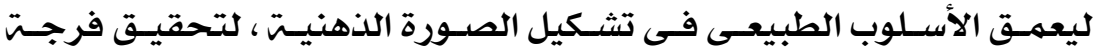

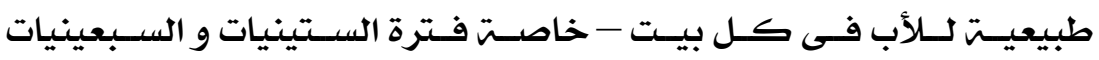

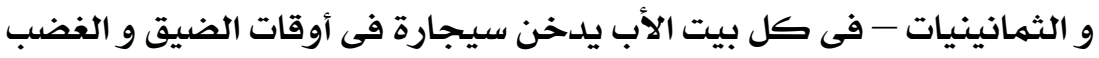

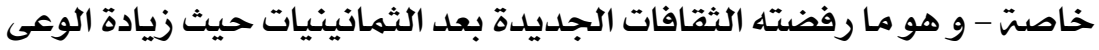




\section{0. النظارة}

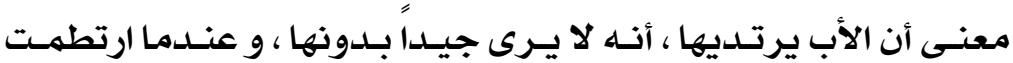

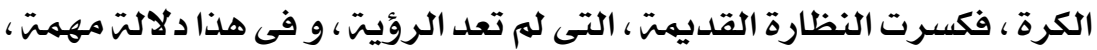

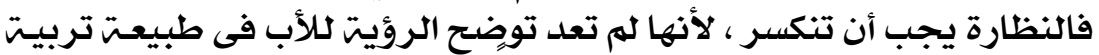

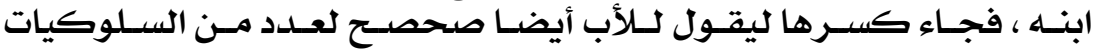

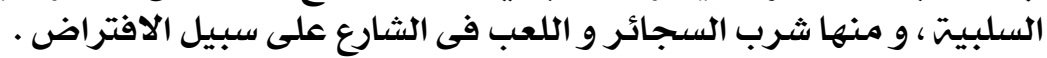

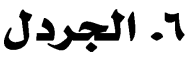

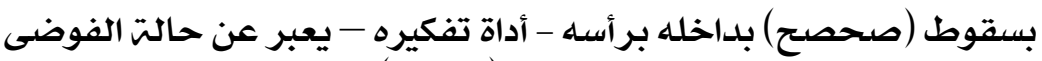

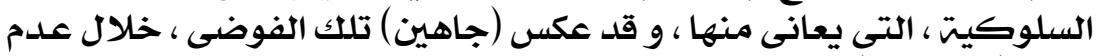

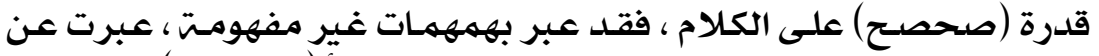

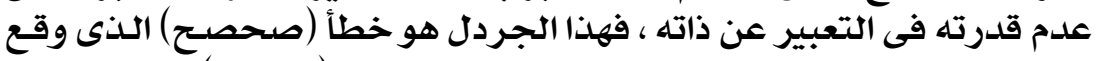

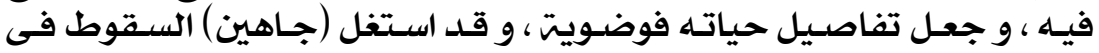

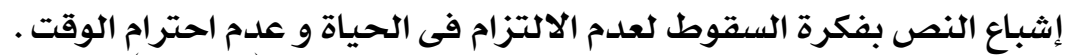

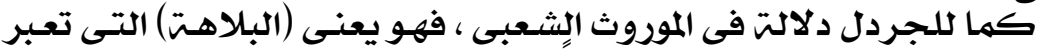

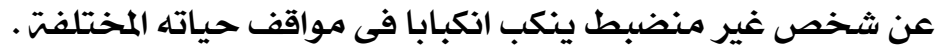

\section{V. الكرة}

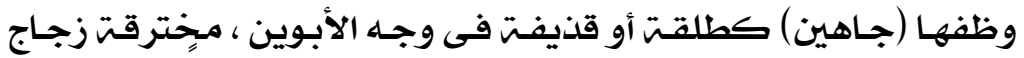

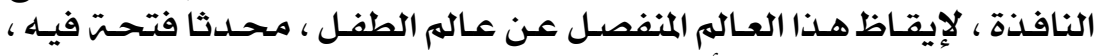

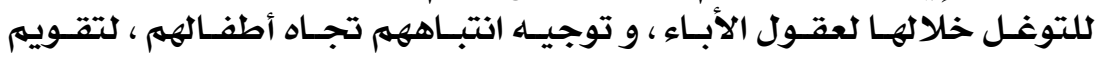

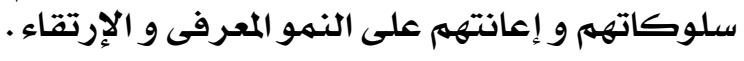

\section{1. - م. السرير المتتأرجح}

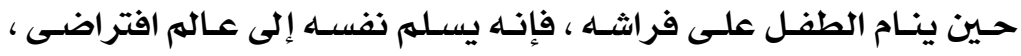

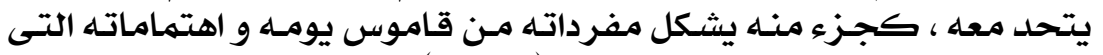

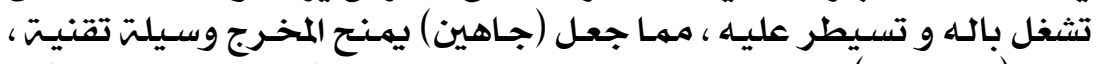

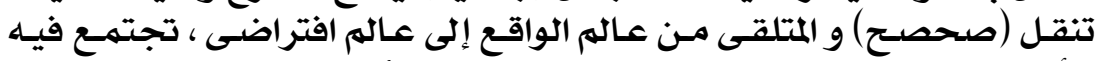

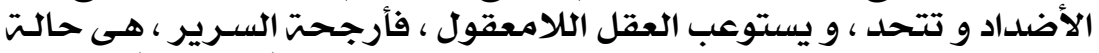

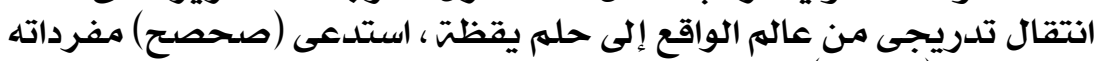

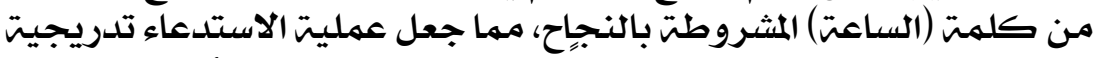

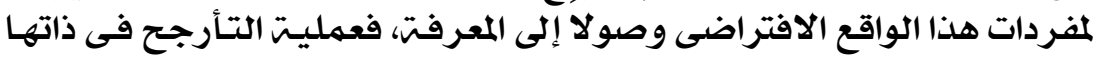

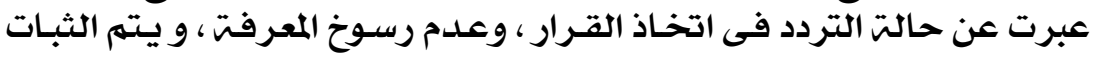

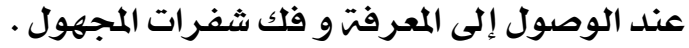




\section{9. التلفاز - الراديو - صوت المعلق}

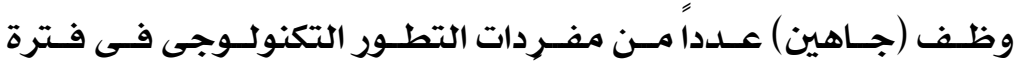

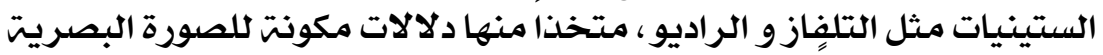

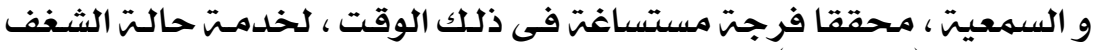

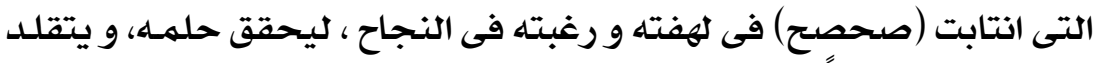

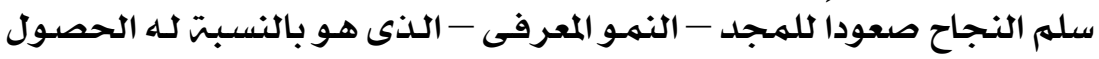
على السـاعتّ.

\section{(1. 1. الساعت}

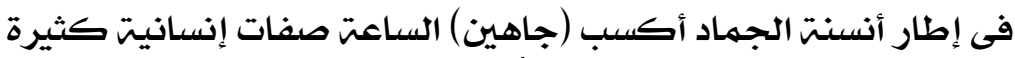

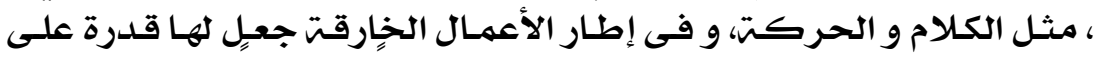

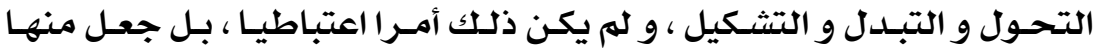

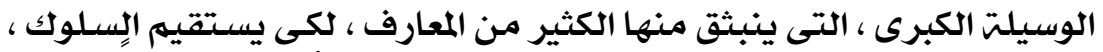

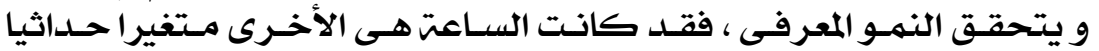

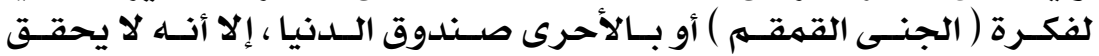

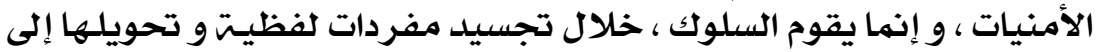

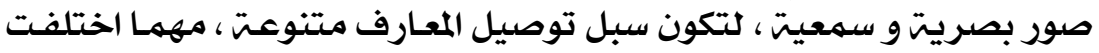
سبل التلقى .

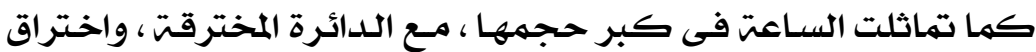

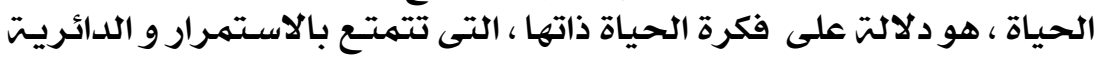

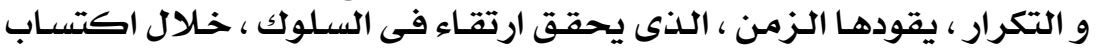

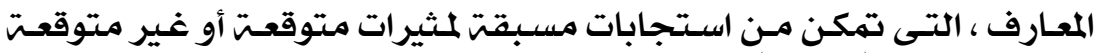

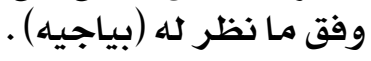

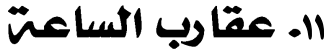

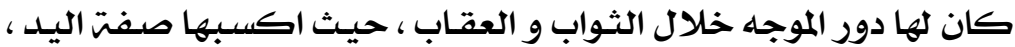

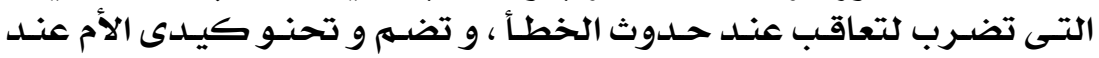
الشعور بالخطر و لطمأنينت أو لإِثابت .

\section{1r إش ומمس}

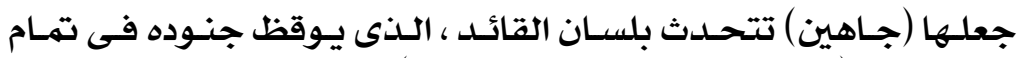

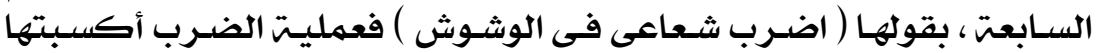

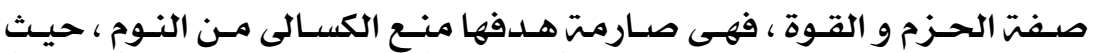

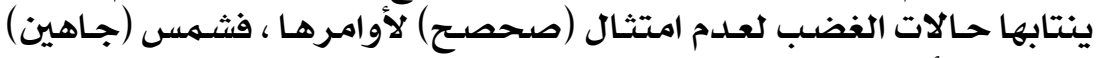

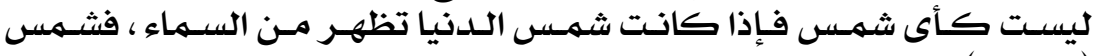

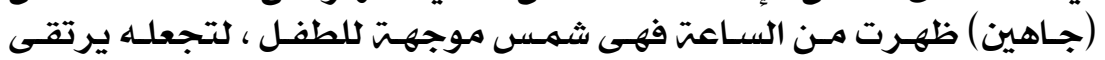


معرفيـاً ، خـلال معرفتهـ بـأن السـاعت السـابعت هـى وقـت الاسـتيقاظ للـذهاب للمدرستة.

جعل (جاهين) من صوته أداة لتنبيه (صحصد) ، ، (يلا أوام تلهم تلهم) كما ألها

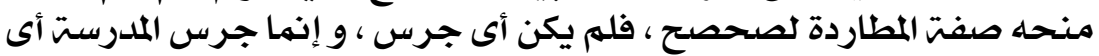

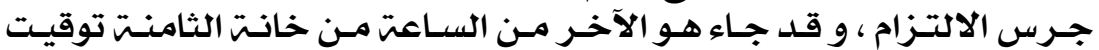

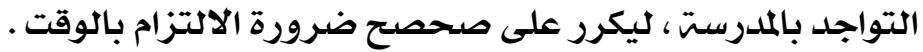

\section{عا. الدحذاء و وباطها}

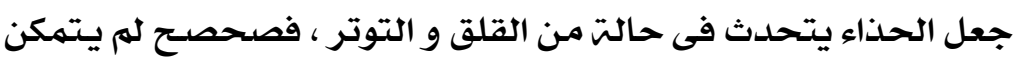

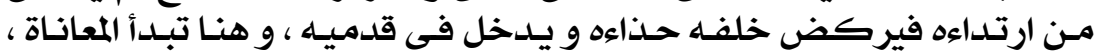

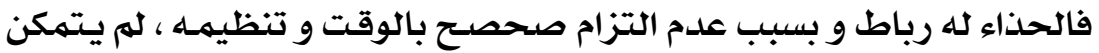

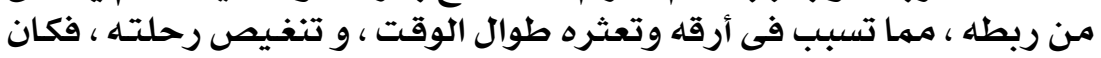

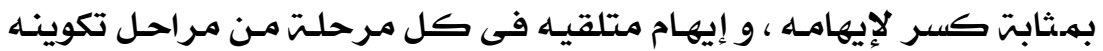

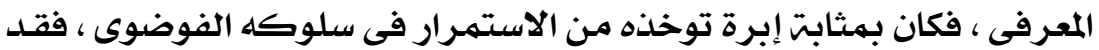

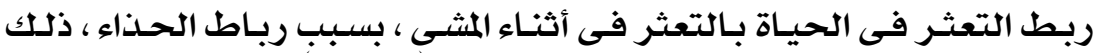

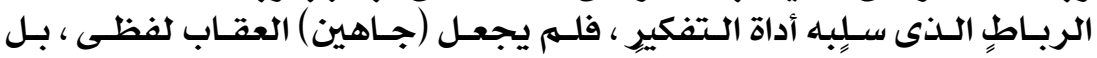

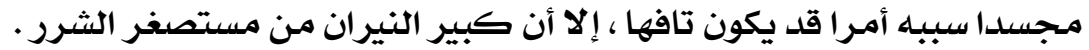

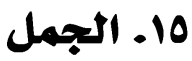

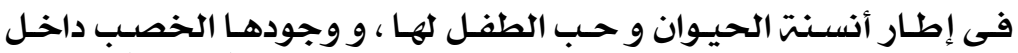

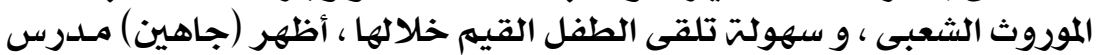

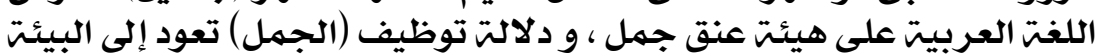

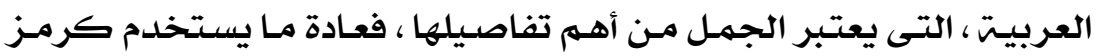

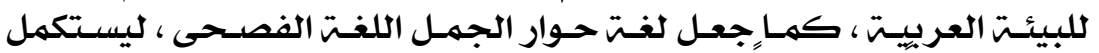

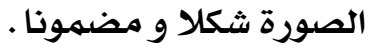

\section{1. - n أبو الهول}

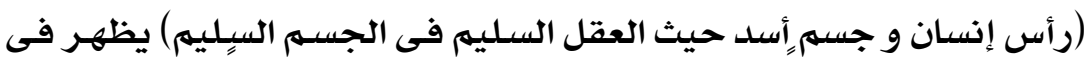

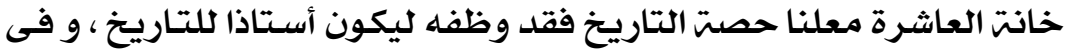

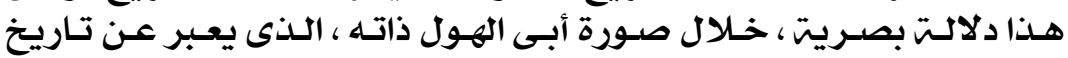

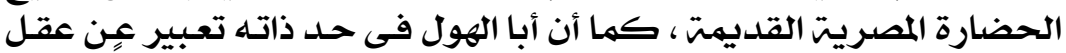

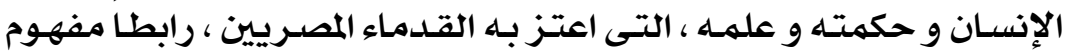

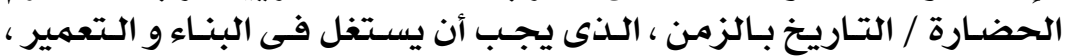

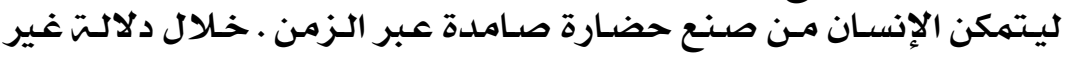


مباثــرة علـى بذــاء المعرفتر و تكوينهـا ، لينهــو الطفـل نهـواً سـليماً صـامداً كأجداده الفراعنت.

\section{V ا. زهرة حنك السبع}

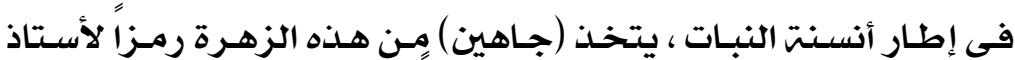

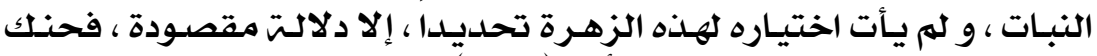

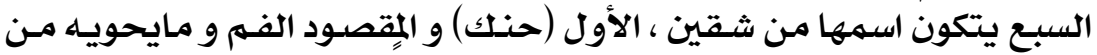

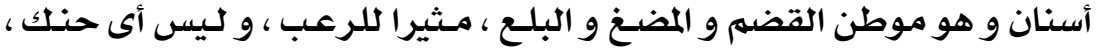

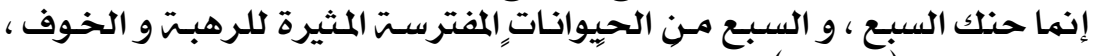

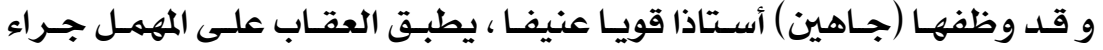

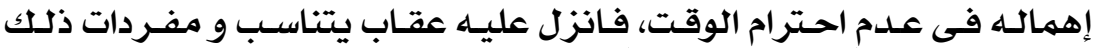

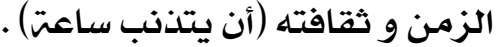

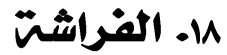

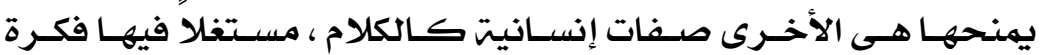

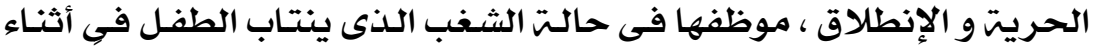

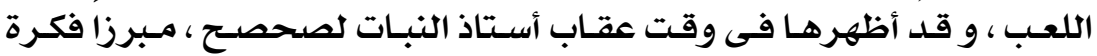

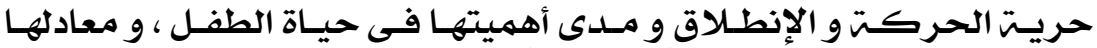

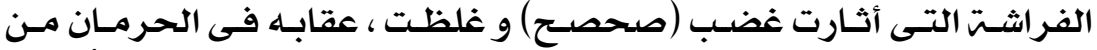

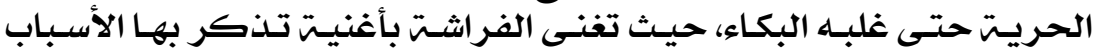

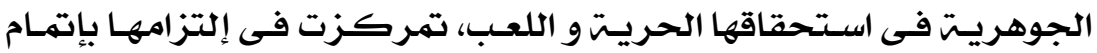
مراحل حياتها في أوقاتها المحلددة .

19. الشوكت

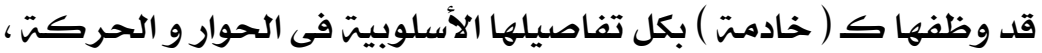

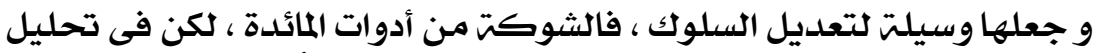

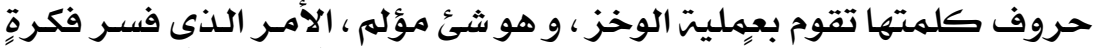

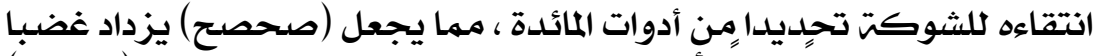

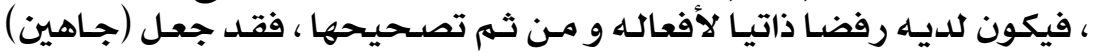

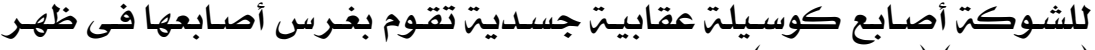

$$
\text { (صحصح) (إرفع إيدك) . }
$$

\section{•r. - علامات الحساب - البرتقال}

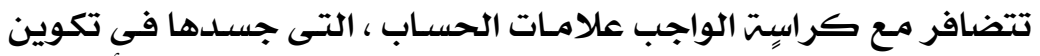

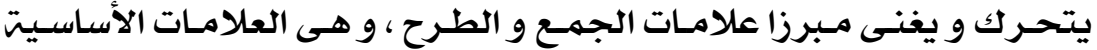




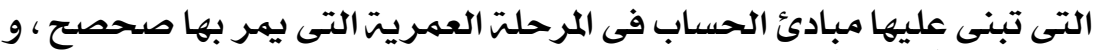

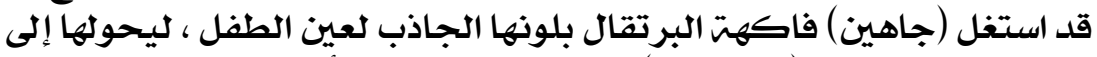

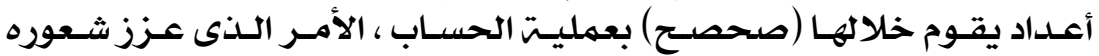

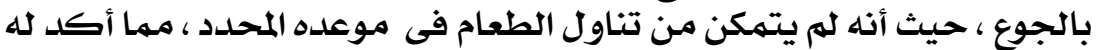

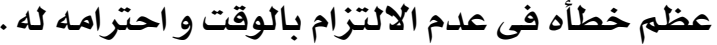

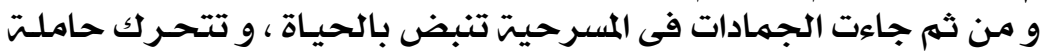

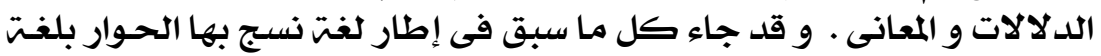

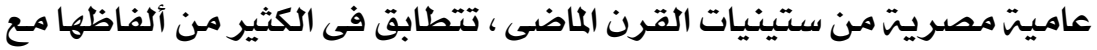

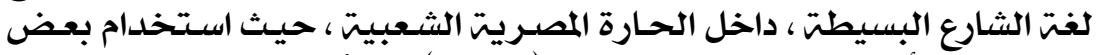

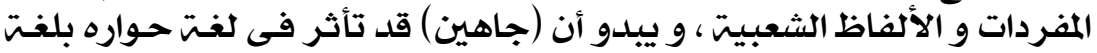

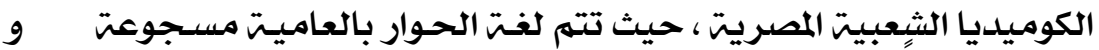

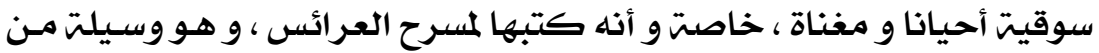

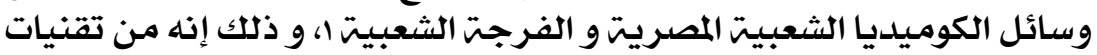

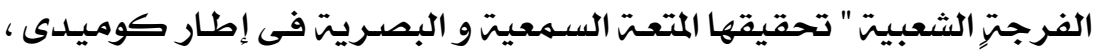

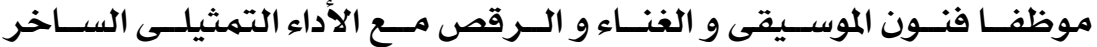

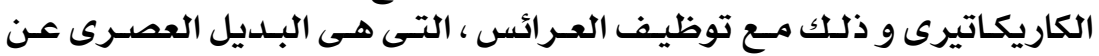

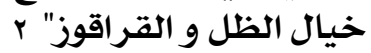

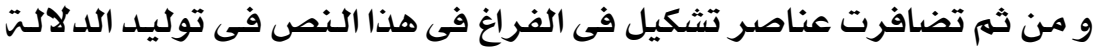

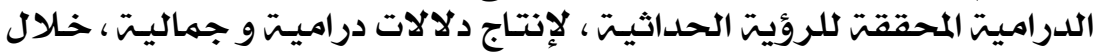

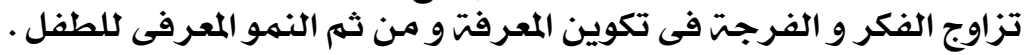




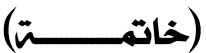

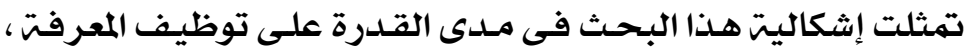

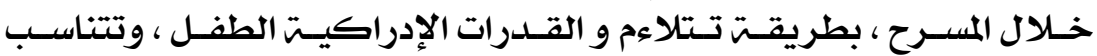

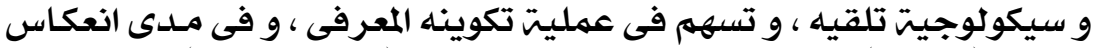

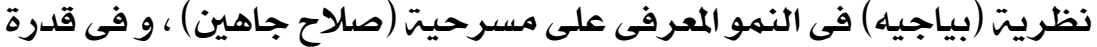

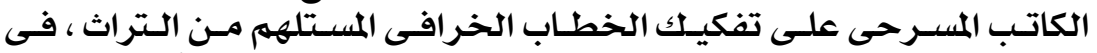

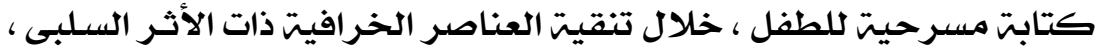

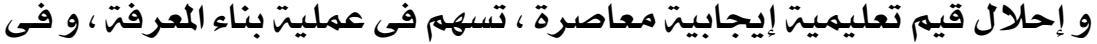

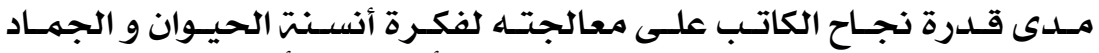

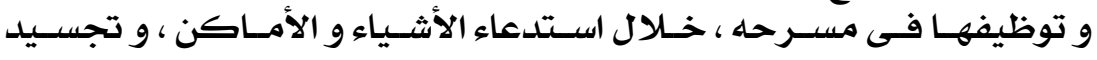

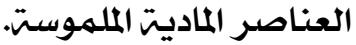

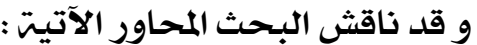
المبـحث الأول : أبثل

•نظريت (بياجيه) فى النمو المعرفى و قراءات الباحثين حولها.

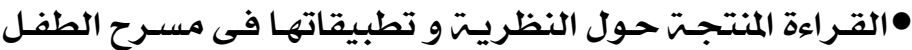

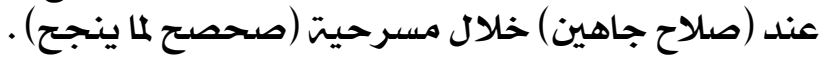

المبحث الثانى:

•دلالات التثابك بين التراث و الحداثت فى (صحصح لما ينجح) .

$$
\text { •البناء الدرامى و دوره فى تكوين البناء المعرفى . }
$$

أنسنت الحيوان و الجماد و توظيفها فى النص و دلالاتها .

$$
\text { و قد انتهى البحث إلى : }
$$

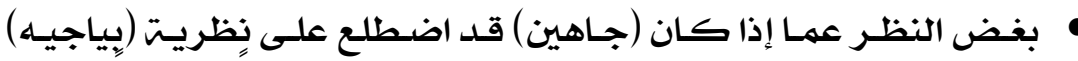

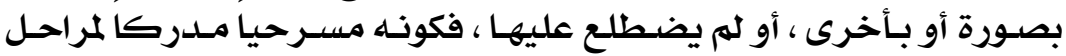

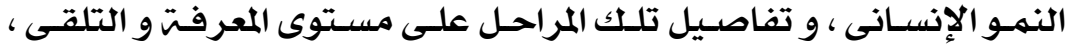

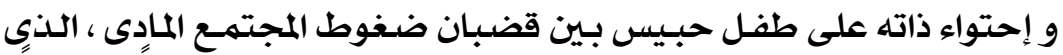

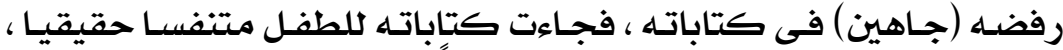

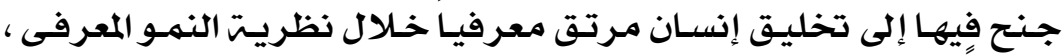

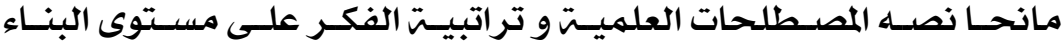

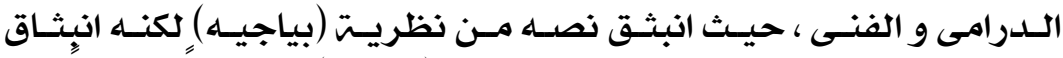

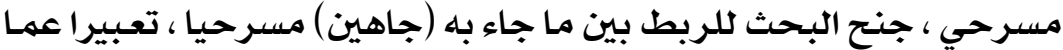

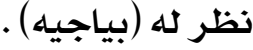

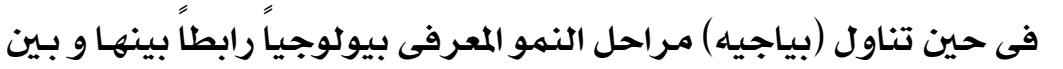

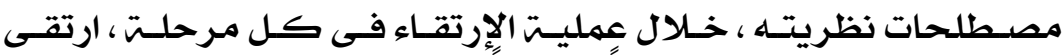

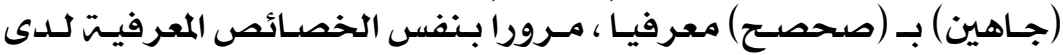




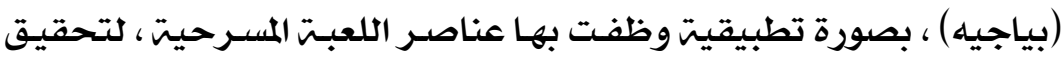

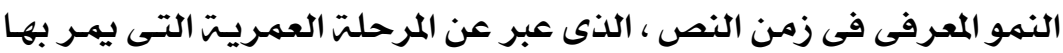

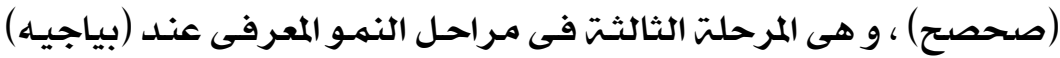

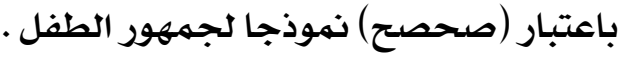

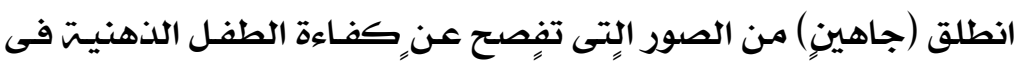

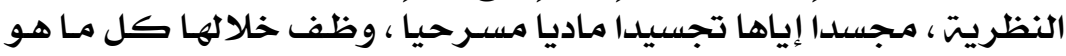

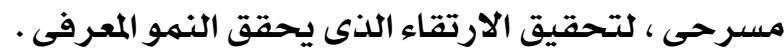

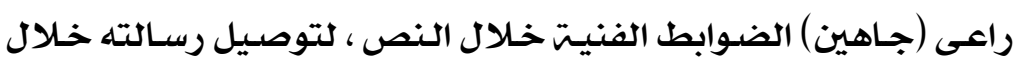

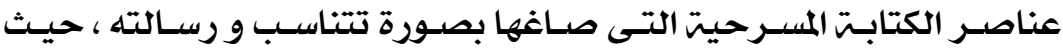

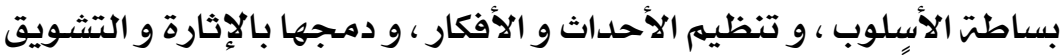

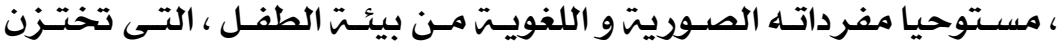

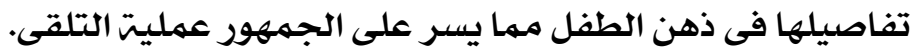

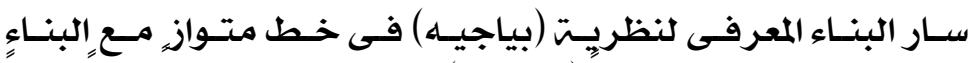

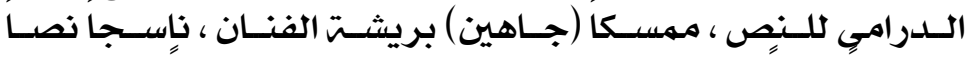

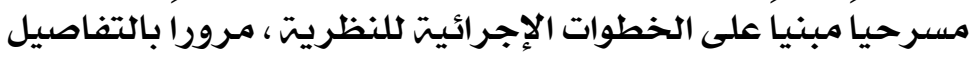

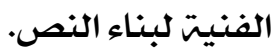

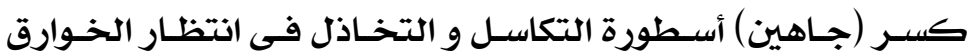

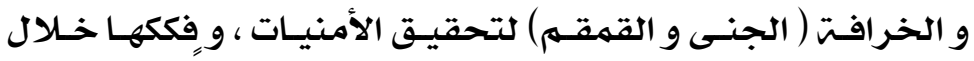

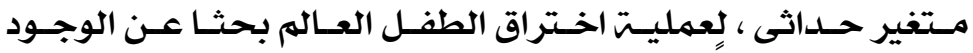

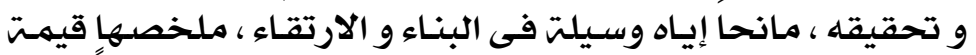

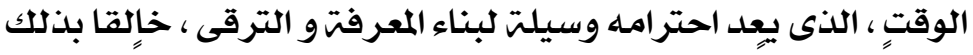

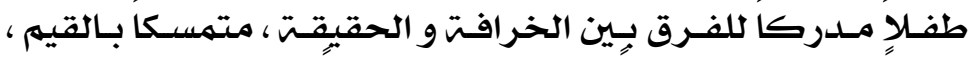

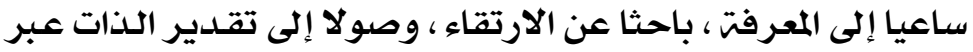

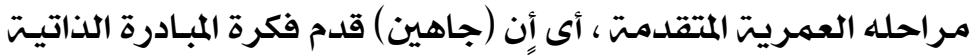

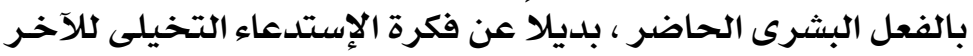

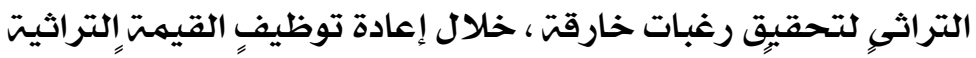

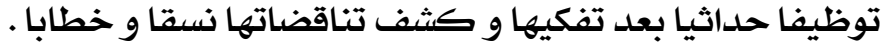

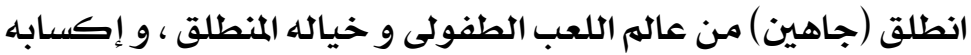

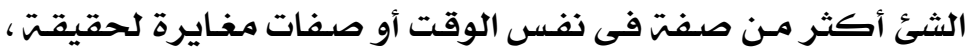

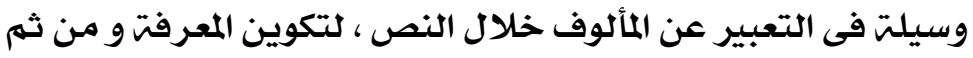

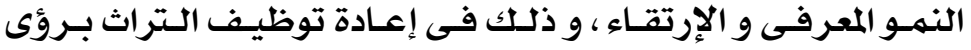

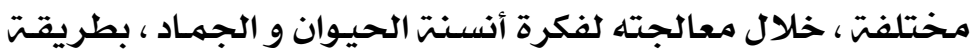

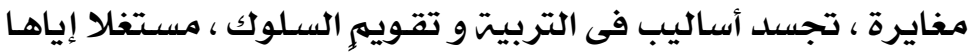

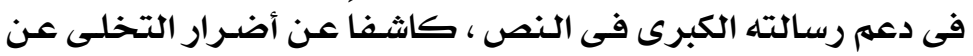




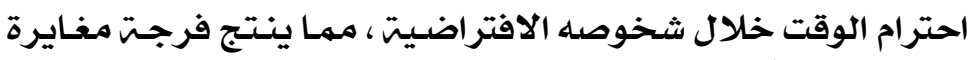

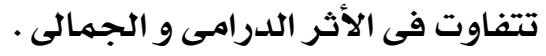

$$
\begin{aligned}
& \text { و أخيراً يوصى البحث : }
\end{aligned}
$$

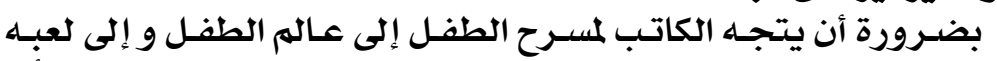

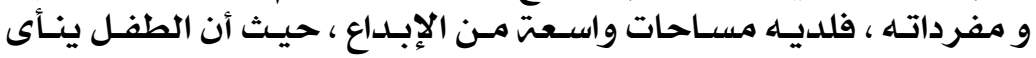

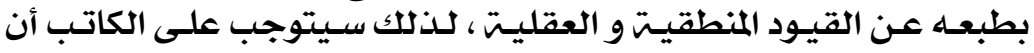

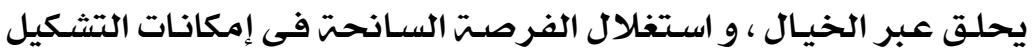

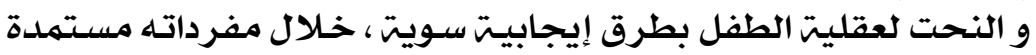

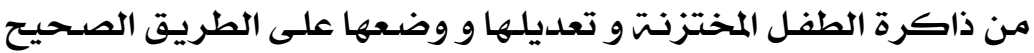

بهدف تحقيق النهو المعرفى . 


\section{المصادرو المراجع}

ا. أبو الحسن سلام (د) " الرفيق الخيالى و مسرح الطفل فى عصر العولمت "

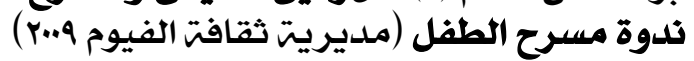

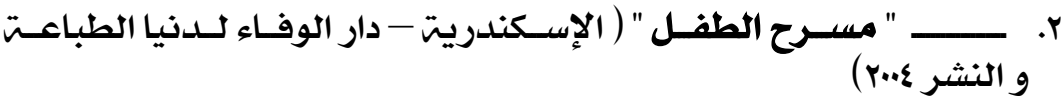

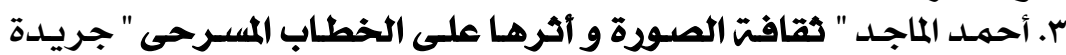

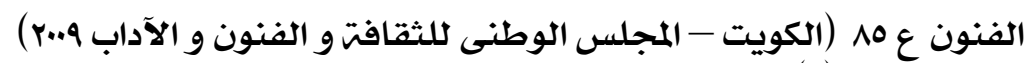

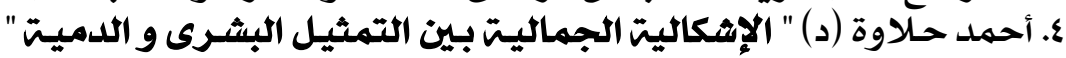

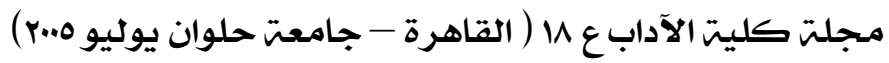

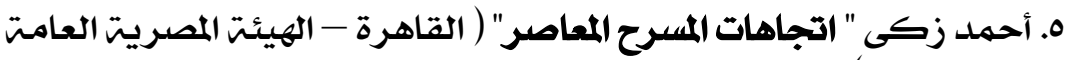
للكتاب 1997) 7. أحمد نجيب " موام فى بحر التراث " ( القاهرة - المركز القومى لثقافت

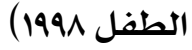
V. أرســو " فـن الثـعر " ت: حمـادة ابـراهيم ( القـاهرة - الأنجلـو المصـريت (191r

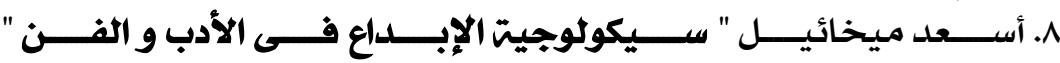

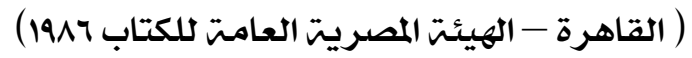

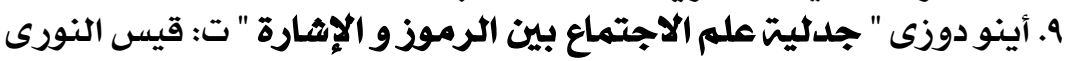

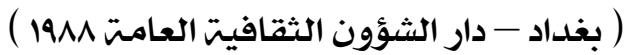

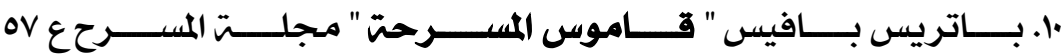

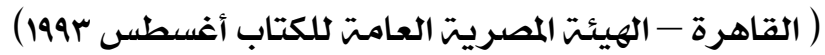

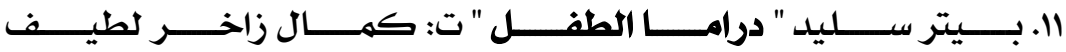

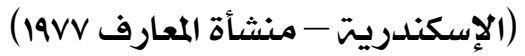

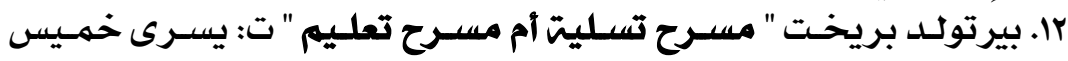

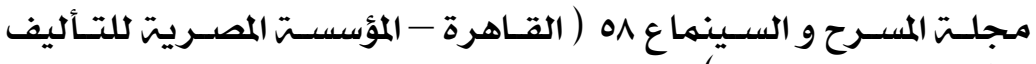

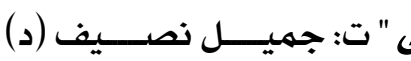

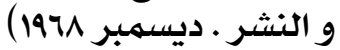

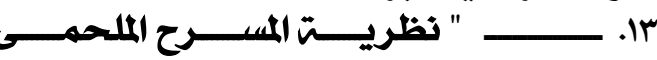

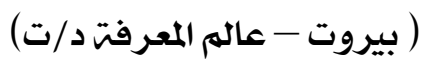

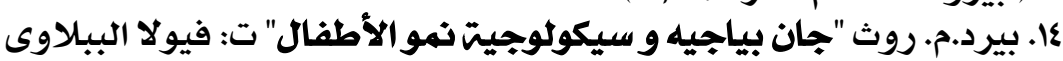

$$
\text { ( القاهرة - الأنجلو المصريت (19VV) }
$$

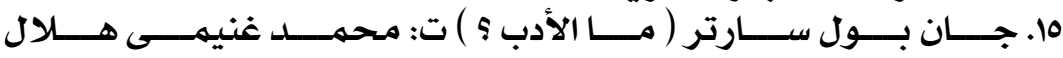

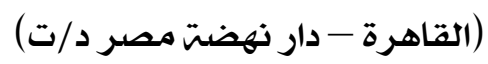

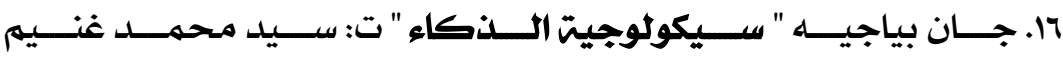

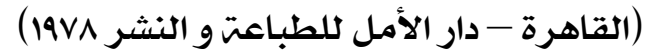

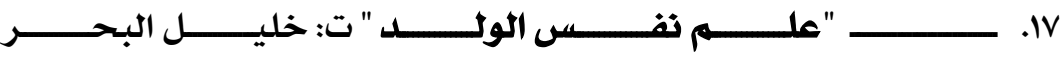
(بيروت - المنشورات العربيت (19Vr ) 
11. جـودت عـزت عبـد الهـادى " علـم النفس التربوى " ( عهـان - دار الثقافت

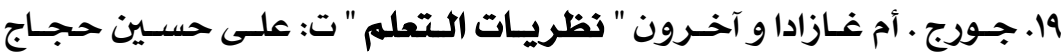

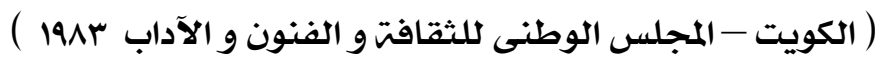

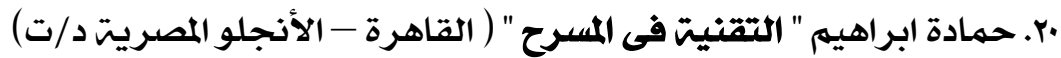

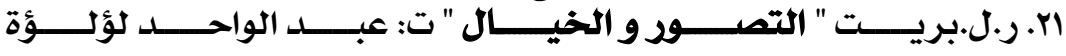

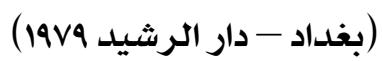

r.r. رؤوف محمهـود القيسـى " علـم الـنفس التربـوى " ( عمـان - مطــابع دار

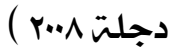

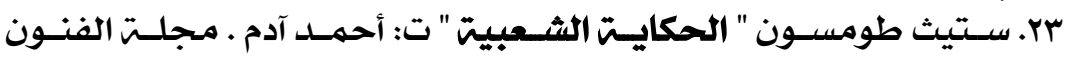

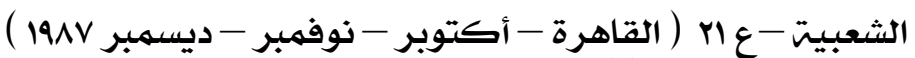

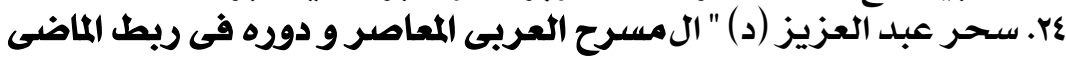

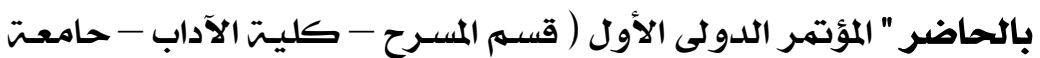

الاسكندريت مارس المونمر الـولي الإن

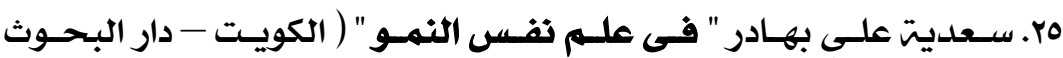

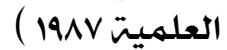

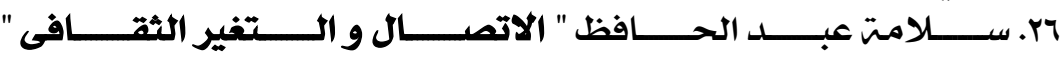

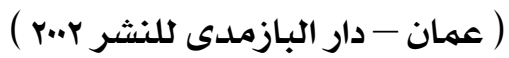

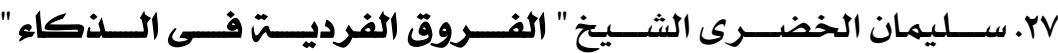

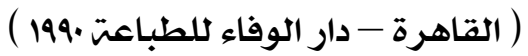

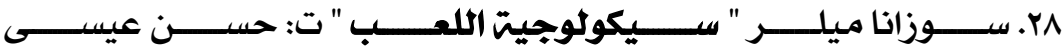

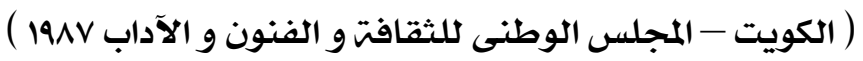

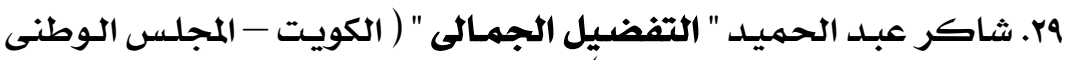

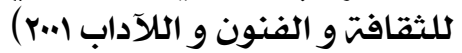

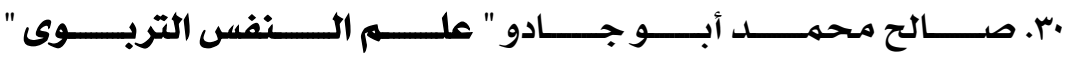

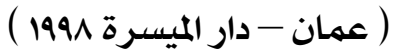

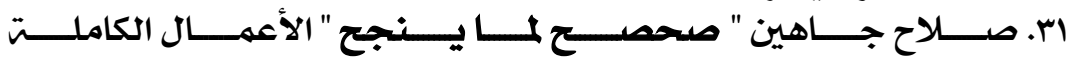

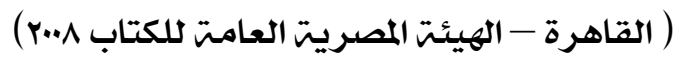

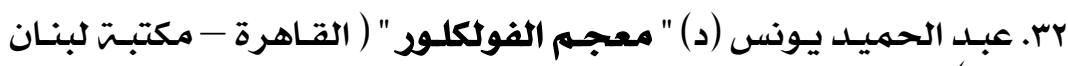

(1914r

rr. عبد المجيد نشواتى " علم النفس التربوى " ( الأردن - دار الفرقان 191911 )

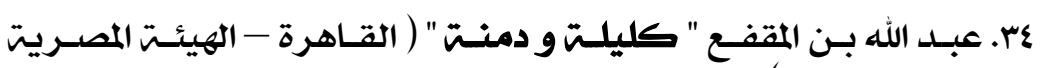

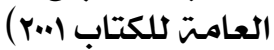

هب. عبلت عزمى " لعبت الطفل " ( القـاهرة ـ المركز القـومى لثقافت الطفل 


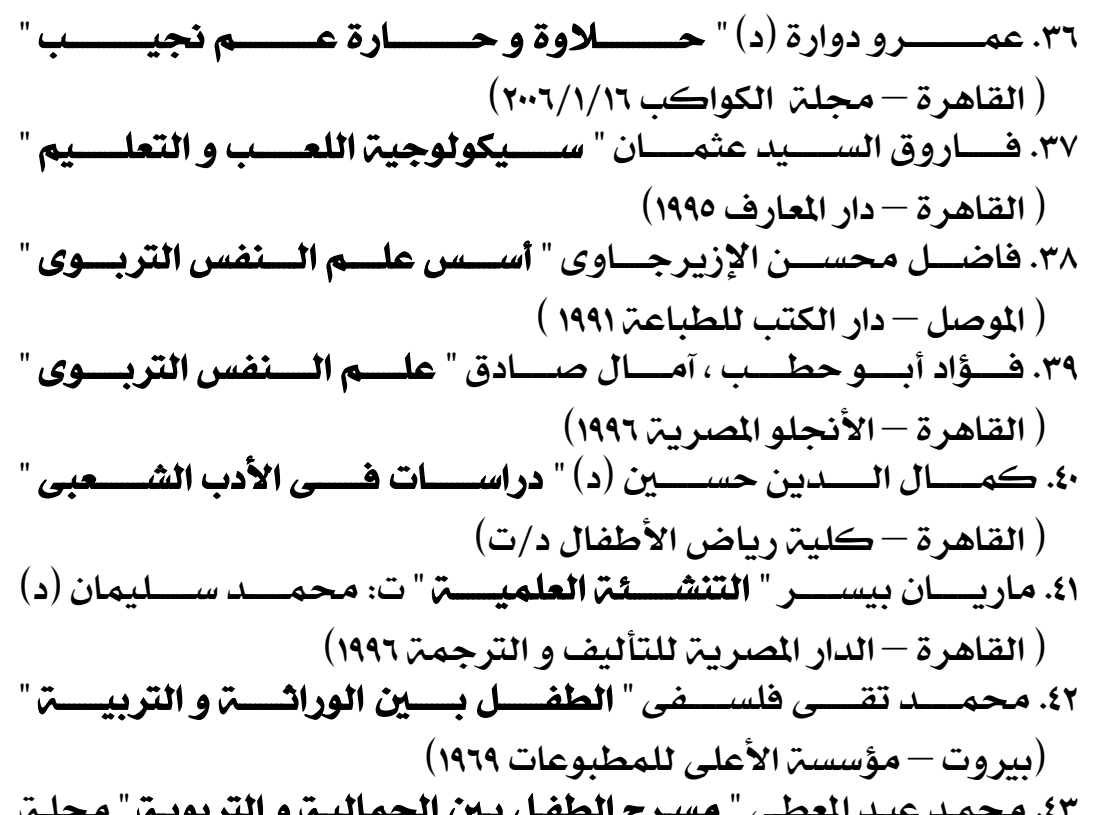

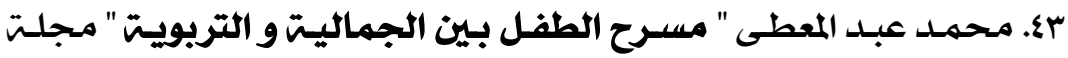

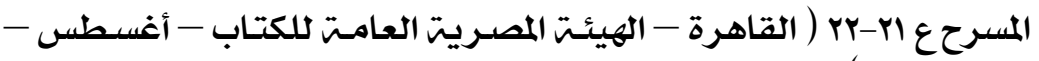

(199. سبتمبرح)

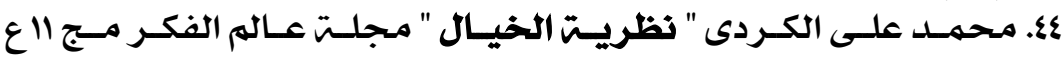

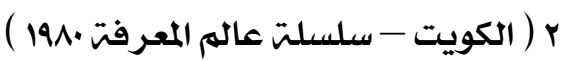

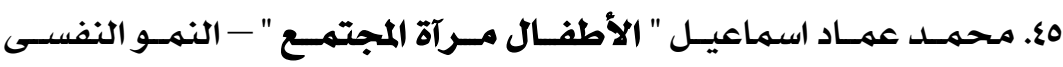

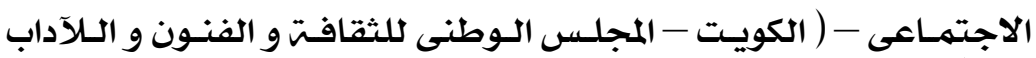

(1917

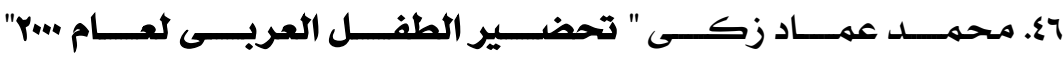

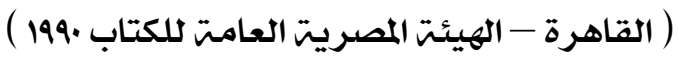

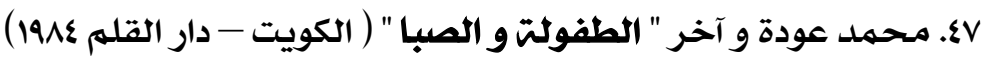

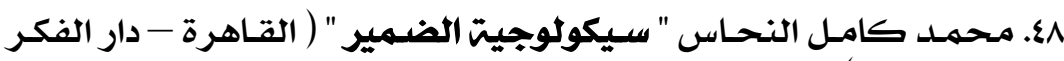

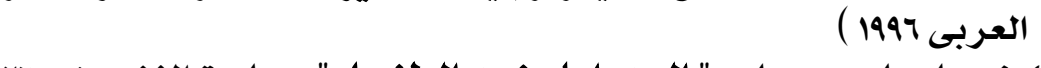

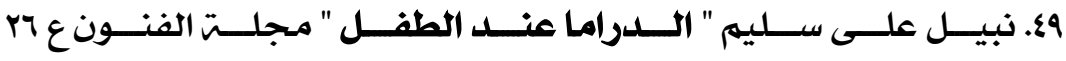

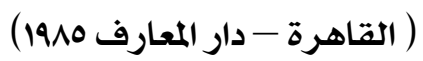

•0. ليونارد كابل برونكو " المسرح التجريبى فى فرنسا " تارئ يوسف اسـكندر

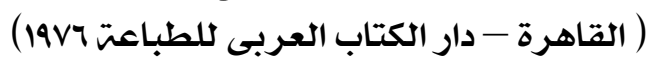

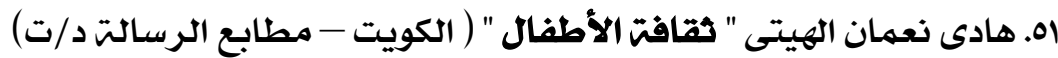

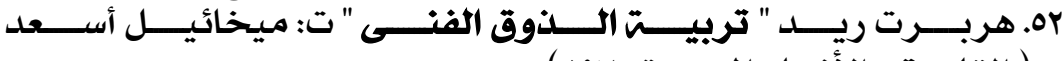

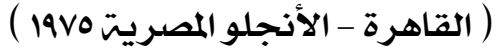

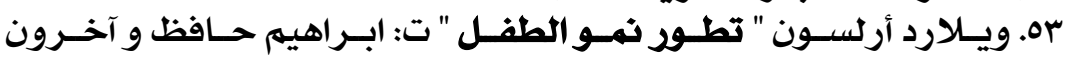

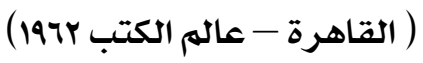


54.Aqueci,F. (2010).Ordine e Trasformazione : Morale ,Mente,Discorso in Piaget, Aciveale ,Roma : Bonanno

55. Baldwin,J.Jean Piaget(2005). In Key Thinkers in Linguistics and the Philosophy of Language . Retrieved Form

56. Gruber,H.E.Piage,Jean (1896-1980).in J.H.Byrne (ED.), Learning and Memory (2nd ed., PP.526-529). New York Macmillan

57. Mayer,S(2005). The Early Evolution of Jean Piaget's Clinical Methods History of Psychology

58. O'Donnell,A.,Reeve,J.,\& Smith(2009)Educational Psychology . Reflection for Action $\left(2^{\text {nd }}\right.$ ed)Hoboken,Wiley \& Sons 